
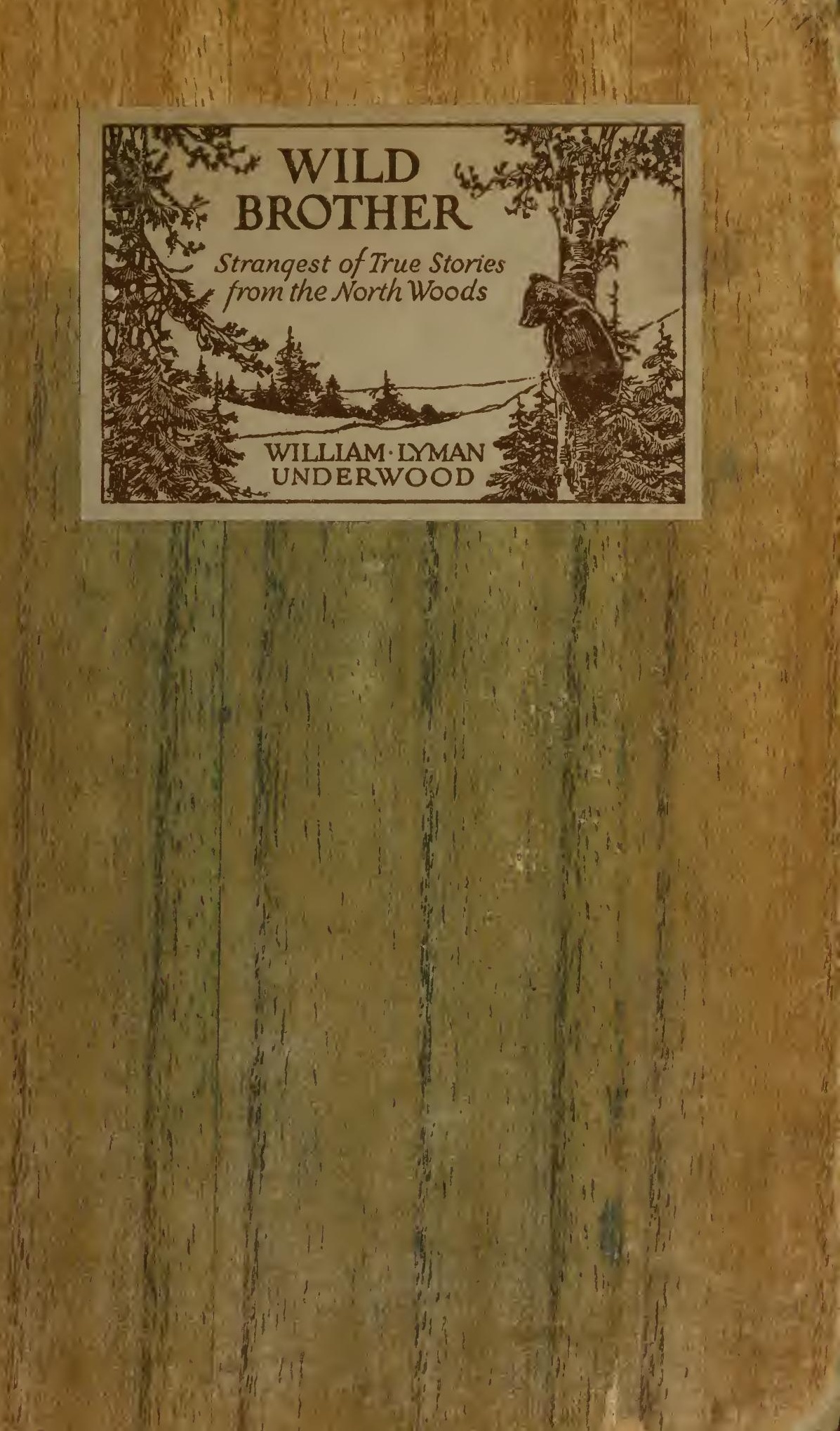

To Dear kite hmm with Jots of love and a Happy Birthday?

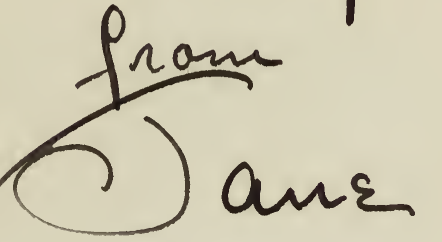

april. 18/23. 

WILD BROTHER 

Digitized by the Internet Archive in 2014

http://archive.org/details/wildbrotherstran00unde 


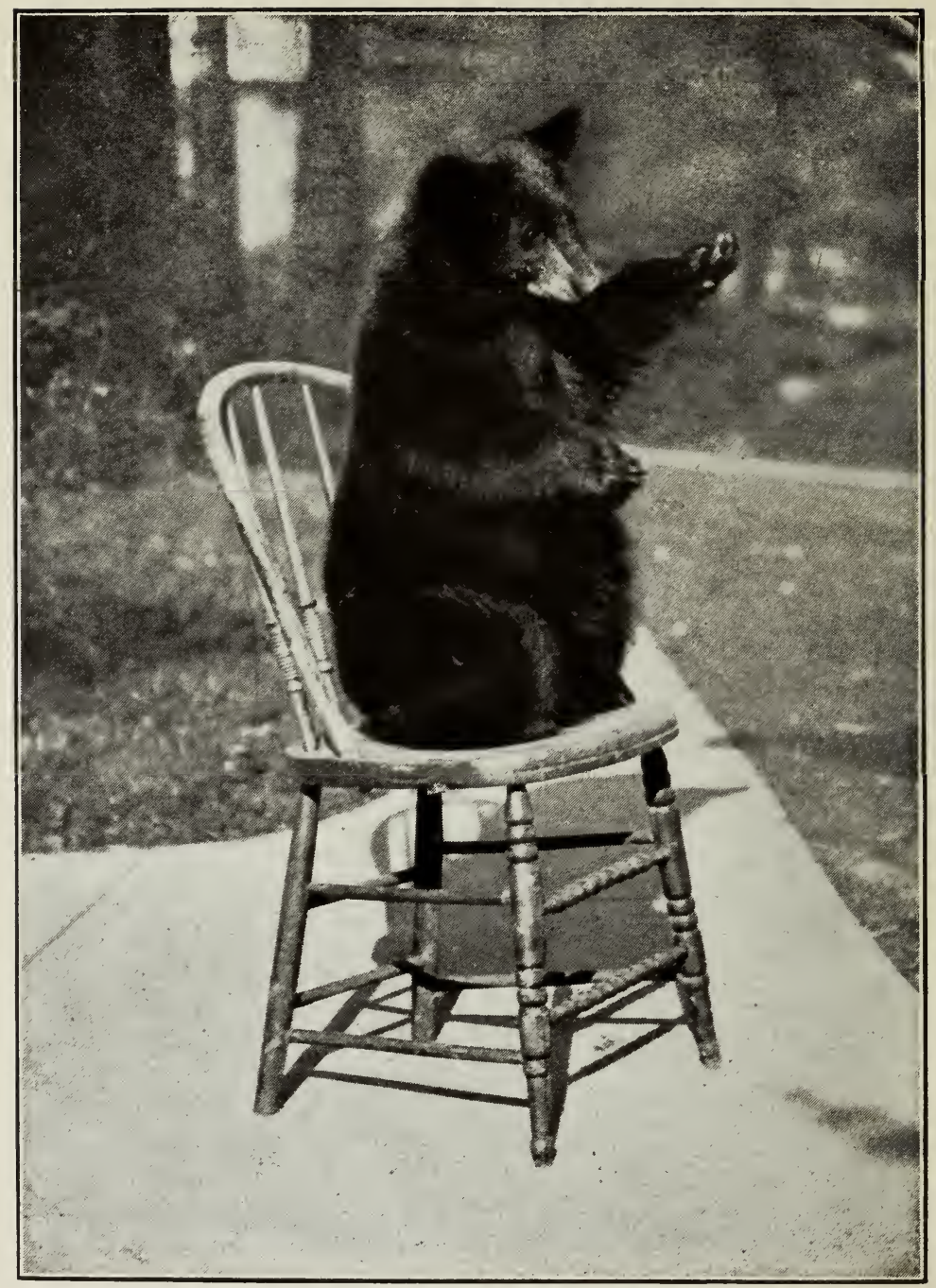

Bruno invites you to hear the story of his strange life 


\section{WILD BROTHER}

STRANGEST OF TRUE STORIES FROM THE NORTH WOODS

By

William Lyman UNDERWOOD

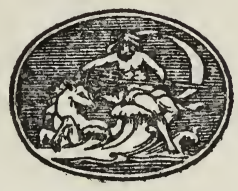

Illustrated from Photographs by the Author

THE ATLANTIC MONTHLY PRESS

BOSTON 


\section{Copyright, 1921 \\ BY WILLIAM LYMAN UNDERWOOD}

ALL RIGHTS RESERVED

First Impression, Nov., 1921

Second Impression, May, 1922 
$\tau_{0}$

Comrade

ever my helpmate and companion 



\section{CONTENTS}

The Start of the Trail $\quad . \quad$. . . . . I At Gordon's Camp . . . . . . . . I7

May-time in the Forest • • • • • 4 I

The Bear Makes a Journey • • • 53

Bruno in Belmont . • . . . . . 80

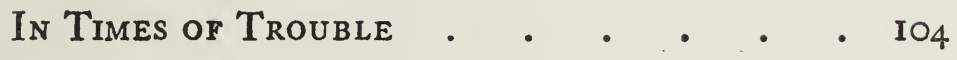

Bruno Must Depart • • • • • •

The End or the Trail . • • • • . 127 



\section{ILLUSTRATIONS}

Bruno invites you to hear the story of his strange

life . . . . . . . Frontispiece

The one-way road to Gordon's Camp . . . 6

Gordon's Camp was buried deep in snow. . . . I2

Mrs. Weldon and the children with some of the crew.

It was too cold for the baby . . . . I6

Mr. Underwood took this picture of Ursula and Bruno and me with my consent and I am glad to have him use it in this book . . . . 18

The den where the bear was born and the man who found him . . . . . . . . 22

Life in the deep woods agreed with Ursula . . 26

Bruno (weight two pounds) takes his first meal of prepared milk . . . . . . . 32

By this name the foster-sister of the bear was christened . . . . . . . . 36

Bruno (weight seven pounds) looking for sugar . 44 How much jam could he eat? They never had enough to find out! . . . . . . 48 The air was thick with the smoke of forest fires . 54 Bruno and his oldest sister on the day he left home 56 The cub liked to crawl inside and watch the children as if he were playing hide and seek . . . 56 
Bruno bids good-bye to Ursula.

The lake country of the St. Croix River - the end of

Bruno's first journey . . . . . . 64

Sometimes he could not wait for dinner to be served 66

The cub looks out on the wide, wide world . . 68

If we left the door unlatched, Bruno had no difficulty

in opening it . . . . . .

Caught in the act - an interrupted climb after the enticing bulb

Watching for his enemy, the dog

One of Bruno's wild relatives broke into this cask and

dipped the molasses out with his paw.

72

76

Each day we dropped downstream to wooded lakes

below. . . . . . . .

The author's home in Belmont - the "playground"
where Bruno grew up. . . . . . 80

He still insisted on feeding from the wooden trough 82 Bruno was willing to have his picture taken, but he wanted to examine the camera first . . . 82

He is astonished to see water running up hill . $\quad 84$ Who would n't like this on a hot summer day? $\quad 84$ Bruno is introduced to a new arrival in the family. $A$ moment after the picture was taken he kidnaped the "baby" and ran down the meadow 
Finally to escape pursuit he dropped his booty and climbed a ladder.

86

"Come on if you dare," his attitude plainly implied 90

For the first time in his life Bruno encounters a toad and-(See page 94). . . . . . 92

Bearlike he investigates by gently touching the visitor's back; whereupon - (See page 96) .

Much to the astonishment of the investigator the toad leaps over the saucer. An instant after this picture was taken the bear dashed madly away as if he had seen an apparition from the lower regions

Once a week his weight was recorded . . . Ioo Football was a favorite sport with these friends . Ioo Bruno falls on the ball. First down, ten yards to gain

He could cling to a tree like a squirrel . . .
The bear always treated Foxy with the greatest gentleThe bear always treated Foxy with the greatest gentle-
ness, even when the dog bit his paws . IO6
There he sat in the warm water with the soft clothes of
the week's wash comfortably settled beneath him IIO
A hard tomato thrown accurately excited Bruno's The bear always treated Foxy with the greatest gentle-
ness, even when the dog bit his pares .
There he sat in the warm water with the soft clothes of
the week's wash comfortably settled beneath him
$A$ hard tomato thrown accurately excited Bruno's The bear always treated Foxy with the greatest gentle-
ness, even when the dog bit his paws .
There he sat in the warm water with the soft clothes of
the week's wash comfortably settled beneath him
A hard tomato thrown accurately excited Bruno's 104 IO4 wrath - and he chased his assailant down into the meadow .

IIO

II4 
A sport that he enjoyed was to climb out on the small limbs

He threw his arms round my waist and drew me closely to him. A moment after this picture was taken a sudden rage seized Bruno and he nearly put an end to the story . . . . II6

He had evidently come for an afternoon call and was now waiting for tea to be served. . . . II8

Not since the day when he reveled in the sugar barrel had he sniffed such delicious odors . . 120

He was glad to see me and touched my arm in greeting. . . . . . . . . 122

When full grown, Bruno was an enormous bear weighing about four hundred pounds . . 126 


\section{WILD BROTHER}





\section{CHAPTER I \\ THE START OF THE TRAIL}

I SHOULD hesitate to tell - with the expectation that it would be accepted as the truth - the true story that I am now to relate, were it not possible for me to illustrate it with photographs that I myself have taken.

It is a story of human kindness and compassion that has seldom, if ever, been exceeded, and of incidents, humorous, pathetic, and surprising, that had their beginning in a log-cabin far back in the forest. Even to-day, many years after the first event, this train of strange incidents has not come to its end. The story chronicles the life of a black bear's cub, which, having lost its mother when only a few days old, was saved from starvation by a kindhearted woman, who adopted it into her family and, when its life was all but gone, nursed it and cared for it with her own baby.

From time immemorial we have had handed down to us myths, legends, and stories connecting the lives of the lower animals with those of human beings. Ancient history gives us the story of Romulus and Remus, the founders of Rome, who, it is said, as infants, were left in the desert to starve, and were saved from that tragic end by a 
she-wolf, which nursed them to vigorous health with her own young.

Greek mythology gives us the touching story of Atalanta, daughter of Iasius, who was abandoned and left to die in the wilderness. She, too, was saved by one of the lower animals, for a bear nursed her and brought her up with its cubs.

Kipling in his "Jungle Book" has immortalized Mowgli, the man's cub, who fled from the wrath of Shere Khan, the tiger, and took shelter in the den of a wolf, and was brought up with her young.

Many such stories have come down to us out of the past, but has anyone ever heard of the reverse of these stories? Does history record an instance where a woman, to save the life of a helpless starving animal, has taken it into her family and brought it up with her baby? I think not.

Such a story was told to me one evening in midwinter, by the station agent in a little village in northern Maine, where, with Mrs. Underwood, my comrade on all journeys short or long, I was waiting for the midnight train to take us back to Boston. That afternoon we had driven out from my camp at the head of one of the Schoodic lakes, twenty-five miles away. It had been a cold hard pull, over heavy unbroken roads deep with two feet of newly fallen snow. In the comfortable glow of a red-hot stove we sat in a circle, the railroad 


\section{THE START OF THE TRAIL}

men, some villagers, Comrade, and I, enjoying the warmth of the room, discussing the weather, and telling stories of the woods and the lumber-camps.

"Say, Bill," asked the agent, "have yer heard about the doings out at Gordon's Camp? No?

"Wal, yer know that woman, the wife of the cook that Gordon hired last fall. Wal, they say she's bringing up a bear with her baby; sleep together, they say, in the same cradle.

"Yer don't believe it ?" he inquired of me, as he saw the incredulous look on my face. "Wal, you walk up the road to the store. Gordon's father, he keeps it. You ask him. Young Gordon was out day before yesterday and told the old man about it. He'll tell you it's the truth."

We had a long wait before train-time, and the incident was so unusual that I bundled in to my big overcoat and went out seeking information. The storekeeper was locking up for the night when I arrived; but as soon as he learned my errand, he let me in and gladly told me all he knew about the bear that was being brought up as a child.

"Jim was in a hurry when he come out the other day," said he. "Took No. 37 down river to Bangor. He did n't have time to say more'n that they'd found a bear's den with a cub in it. A cute little feller; Jim said it beat all how small he was. He cried just like a baby when they hauled him out on 
the snow. Yes, they say the woman's going to fetch him up with her baby. Don't know what the idea is, but that's what she's doing, all right. I'll find out more about it for yer when Jim gets back."

Here was an astonishing incident, if it was true. I had, however, no time to verify it. Gordon's lumber-camp was twenty-three miles back from the village, with only a rough logging road leading to it, and I must be at home next day.

Before I left, the storekeeper promised to get the whole story for me, and to obtain permission from his son for me to visit the camp if I could manage to get away for another winter trip to the woods.

Not long after my return to the city, however, a discouraging letter came from Maine. The bear had been sold, the storekeeper said, though the person who had bought it had not as yet come to take it away. If there was time in the interval before the cub left the lumber-camp for me to come down, he would write again.

I had given up all hope of being able to verify my extraordinary bear story when, a week later, there came another letter, saying that the adopted cub was to stay on for the present at least, and that I could come as soon as I wished.

Immediately I wrote the proprietor of the village hotel that I should arrive on the morning train on 


\section{THE START OF THE TRAIL}

February twenty-first, and asked him to have a man with a team meet me at the station and be ready to start at once for the woods, so that I might return to the village in time for the midnight train back to Boston. Soon after I had sent this letter, however, some urgent matters of business came up, obliging me to take the trip two days earlier than I had originally intended. So I sent a telegram to this effect.

The morning of February nineteenth, 1903, found me standing in the snow outside a lonely railroad station. It was long before sunrise. The conductor had swung his lantern, and now the twinkling red lights on the rear of the train that had brought me were vanishing in the distance. I was alone beneath the stars. Three feet and more of snow lay level on the ground. It was bitter cold, with the mercury far below the zero mark. For a while I stood awaiting the expected sled from the hotel ; in absolute silence, save for the distant, everfainter rumbling of the departing train, I listened for the jingling sound of sleigh-bells which should come from the direction of the village; but none came. Evidently my plans had miscarried. Events move slowly in the Maine woods, and dates and appointments are sometimes forgotten or fulfilled at leisure.

When my feet had begun to grow cold and my 
ears numb with the biting frost, I reluctantly picked up my suit-case and camera material, and trudged along through the snow to the village inn, luckily not very far away. The door was locked, but a light shining through a side window showed that someone was stirring inside. Through the frost-coated glass I caught a glimpse of a frecklefaced, tousle-headed boy, busily engaged in sweeping the office floor. A knock on the window-pane and a shout soon brought him to the door.

"Why, Mr. Underwood!" he exclaimed in astonishment, as he saw me kicking my frozen toes on the door-sill. "We warn't expectin' you this mornin'."

"Didn't you get my telegram saying I was coming to-day ?" I asked.

"Yep," he drawled, "we got your dispatch, but yer letter come the day after and yer letter said yer would n't be here till the day after to-morrow, and yer see that ain't to-day. But come on in and git warm," he added. "Breakfast'll be ready by half-past six."

It was then half-past five. The big balloonshaped corrugated stove shone red with heat. I sat down within its warm glow and, leaning back in my chair, with my feet on the encircling iron fender, I was soon dull with drowsy comfort, pleasantly dreaming of the little bear in the warm lumber-camp. 


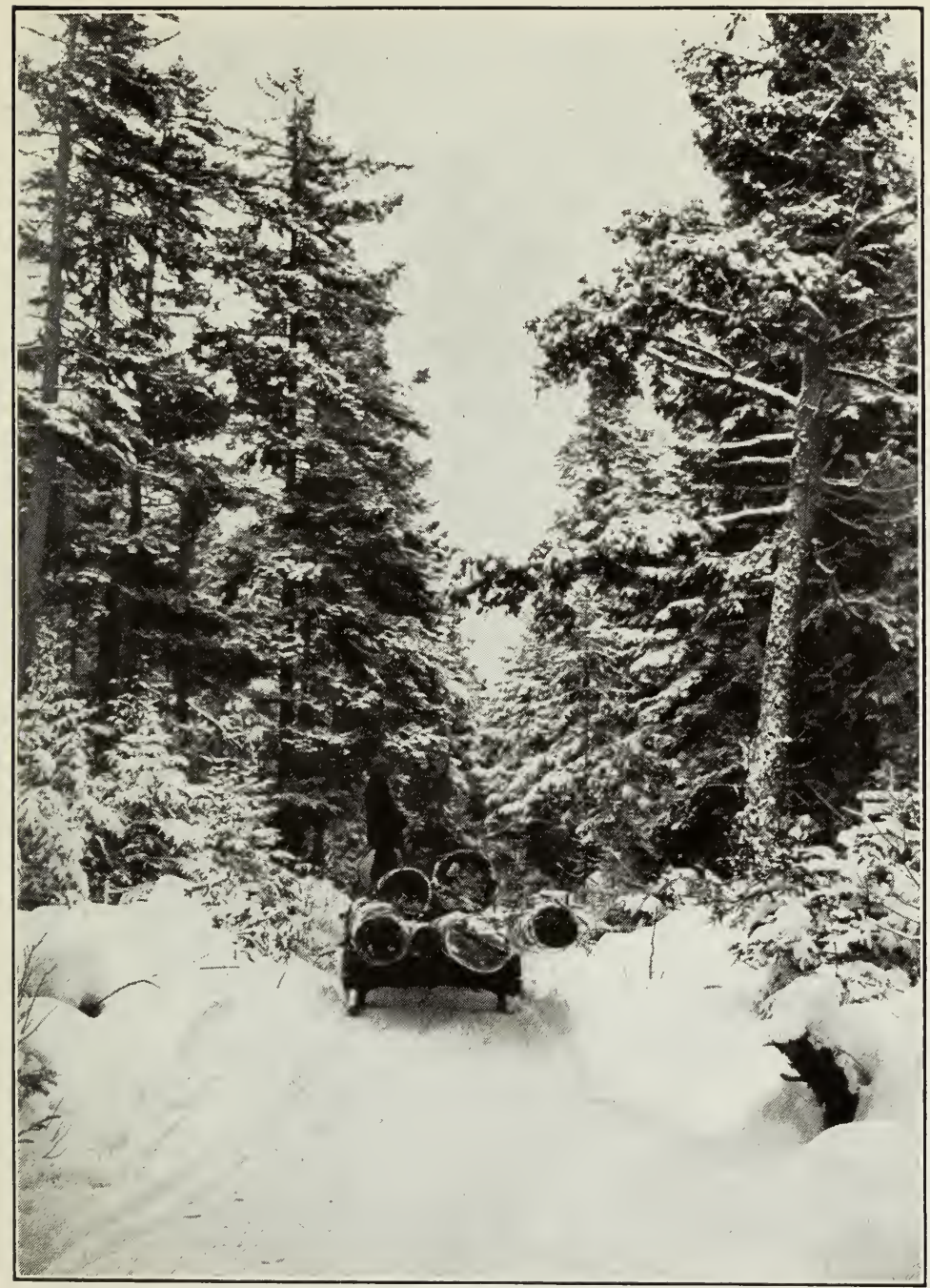

The one-way road to Gordon's Camp 



\section{THE START OF THE TRAIL}

The closing of a door woke me from my reverie, and there beside me stood a tall, meek-looking individual, as yet but partly dressed. He was clothed above in a thick red flannel shirt, and he stood in an attitude of supplication, with his long arms outstretched toward the genial stove.

"Jim," he wailed, "didn't yer get my writing telling yer to have hot water in my room at six o'clock?"

"Yep, I got yer letter," the boy replied indignantly, "but yer did n't say whether yer wanted it at six o'clock last night, this mornin', or ternight."

"Wal, can I have it now? I want to shave," said the countryman.

"Yep, yer can if it ain't friz," said Jim.

At breakfast-time, day was just coming, but as yet no steps had been taken to outfit me for my journey into the woods. Life slows down in backwoods New England towns in the winter, and to get along with comfort one must accept conditions as one finds them. Manners and customs cannot be changed for the moment.

When I returned from the dining-room, half a dozen villagers were gathered round the hospitable office-stove, discussing the stranger within their gates. A violent argument was in progress. It seemed that there were three lumber-camps in 
operation back in the forest, and whether Gordon's was the first, the second, or the third on our road, was the cause of the dispute.

Another, and to me a more serious, discussion now arose. There were two different roads that led into this lumbering region. The teamster who was to act as my companion and guide had never been over either of these trails. In the argument the natives were divided into two hostile groups. One group favored the lake route; the other maintained that this trail was impossible, inasmuch as no teams had crossed the ice since the last fall of snow. We might get to the lake all right, but it was seven miles across it, and after we got out on it, we could not tell where to get off. New snow had hidden the sled-tracks.

The opposition very loudly favored the logging road. That was more direct and easy to follow the whole way. The lake advocates admitted this. "But what'll he do when he meets any sleds?" demanded one big chap. "Yer know as well as I do, Dan, there ain't a single turnout fer ten miles on that loggin' road. It's a one-haul road. They'll all be comin' out this mornin' and heavy loaded, too. There'll be some cussin' and swearin' if he gits in their way. He can't git by in that narrow road any way you figure it; if he tries to turn out he'll be stuck in the soft snow." 


\section{THE START OF THE TRAIL}

With much interest and considerable apprehension I listened to the controversy, which had grown quite violent and now threatened to end in a fight. Finally I stepped into the midst of the wranglers and ended the disturbance by announcing that the lumber road was my choice. At least, it started in the village and ended in a definite place; and if I could not get off it, for the same reason, I could not get lost. At all events, I was not looking for trouble until it came to me.

An hour later my outfit, a fine pair of heavy bay horses drawing a two-sledded pung, drew up in front of the house; and in a few minutes we were off, in the midst of a chorus of shouted warnings and advice from the villagers. It was after ten o'clock, and I could now see that it would be impossible for me to get back in time for the night train home. However, I had come a long way for that bear story, and I was bound to get it if I had to spend a week in the woods.

For three miles our road led through the sparsely settled district, and we sped briskly along on a firm track. The white blanket of snow stretched level and smooth over the tops of walls and fences. The big brass bell on the end of the pole throbbed its ever-musical beat with the regular stride of our steeds, and the steel-shod runners creaked loudly as they moved on the up grades of the hard-packed 
snow. Presently we came to the logging road, and leaving the main thoroughfare, pulled out to the left. Following the road across an open field, we were soon in the forest.

The lane through the timber was so narrow that frequently the ends of the whiffle-trees hit the treetrunks as we passed along. The inner wood on many of the trees showed white where the bark had been torn away by frequent scrapings. What should we do when we met the lumber-haulers bound out for the settlement?

I found myself listening constantly for the sound of approaching bells, and not long had $I$ to wait. As we swung round a sharp turn, past a large boulder that lay directly in our path, we saw, some distance ahead, gliding smoothly down a gentle incline, six heavily laden sleds. All came to a standstill on the level ground at the foot of the slope. Little puffs of white mist rose intermittently on the cold air, from the nostrils of the panting horses. The foremost teamster left his stand on the "rolling bar" in front of the logs and, whip in hand, came running toward us. Trouble seemed imminent.

"Hello, Fred," he shouted, in keen astonishment. "Where in thunder are you aimin' for on this road at this time o' day? Did n't yer know this is a one-haul road? What are you goin' to 
do now? The snow is four feet deep in here."

One by one the rest of the crew gathered about us - rather a rough-looking lot at first glance, with cloth and fur caps pulled down over their ears and the collars of their coats turned up. Icicles hung from the heavy moustaches on some of their faces, while swinging jaws and numerous and increasing spots on the snow indicated a heavy consumption of tobacco.

At the first opportunity Fred, in reply to their many questions, told them he was bound for Gordon's camp; that his passenger was going in to see the bear-cub. To my surprise and relief, it seemed to be a magic word, the open sesame to our dilemma. Hard looks at once changed to smiles.

"Wal," the spokesman announced between puffs from a newly lighted black clay pipe, "we'll see what we can do. Yer won't have much more trouble if yer can get by us. There's only four more teams comin' out."

Luckily for us, we had stopped at a point where the openings between the timber were quite wide. No trees would have to be cut for the passing; the depth of snow was the only difficulty. It took us half an hour, however, to overcome this obstacle. Briskly the men set to work tramping back and forth by the roadside just ahead of us. Though their feet were not on the ground, the snow was 
up to their waists. But finally they trod it down with their heavy stamping shoes.

Our horses strained their shoulders into their collars, plunged out to the side of the road, and stood belly-deep while one by one our new friends crawled by.

Fortune favored us that day, for on one of the sleds as a passenger was a young man who had left Gordon's camp early that morning. For two dollars and other valuable considerations he agreed to show us the way in to the bear, one of the other considerations being that he should be taken back to the village that night. The boss had given him a few days off, and he had not been at home for a month.

Within half an hour we met the other teams. Again mention of the little bear helped us. When the men learned of my errand, they willingly set to work, though we were not so fortunate in our meeting-place, as several trees had to be cut and hauled out of the way before the snow was tramped down and we could pass.

Without our pilot we should have had hard work in finding our way to Gordon's camp, as there were many roads that led to the right and left from the main line. We made good progress now over the smooth, beaten track. There is great exhilaration in a sleigh-ride over a lumber road in mid- 


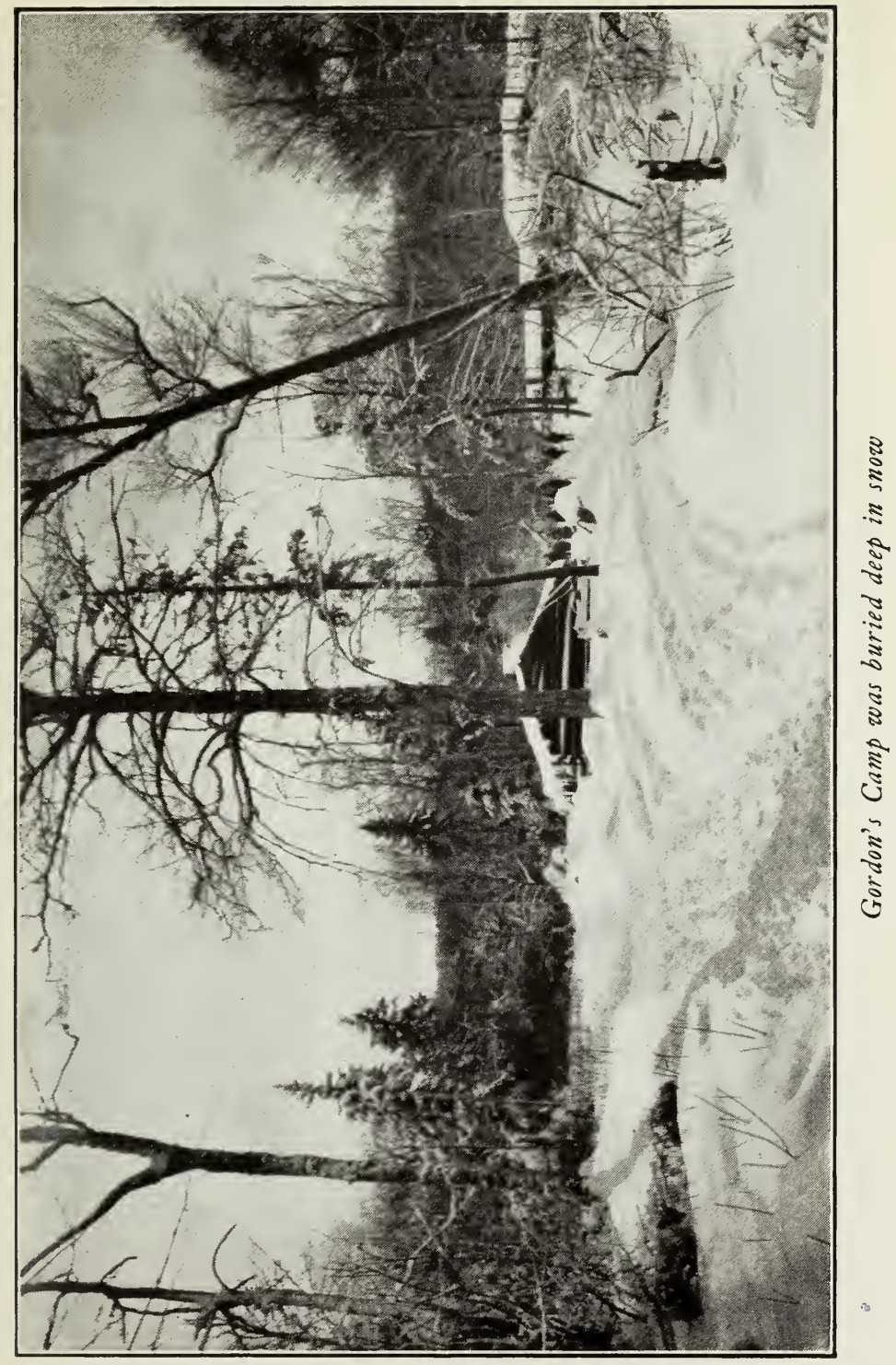





\section{THE START OF THE TRAIL}

winter. The forest trees keep off the chilling winds, and all sounds are hushed in the soft mantle of snow, without which progress would be impossible. In summer there is no passing, for the surface of these narrow openings between the trees is broken by rocks, holes, and stumps.

At noon we reached the first camp, and received a hearty welcome from the men who had come in for lunch. We joined them at the long white boardtable, which was abundantly supplied with wellcooked simple food. Hot tea or coffee warmed the inner man. Doughnuts just out of the pot of boiling lard on the stove, with gingerbread and applesauce, ended the feast.

We tarried yet a while in the gentle warmth of the place. Outside the men were grinding their axes in preparation for the afternoon's work. My driver lent a hand and helped the cook and cookee wash the dishes, while he gave them the latest news of the village. The cook had heard about the bear at Gordon's, and thought the woman stood a fine chance to make a good deal of money when, later, she sold it to some circus company. "But I'll tell you what," he volunteered, "I'd never let my woman do a thing like that. She would n't want to, anyhow. Say," he questioned, "ain't it a queer thing, any way you figure it?"

"I don't know as it is," Fred replied. "She's an 
awful kind-hearted woman. She'd look after anybody that was ailing. You know two of them children of hers is adopted. She took 'em because their mother died and their father could n't look after 'em."

That afternoon we had no further trouble about meeting teams. There were plenty of turnouts all along the road. From this district the logs were being hauled down to the frozen surface of a lake, and the sleds were going and coming at all times of the day. We could hear the clang of the big bells before the teams came in sight, and always had time to haul into a turnout so that they could pass us.

For a mile or more before we reached the lake, our way led through a dense cedar swamp, and here in the thick growth deer, yarding for the winter, had tramped regular paths through the deep snow. The thicket provided them with shelter, while moss and bark and tender twigs of the young growth gave them food. As we drove along we counted five; they seemed not at all disturbed at our presence.

A little farther we came to the lake, where the teamsters were unloading their logs, the booming of which we had heard long before we reached the shore. Hauling round the timber as it lay spread out over more than an acre, we headed for the 


\section{THE START OF THE TRAIL}

centre of the lake, and were gratified to discover that out from the edge the wind had swept away the snow, giving us a smooth road for our progress.

In the distance, on the farther shore, we saw the smoke of a fire; and as we reached the other side, we came upon a man who was fishing through the ice. With a long heavy chisel, he had cut several holes through the two feet of frozen surface. Leaning over each opening was an alder branch, from which a bit of fish-line hung down in to the dark cold water. On an old pine-stump close beside his brushwood fire, and within easy sight of all his lines, sat the fisherman. Any movement of a telltale alder gave immediate notice that the hungry fish were biting.

The staple food of a Maine lumber-camp is baked beans and pork, and on every bill of fare, if they had one, this article would appear at least once a day. But frequently it happens that some delicacy of the locality will vary the monotony. One of the lumber-camps was to have lake trout and landlocked salmon for supper that night, for our fisherman had been in luck. Several good-sized fish lay, frozen stiff, on the ice.

Not only fresh fish, but often good tender juicy steak, is put upon the lumber-camp table. If your lumberman should be working alone in the forest, and a deer should charge upon him, he would 
not stand still and allow himself to be bitten. No, he would surely defend himself like a man, and with his axe he would stand the animal off, and even kill it if necessary; and on the menu, if they had one, "wild lamb" would be featured. If you should examine the dressed carcass, you might find a mark that looked suspiciously like a bullet hole. Of course deer are not supposed to be killed in the winter-time; but a hungry man must protect himself from harm, and in those days, nearly twenty years ago, deer were very plenty and withal very ugly, so ' $t$ was said - by the man who was hungry for good red meat.

Late in the afternoon, when we came into the clearing of Gordon's camp, the place at first seemed deserted; not a soul was in sight. The snow was piled high up to the eaves of the log cabins, but a thin wisp of blue smoke curling from the top of one of the stovepipe chimneys gave evidence that someone was at home; and as I got out of the pung, a pleasant thrill of anticipation came over me at the thought that I had reached my journey's end, and should soon discover how much truth there was in the extraordinary story that at first had found me incredulous. 


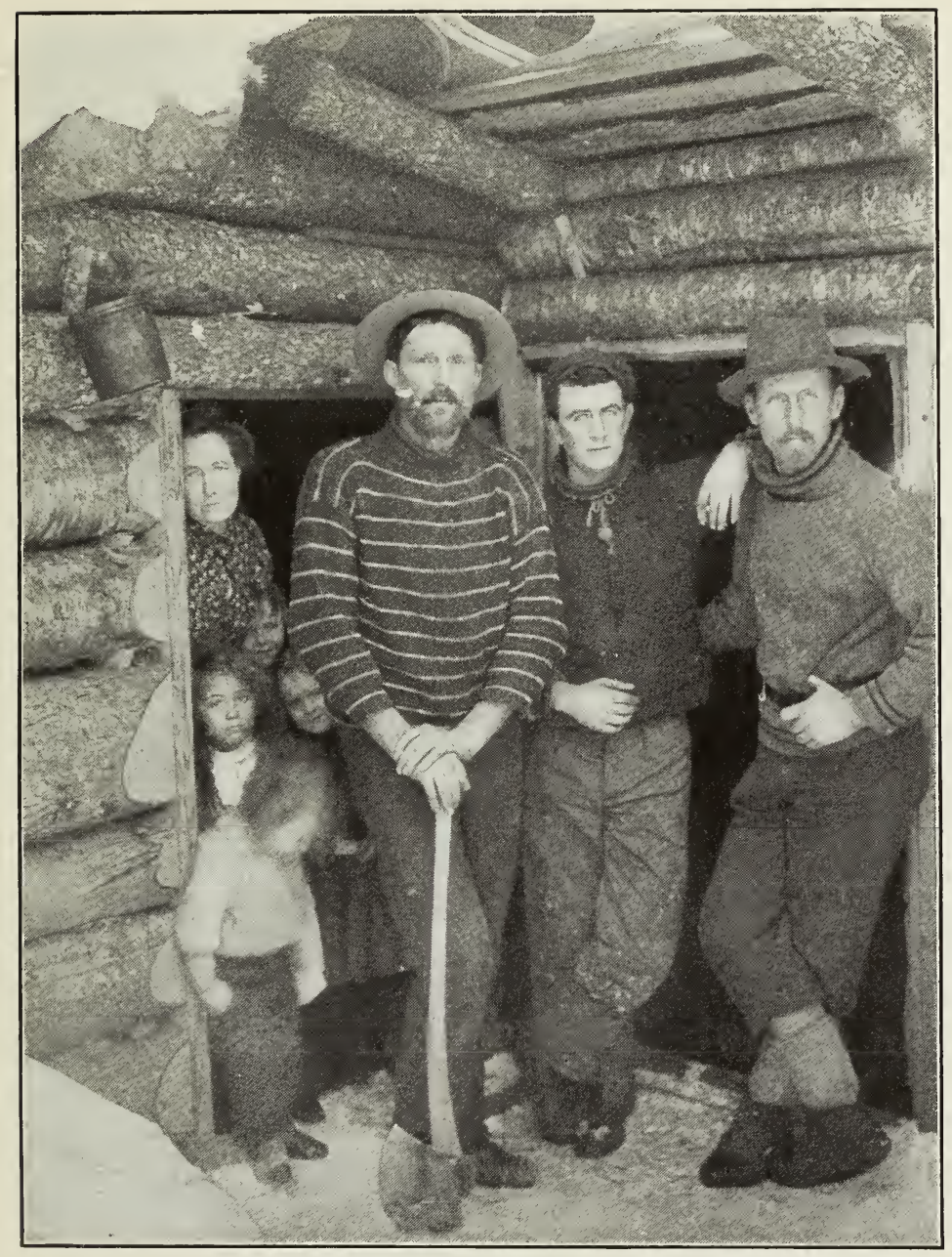

Mrs. Weldon and the children with some of the crew. It was too cold for the baby 



\section{CHAPTER II}

\section{AT GORDON'S CAMP}

WHILE the men were unhitching our horses, I knocked on the door of a log-cabin that adjoined the main camp. It was opened by a kindly faced woman about forty years of age, bearing a little child in her arms. She smilingly bade me enter, and motioned me to a seat on a bench beside the stove.

Four children, two boys and two girls, all seemingly about the same age, stood silently by while we talked. My first inquiry, after I had told who I was and explained why I had come, was to ask how the little bear was getting on. At my question one of the boys reached behind the stove and drew out a small shallow box, lined with deerskin. I now saw, curled up in its centre, almost hidden from sight in a nest of clean rags and bits of cloth, a tiny black animal. It could not be a bear! I looked again in great astonishment, for it seemed not much larger than a big gray squirrel! Now it moved, and began to whine and wag its head. Thrusting its little nose up and down, it made an appealing, plaintive, almost human call.

"Bruno is hungry, mother," said one of the children." 
"Will you excuse me, Mr. Underwood?" the mother asked, as she took the little creature from its bed. "He's real hungry and I have n't fed him since noon," she added.

As he felt the warm hands of his benefactress about him, there came a comfortable soothing tone in the little creature's complaining, and a few minutes later his murmuring ceased altogether as, gently moving to and fro in her rocking-chair, the kindly mother, with her back toward me, fed her foster-child.

The simplicity of it all - the crooning baby now in its cradle with one of the little girls rocking it, the other children playing about the primitive logwalled cabin, with its crude but ample home-made furniture - impressed me deeply. The room was redolent with the woodsy smell of timber; the afternoon sun shone through the window and lighted up the rough but clean plank floor. It all seemed so homelike and natural.

Many questions crowded all at once into my mind; but before I could ask them, there were voices outside, the latch was lifted, and the cook, the woman's husband, came into the cabin. He was a tall stalwart man, with a frank and honest face. After his wife's introduction, he greeted me pleasantly and explained that it would be impossible to put all of us up for the night. The men's 


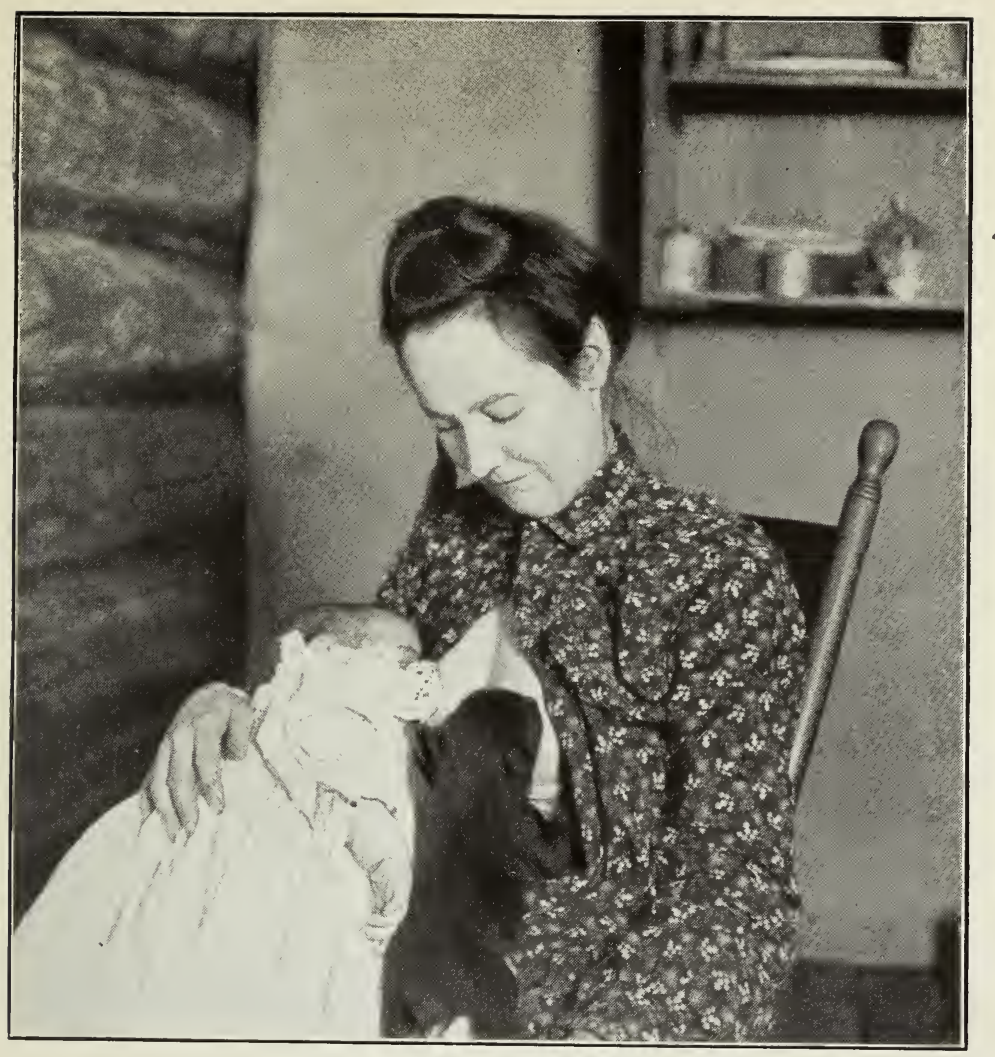

Tr 2 Unclerwad took this pictire of Arsula and Bruma and me with my consent and $I$ am glad to harce him use it in this book. Brumvis Faster mother 



\section{AT GORDON'S CAMP}

quarters were small, and every bunk was taken. If I myself wished to stay, perhaps one of the men would share his bed with me. It was also out of the question to accommodate the horses. The hovel, as the backwoods stable is called, was full; and with the temperature far below zero, it would be impossible to stand the animals outside during the night.

After a hasty supper, my teamster and our guide said good-bye and started back to the settlement. It was to be a moonlight night and they would have no trouble in getting out. My driver promised to return for me next day if no storm should come up in the meantime to block the roads. I had come a long way for this bear-story and I did not intend to go home without it.

At sundown the men came in from their work. Your lumberman has but few idle moments in his programme; he is up before dawn, and, as soon as it is light enough to swing an axe, begins his day's work. An hour off at noon, and then till sunset his labor goes on.

The biggest man in camp offered to share his bed with me, and it was after midnight before we retired. I was an eager listener to many backwoods stories told that evening round the ramdown stove. Once there came an interruption. I could hear the wailing of the little bear in the woman's quarters. 
The voice was soon quieted, and the men told me that Mrs. Weldon was feeding the cub. Weldon, I may say now, is not the real name of this kindhearted woman, but it will serve to identify her throughout this narrative and will make it unnecessary for me to reveal her own equally good American name, which, because she shuns publicity, she prefers to have remain unknown.

Now I learned for the first time the truth about the bear-how it happened that Mrs. Weldon took him in. It is unusual for a woman to have anything to do with a logging-camp; few of the wives whose husbands work in the woods ever see the winter quarters of their men. All winter long the lumberjacks are away, of ten not returning until the snow has gone, in the spring. It so chanced, however, that Mrs. Weldon's husband was a good' cook, and backwoods cooks are in great demand. In the fall of the year, when the lumber boss offered him a job at good pay, he at first refused it, saying that he did n't care to leave his wife and the five children back at home. But Gordon, who wanted a cook badly, suggested that he bring the wife and children with him, and occupy a cabin adjoining the camp. The bargain was made, and Mrs. Weldon with the five little ones - two of them adopted and all under five years of age moved back into the forest twenty-three miles from her home village, where through the winter snows, 
had they needed the services of a doctor, it would at times have been extremely difficult to get one. Her heart was brave as well as kind.

One day in January, when a crew of swampers were clearing away the timber and brush near the camp to make a new road, they began to have trouble with their horses. The animals acted strangely every time they approached a certain place just at the foot of a small ridge. Whenever the horses reached this spot, they reared and plunged and snorted with fright, and it was only by force and much persuasion that the men could keep them in the open way.

That evening, back at camp, the men told of the unusual behavior of the horses. Weldon, the cook, who was something of a hunter, suggested that there must have been a bear somewhere about, for a horse always acts in this way when in the vicinity of one of these animals.

The idea was ridiculed, for everyone knew that no bears would be roaming around at that time of the year. But the cook kept his own counsel, and next day he went out to the ridge to investigate. In a short time he made a discovery. At the foot of a huge dead pine tree he noticed a small hole in the snow, rimmed with ice and frost. He knew pretty well what had made it, and with his snowshoes he began to dig.

When he reached the ground, he found a large 
burrow in the earth, which led down beneath the roots of the tree into a dark underground cave. With his axe he cut a sapling and poked the end of it into the darkness. The pole struck something soft and yielding, and as he pushed upon it there came from the hole a complaining grunt. He poked again, and now he heard an ugly warning growl; he had found a black bear's den and the old bear was at home.

The black bear always has a snug cozy home for the cold months of the year. On the first approach of winter, he sets at work to put his house in order. Often his dwelling will be a cave in the rocks, and sometimes, when he comes to his home for the winter, he may find another bear already occupying his quarters. If he cannot find another cave, he makes himself a new one, usually selecting a spot beneath some big dead tree, where the digging will be easy. The soft earth flies while with his big powerful paws he burrows deep into the ground. The excavation finished, he lines the bottom a foot deep with hardwood leaves, and is ready to move in.

One cold night in November this bear, the mother of the cub in the lumber-camp, had crawled in to her retreat under the dead pine tree. Hidden away in her comfortable nest, she soon dropped off into her long winter's nap. The ground froze hard; the cold winds blew and piled the drifting 


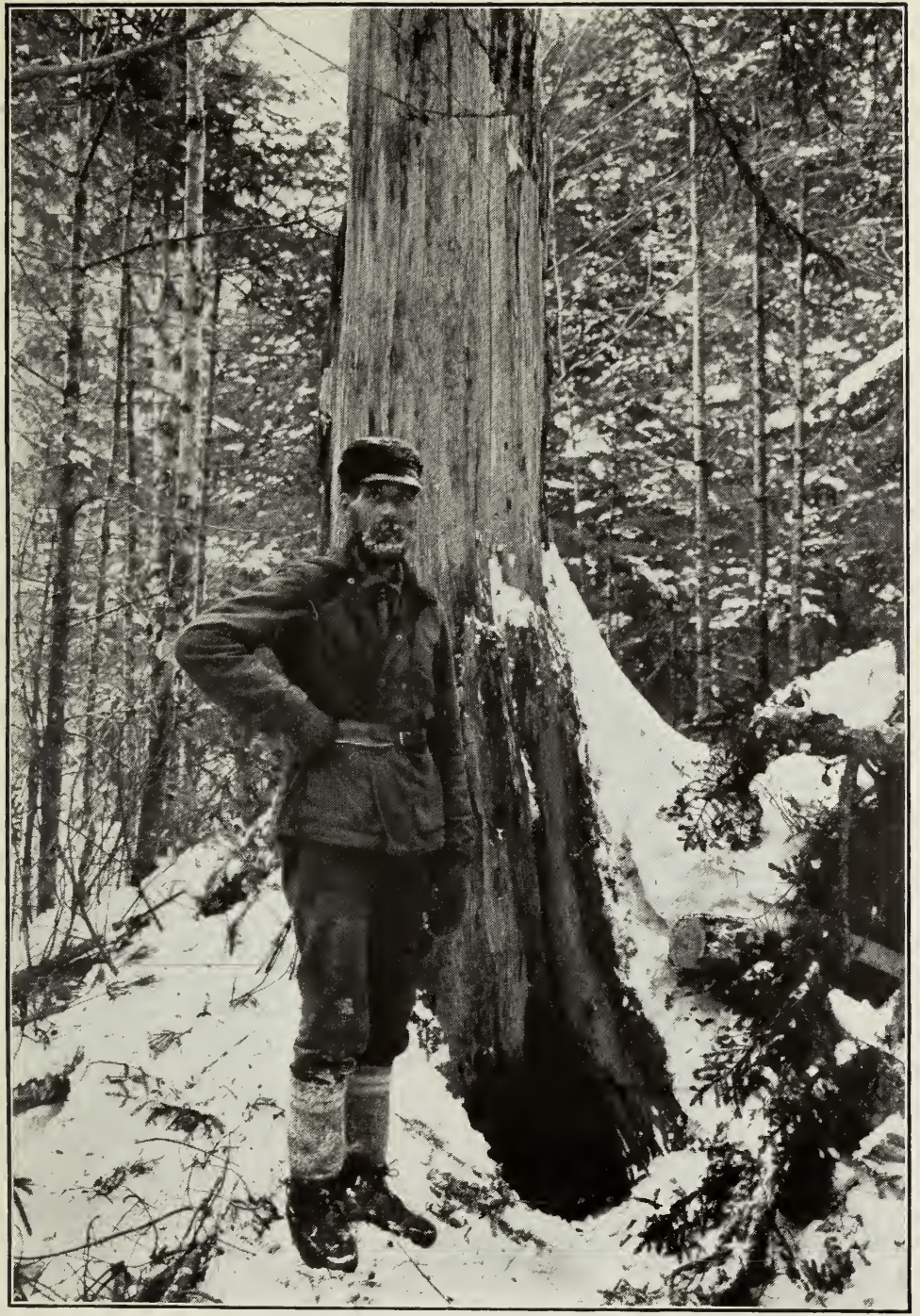

The den where the bear was born and the man who found him 



\section{AT GORDON'S CAMP}

snow across her doorway, but she slept on in her sheltered abode, with no thought of cold or the storms outside. The warmth of her furry body melted somewhat the surrounding snow and made a hole through to the outer air. This opening served as ventilator and chimney, and later on, when the cold of midwinter came, the damp snow froze hard and the mother bear was shut in for the season. It troubled her not at all, however, for wise Nature has made special provision for bears. During the time of plenty, in the late summer and early fall, when the wild berries and nuts are ripe, bears store up a harvest of fat beneath their sleek coats. Without this stock of nourishment to tide them over, these animals would starve in winter, for at this period they can find no suitable food. Through three or four months they sleep on, in blissful ignorance of conditions outside.

On his discovery of the bear, the cook ran back to the camp, secured a gun, and with one of the men returned to the dead pine. Poking the rifle down into the hole, he fired. The bear was killed, and with some difficulty the two men dragged her body out on the snow. They saw at once that their prize was a large one, a bear that would weigh more than two hundred pounds. Immediately they started to take off the skin and prepare the meat, and were proceeding with the work, when 
they were interrupted by a plaintive cry from the hole in the ground. They stopped and listened. Again they heard it, a whimpering, pitiful call of distress.

The cook lay flat on the snow, and reaching down into the den touched a small soft object. Wonderingly he drew it forth into the daylight. To his amazement he beheld a tiny little bear, no larger than a gray squirrel. Its eyes were not open, and it wriggled helplessly in his hand.

Of course the men, when they killed the bear, did not know about the cub down below, but it probably would have made no difference if they had. Bearskins were worth twenty-five dollars, and the state would pay a bounty of ten dollars; moreover, the meat was needed in the lumbercamp for food.

Few people realize how diminutive at birth black-bear cubs are. They weigh only from nine to twelve ounces, and are about the size of a little kitten. Their bodies are almost naked - only partly covered with short dark hair. Their eyes remain shut until they are about five weeks old. Not until their mother takes them out in the warm weather of spring, when they are three to four months old, do the cubs leave their birthplace. They are never seen in the woods until they have grown considerably and can run about with ease 
and, when occasion requires, climb a tree to a place of safety. Very few woodsmen or hunters are aware of these facts. The cubs that they see in May or June they will tell you are only three or four weeks old. Months, they should say.

When the meat had been prepared and the skin rolled into a bundle, the cub was slipped into the big pocket of the cook's overcoat and taken to the camp. The children laughed with glee, marveling at the wee small creature, and the lumbermen, coming in from felling the trees, gazed at it curiously and touched it tenderly with their rough hands. But what could be done with it? How could it be fed? Milk seemed to be the only proper thing to give it, since it was quite evident that the little animal had not yet been weaned; but where could they get any milk? They had no cow, nor did they have any canned milk, for that was in the days before condensed and evaporated milk had become part of the food-supply of every backwoods camp.

No one was able to suggest a plan for saving the life of the tiny orphan and, as the hours passed, death by starvation seemed to be its inevitable end. But the cub himself, having something to say on the matter, let his voice be heard in an unmistakable and universal language. $\mathrm{He}$ cried, and the meaning of his cry was: "Take me back to my 
mother; I am hungry and forsaken." The sound of his wailing was startlingly like that of an infant; anyone unaware would have said that a child was in distress. His whimpering little call for help, repeated again and again, touched the woman's tender heart; it suddenly occurred to her that there was one way out. She herself could save its life by letting it share the food that she was giving to her baby girl.

"You have killed its mother and I alone can save it," she said to her husband. "Poor lonely creature. I'll do my best to bring it up."

And so, with pity in her heart, she cherished the cub and took it to her breast. From the $23 \mathrm{~d}$ of January she had nursed it daily, and the milk of human kindness had sustained and saved its life.

Here was a story, sure enough. Was ever one like it told before?

It was very late when we retired. I took the inside of the bunk close to the logs of the wall. My big bedfellow was soon fast asleep, and save for the deep and regular breathing of the tired men and the hum of the tea-kettle on the stove, all was quiet.

For a long time I lay wide-awake. A lantern suspended from one of the rafters overhead shed a dim light on the simple wooded interior. Up above the stove, on a frame of sapling poles, long rows 


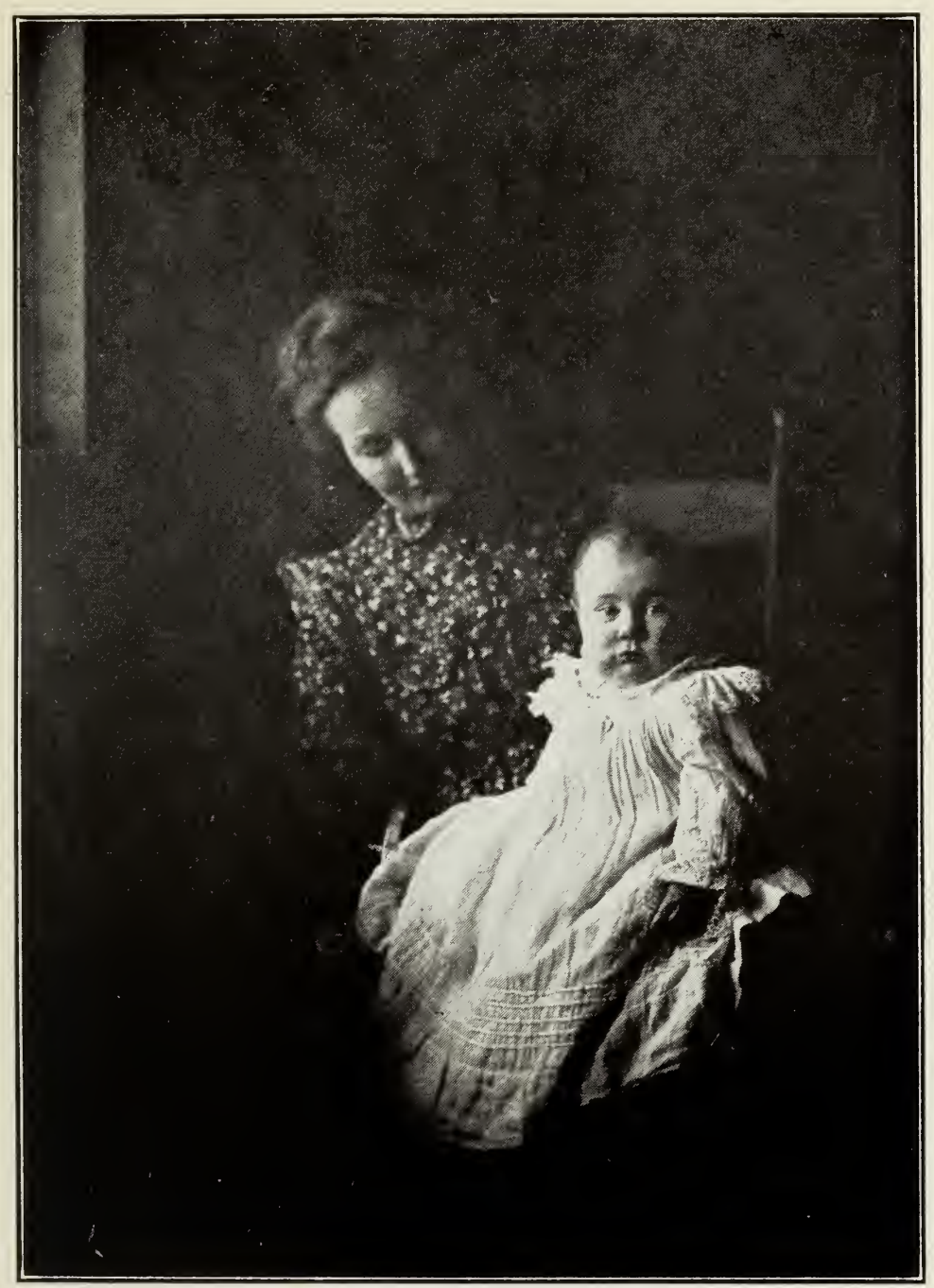

Life in the deep woods agreed with Ursula 



\section{AT GORDON'S CAMP}

of thick woolen socks were drying - to be ready and warm for the morning's work.

My thoughts went back to the stories I had read of life in the days of long ago, and I turned over and over in my mind the strange events of the day. It was hard to wait for the morning light, when I was to see the bear's den and take the pictures without which I feared that no one would believe my story. The spicy odor of the fir-bough bed beneath me finally induced a drowsy forgetfulness, however, and I dropped off to sleep. It was just coming light when my bunk-mate poked me in the ribs, and brought me back to the land of realities.

The men were sitting on the rough-hewn deacon seat, putting on their long woolen socks - pulling them up over their trousers, which were wrapped tightly round their ankles. They had scarcely finished, when the cook with a big spoon beat a vigorous tattoo on the bottom of a dishpan, to notify us that breakfast was served. Baked beans and pork, brown bread, saleratus biscuit, molasses ginger-cookies, apple-sauce, tea and coffee were the fare.

Outside, the air was bitter cold, with the thermometer standing at 20 degrees below zero; but mere cold was nothing to these hardy woodsmen, and after the dishes were washed, the cook sug- 
gested that I visit the bear's den. He would be glad to show me the way.

Strapping snowshoes on our feet, we set out through the woods for the dead pine tree that marked the spot where Bruno had been born. In the shelter of the forest the snow lay four feet deep on the level, and as we walked comfortably along on its surface, I wondered what these backwoodsmen would think if they saw us, as we sometimes do at home, leave the good walking on roads and sidewalks, and tramp with snowshoes across the fields, when there are only a few inches of snow on the ground. But here snowshoes are not used for sport. They are a necessity, and must be worn if one leaves the beaten track.

The den was not more than a third of a mile from the camp, and it seemed rather strange that the mother bear should have used it that winter, for Gordon built his cabins early in September and moved in during the last of that month. In December one of the men shot a large male bear only a short distance from the camp. In all probability this was Bruno's father. Male bears are often slow about turning in for the winter.

Close beside the branch road that had been swamped out in January stood the old pine. The opening of the den, as I saw it now, was much larger than when it was first discovered, on Jan- 


\section{AT GORDON'S CAMP}

uary 23 , for of course the snow had been cleared away in order to get the bear out. It looked like a comfortable place down inside - a round cave like a bowl, with a soft ten-inch bed of dry birch and maple leaves, mixed with a few pine-needles, covering the floor. Beneath this dry bedding were two or three inches of damp mouldy vegetation, showing that this winter home had been used for several seasons. With the exception of one small birch tree just behind the dead pine, there were no other hardwood trees in sight that could have furnished the material for the nest. Bruno's mother must have brought her bedding from quite a distance.

The cook stood close beside the open doorway, and I took my first picture. That it was intensely cold that morning can be seen by the white frost that covers his beard and moustache. The photograph was taken from the logging road. In order to clear the way for this road, a number of trees had been felled within a few feet of the den - apparently without in the least disturbing the hibernating bear. The newly cut end of a cedar stick can be seen just to the right, above the entrance.

As we walked back to camp, the cook told me that as yet his baby girl had not been named. His wife wanted to get a suitable name, something that would suggest to her daughter when she grew 
up that she had been foster-sister to a bear. "It would be fine, sir," said he, "if you could only think of some such name."

I told him that, after I reached home, I would do my best to find one that would be appropriate. My head was now too full of this strange adventure to give heed to anything else.

The next thing on my programme was to get a picture of Bruno; but this was not so easy. $\mathrm{He}$ was a helpless little creature, not yet able to stand up on his legs and walk, though with his fat little black-clothed body resting on the floor, he could wriggle and push himself about to some extent, like a baby just learning to creep. On February I9, the day before my arrival, he had opened his eyes for the first time. "I guess he heard you were coming, Mr. Underwood, and he wanted to see you," said one of the little girls. The naturalhistory books tell us that black bear-cubs get their eyes open when they are thirty or forty days old, so this would make Bruno's birthday about the I 5 th of January.

First, I weighed and measured him. From the end of his short stubby tail, which was only five eighths of an inch long, to the end of his nose, his length was twelve and a half inches. From the end of his nose to the back of his head, he measured three inches. Around his stocky little chest, the 


\section{AT GORDON'S CAMP}

tape showed eight and three quarters inches, and he weighed just two pounds - not a great weight for a month-old baby of a two-hundred-pound mother.

When I put my finger in his mouth he began to whine and to suck at it, and I could feel several small sharp teeth that were pricking up through the gums. He was hungry and wanted his food. It was nearly noon and baby sister was having her lunch.

"Why can't Bruno have some, too?" said one of the boys.

I had previously asked Mrs. Weldon if I could take a picture of the cub when he was feeding. I explained that no one would believe my story unless I could show proof of it. Very readily the good woman consented to my request. She was perfectly willing that I should show her picture. She merely asked that her name should be withheld. To this I gladly consented, and I further assured her that, for her better protection, all pictures of her, as well as those of the bear, would be copyrighted.

The faint light of the cabin was not sufficient for quick photography, and an instantaneous exposure would be necessary to secure good results. I saw that I should have to use a flashlight, and so I set my camera on a tripod, loaded the flashgun, and stood ready to fire. 
Comfortably settled in the mother's lap, both the bear and the baby were enjoying their midday refreshment. A proud and affectionate smile stole over the gentle woman's face as she glanced down at the little ones. I pulled the trigger, and there came a vivid flash and a dull heavy report that rattled the dishes on the shelves.

Pandemonium prevailed. The room was filled with smoke. Above the crying of the frightened children could be heard the high falsetto squeal of the terrified bear.

"Land sakes alive, Mr. Underwood!" exclaimed the startled parent. "Why did n't you tell us what was going to happen ?"

To add to the excitement and confusion the cook, who in the men's room had heard the jarring report, came rushing in. Blinded by the smoke and dismayed at the uproar, for a few minutes he was panic-stricken.

It took some time to quiet the family and assure them that no harm had been done. When the smoke had cleared away, I explained to them that, if I had told them what was going to happen, they would have been frightened before the event occurred, and the mother's expression would have been strange and unnatural.

Now that everything was all right, and no one had been hurt, the children were for having an- 


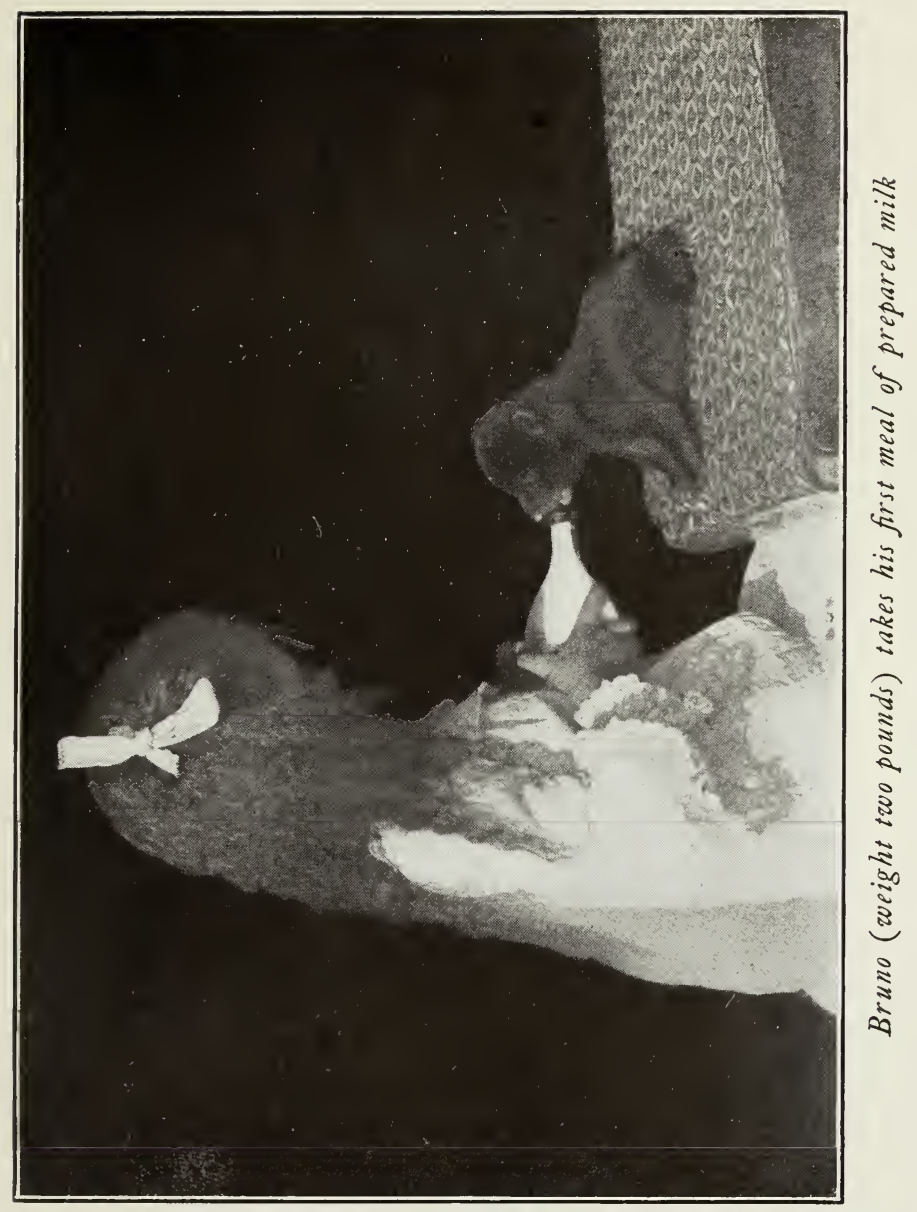





\section{AT GORDON'S CAMP}

other exhibition, and they asked me to fire another shot. So I took a picture of the baby sister in her mother's lap. She was now nearly nine months old, and in order that there should be plenty of food for her foster-brother, she was being weaned, and occasionally they fed her on that good old New England stand-by, baked beans and pork. It may be seen by referring to her picture that the diet agreed with her.

As I had hoped to buy the bear and take him home with me, I had brought a nursing-bottle and some cans of condensed milk - then a rare commodity in the woods - so that he could be well fed on his journey to Boston. Diluting the milk with warm water, I now filled the bottle, and the oldest child gave Bruno his first commercial food. Stretched out on the table-top, with his fat little body sagging down on the oilcloth cover, he took his new fare with apparent relish.

This pleased me very much, for now I should have no trouble about feeding him on the, way home. It soon proved, however, that I had been a little "previous" in my calculations, for when I asked Mrs. Weldon how much money she wanted for the bear, I received an instant rebuff.

"Sell my cub? I guess not!" she exclaimed with great indignation; and then added: "Why, Mr. Underwood, you have n't got money enough 
to buy him. I would n't any more sell Bruno than I would sell my baby, and you must know that I would n't sell my baby."

Just to try her, I took twenty-five dollars from my pocket and asked her to accept it, remarking that I had understood that it was for sale, and in fact I had been told before I left Boston that it had been sold.

"No, sir, it is not for sale," she emphatically replied: "not for twenty times twenty-five dollars. You could n't carry enough money in your pockets to buy this bear, Mr. Underwood."

This seemed quite final, but I inquired further about the letter that $I$ had received telling me of the sale. And this is the story that I was told, first by Mrs. Weldon, and afterward by some of the men.

The first time Gordon, the boss of the camp, went out to the settlement and told about the little bear, some commercial traveling men, hearing the story, offered to buy the cub. They thought that they might make some money by exhibiting a bear which had been brought up in such an unusual way. To bind the bargain and make sure of their prize, they gave the boss a check. A few days later, Gordon went back into the woods to get the cub, but the woman refused to give it up. It was her bear, she had saved its life, and no one was going to take it from her. 


\section{AT GORDON'S CAMP}

But Gordon would not listen to her pleading. He was the boss of that camp; he had sold that bear and had received the money, and he was going to deliver the goods.

The cook, a mild-mannered man, advised his wife not to make any trouble but to give the cub up. Very unwillingly she consented, and Biruno was taken into the men's cabin, where he was to spend the night before leaving for the village next day. Toward evening, the cub became hungry and began to cry for his supper. As his suffering grew more intense, his cries became the louder, until Mrs. Weldon in the adjoining cabin heard his pitiful voice, and in sympathy she too began to cry.

At sunset the men, tired from their long day's work, came back to the camp. The bear was howling and the woman crying. The outlook for a quiet night seemed not very good. Injustice was being done. An indignation meeting was held, and the boss was requested to relieve the situation. The crew demanded that Bruno be returned. "She saved his life, and he belongs to her," they said. "You give him back to-night, or to-morrow we quit work. You can stay and cut spruce, but you'll cut it alone. Give him back or we are done."

It was a righteous strike; the boss gave in, and once more the bear was saved. 


\section{WILD BROTHER}

Soon after lunch my teamster arrived, and we started back for the settlements with one of the woodsmen who was going out. We were talking about the bear, when I mentioned that I had a duty to perform - that I must find a suitable name for the baby.

"I wish yer would git a name fer that kid, Mr. Underwood," said the lumberman. "Us fellers has scratched our hair thin on the tops of our heads, and we've wore out all the almanacs in camp lookin' fer a good name fer that girl."

After reaching home my first concern was to develop my photographs - and they came out very well. I next gave my mind to the selection of a name for the foster-sister. In a family council we went thoroughly into the question. After due deliberation, it was unanimously voted that Ursula was most appropriate. I wrote a letter to Mrs. Weldon, and told her that Ursula was a Latin word meaning little she-bear, and I sent her a silver spoon that had come from Berne, Switzerland. On the top of its handle was a little silver bear, and on the bowl I had had engraved, "Ursula, February 20, 1903"; and by that name the baby was christened, though they threw in for good measure the ponderous name of Underwood. To make up for this defect, however, they called her Lala for short. 


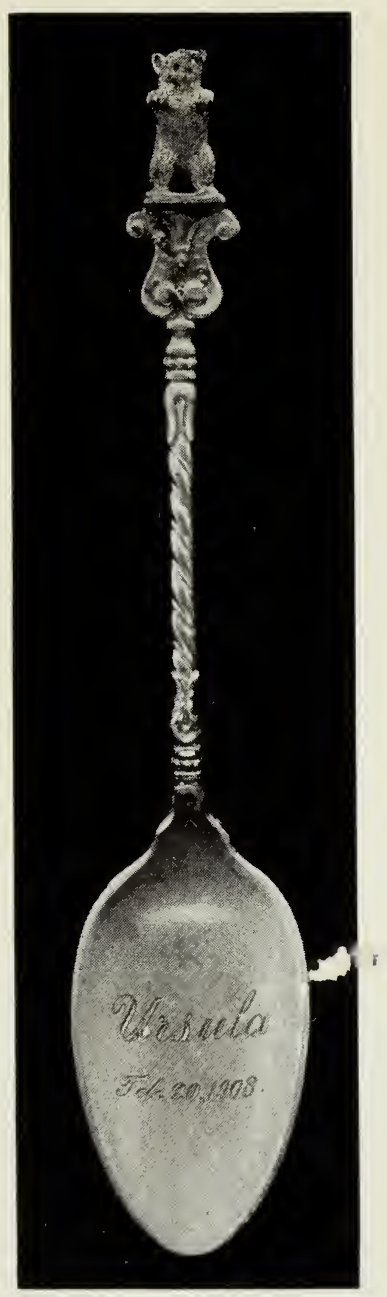

By this name the foster-sister of the bear was christened 

After my return from Maine the attitude of my friends toward the story changed somewhat. When they had heard of the incident before I set out on my quest, they had ridiculed the idea. They would not believe that any woman would take care of a bear in that way. The thought of such a thing was repellent to them.

"Why!" they exclaimed, "you could n't take a photograph of such an occurrence; and even if you should take one, you never could show it to anyone, for no one would care to see it."

To this argument I had replied that I would not cross the bridge until I came to it. If the thing was being done, it was unusual enough to warrant an investigation. I wanted to get the truth, if for no other reason than my own satisfaction.

Now, when my critics understood the motive behind Mrs. Weldon's deed of compassion, and when they saw her pictures and looked upon her kindly face, they realized that their position was wholly wrong. Here was a humble woman, whose sympathetic heart was torn by a cry of distress from the wilderness, a call that her gentle nature could not resist. Alone with her loving family, with no thought or care for what the world outside might think, she did the natural thing and obeyed her impulse to save a life. All honor to her for her compassion! 
The effect that the story had upon different people, however, was rather curious. I soon learned that it was better not to tell it, especially if ladies were present, without the pictures to prove my facts and to show the real character of Mrs. Weldon. I had a striking example of this feeling several years after my first introduction to the bear, when the story had become rather well known in my vicinity.

One afternoon in summer, a number of men and women were sitting about on the verandah of a hotel. The men were discussing various sports, particularly fishing and hunting. The subject of bears came up, and in the course of conversation someone asked if anyone had heard about the bear that was brought up as a child. One lady replied, "Yes, I have heard about it, and I think it is the most disgusting story that I ever listened to."

I immediately sat up and gave attention. She seemed quite angry and impatient. "I can't imagine any woman doing such a horrible thing," she went on.

After her resentment had been fully expressed, and she had quieted down a bit, a general discussion ensued. At the first lull in the conversation, I mildly asked the lady where she had heard the story, and received the reply that her husband had told her about it. 


\section{AT GORDON'S CAMP}

"Did he tell you why the woman had done such a thing ?" I inquired.

"Oh, for the sake of notoriety I suppose," she replied.

Here was my chance and I improved it.

"Now," I said, "I should like to tell you the truth about that story if you would care to hear it."

She was rather indifferent, but the other people were keen for it, and I gave them the real facts. I happened to have some of my photographs with me, and offered to get them if anyone wished to see them. The lady took no particular interest in them at first; but when they were passed around, and the other people began to express their surprise and pleasure, she condescended to take a look.

Rather to my surprise, some time afterwards, this same person asked me if I would mind showing the pictures to her little girl! She then admitted that she had been wrong in her judgment about the story.

Weeks went by, and I heard nothing more from my forest friends. Evidently Bruno was behaving himself, for Mrs. Weldon had promised to let me know if he got too big and strong, and, either in play or intentionally, hurt his foster-sister, Ursula.

On the approach of spring, as the days grew longer and lost their wintry chill, I began to experience, as usual at that season of the year, a cer- 
tain restlessness that betokened the approach of an attack of spring fever. Each night I dreamed of woods and fields, of sunlit lakes and shady forest streams. By the first of May the malady was at its height.

There is only one really effective thing to be done for spring fever. With me the remedy is simple if quickly applied. It is to say good-bye to the city, close my desk, shut my door, and buy a ticket for the woods.

On the 3 rd of May this remedy was applied, and Comrade and I were off for a spring outing, to visit my camp in Maine. I was getting together material for lectures on the lumber industry that year, and now it occurred to me that a side-trip to visit the lumber-camp where Bruno was living would serve two purposes, for I was anxious to see again the Weldons and the cub. 


\section{CHAPTER III}

\section{MAY-TIME IN THE FOREST}

IN I903 spring came much earlier than usual. The ice went out of the lakes in our region of Maine about the middle of April, more than two weeks ahead of the average date, and when we went into Gordon's camp, the season had completely changed the appearance of the country. The logs that in February were being hauled on to the ice were now floating in a big boom at the foot of the lake. The gate had been hoisted in the dam, and the stream down below, swollen to a freshet pitch, was full of big sticks, tossing and swerving as they shot like arrows down through the white-water rapids. A crew of river-drivers, with long steel-shod pickpoles, lined the banks to guide and push off the logs that often threatened to run aground on the sharp bends in the river. A few weeks before, when winter had held the northland in its grip, I had listened to the shrilling of sled-runners on hard snow and to the snapping of trees in the frost; now the songs of the earliest birds and the calling of the hylas and wood-frogs mingled with the sound of running water, and our eyes were greeted with bursting buds and with green shoots breaking the forest floor, in haste to answer the call of the May sunshine. 
Mrs. Weldon gave us a warm welcome, and with considerable pride brought Bruno forward for our inspection. He had grown considerably since I had seen him in February. He was now a typical fat, chubby Teddy Bear, seven pounds in weight. On March 20, when he was two months old, he had weighed three and a quarter pounds, and on that day had walked for the first time. His round little body was now covered with a soft thick coat of brown curly wool. The short black silky hair with which he had been clothed when I first saw him in February had disappeared.

In Kipling's "Jungle Book," Baloo, the wise old bear, in telling of the laws for the guidance of the wood-folk, says :-

"Oppress not the cubs of the stranger, but hail them as Sister and Brother,

For though they are little and fubsy, it may be the Bear is their mother."

"Fubsy" was just the right word to describe Bruno's appearance at this age. Fubsy and fat he was, and jolly was his nature. He had got on splendidly with his foster-brothers and sisters and why should he not? A better-behaved lot of children I had never met. They were kind and considerate of each other, and their attitude toward their parents was exceptionally fine. There 
was no disobedience in that little family, and never a harsh word did I hear spoken.

Mrs. Weldon had taken some schoolbooks into the woods with her, and now she was teaching the little ones to read and write. Not only from books did she instruct them; she taught them also, by example, good manners, politeness, and kindness. No favors were ever shown to her own children in which the adopted ones did not share. Many times she had related to them the Bible story of the Prophet Elisha, who had been mocked and insulted by the children of Bethel. Very seriously she told them how Elisha, when these children had shouted at him, "Go up, thou Baldhead," had called from the woods two great mother bears. With a solemn face she emphasized the moral of the story, as she told how the great beasts rushed out from the forest, and, as a punishment for the children's rudeness, tore some forty of them into bits.

Whenever Bruno got a chance, he crawled into the cradle and went to sleep beside little Ursula. Snuggling close to her, he poked his soft woolly muzzle under her chin, and, crooning a lullaby in bear language, joined the baby in dreamland.

Mrs. Weldon had begun to wean the cub in March. At first he did not like the condensed milk that I had brought in; and for a time he was made 
so sick that it was necessary to put him again on his original diet. On April 4 she had nursed him for the last time. For more than a month now, stale bread and condensed milk diluted with water had been his daily fare. Perhaps the condensed milk helped to develop his sweet tooth, for he became very fond of sugar. He would often climb up on the table before the dishes had been cleared away and look about for a piece of cake, and put his nose down into all the tea-cups to see if by chance any sugar had been left in the bottom. One day he found a jam-bucket that had been left on the kitchen table. When they discovered him, most of the jam had disappeared. One glance at the cub's round distended body told where the jam was secreted.

"How much jam would he eat?" I asked Mrs. Weldon.

"We never had enough to find out!" she answered.

"Do these sweet things agree with him ?"

"No. Sometimes he gets an awful stomachache."

"What do you do then?" I inquired.

"Oh, we give him Castoria, same as we do the baby, and he always comes round all right again."

Of all the foods that were sweet, honey was the most to Bruno's liking - a taste which he had, 


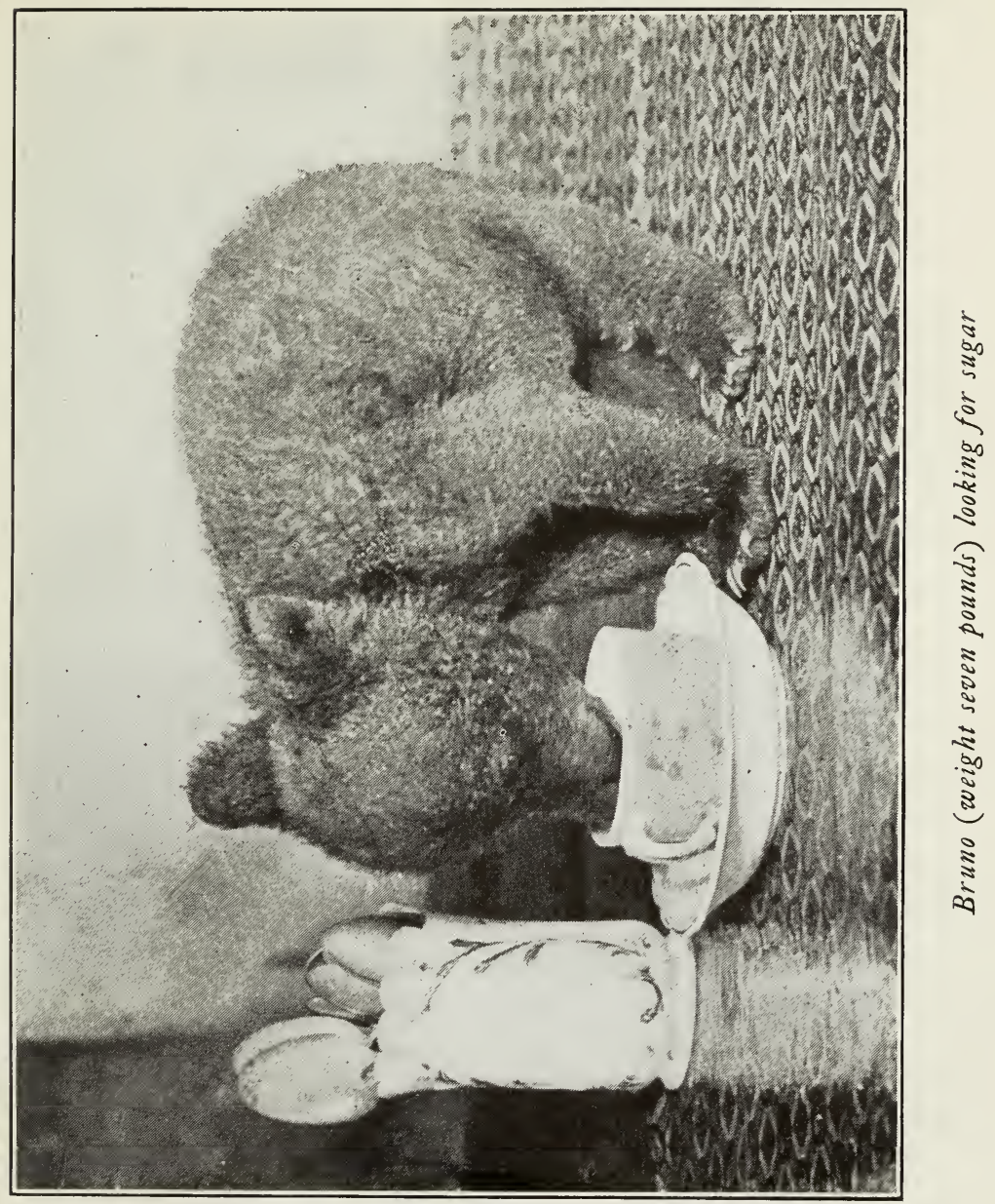



doubtless, inherited, for all black bears are good wild-bee hunters. They highly prize wild honey, and when they find a bee tree quickly tear it apart. With paws and face daubed with the gluey golden liquid, and besieged by thousands of angry buzzing bees, Bruin enjoys his stolen fruit. Grunting with satisfaction, he champs his jaws, stopping now and then to sneeze, and with his sticky paws to wipe away the swarm of infuriated insects that are crawling over his face and eyes. His fur is so thick and heavy that his enemies seldom find a vulnerable point of attack.

But our Bruno had no enemy to fight when he ate his honey, of which there was a good stock in Gordon's camp. Oh, no, the pampered pethoney was fed to him in an iron spoon. His beady black eyes rolled around in ecstasy, while his round woolly sides twitched with pleasure and excitement, as, smacking his lips, he wound his long pink tongue round the honey-covered spoon.

We had brought in with us some fruit and candy for the children. While they were receiving these little gifts with shouts of delight, we heard a curious scratching noise under the table - and there was Bruno in the middle of our suit-case, overhauling the contents with his mischievous paws. Collars and socks, neckties and hair-brushes, were scattered hither and yon, as in frantic haste he 
searched for his stick of candy. He did not intend to be left out of the family reckoning!

Bruno was allowed to go wherever he pleased, but he seldom went out of sight of his fostermother or the children. Always he wanted to be near Mrs. Weldon. Like a dog, he would follow her about wherever she went; but he did not care for the big woods, and seemed nervous and timid when alone in the forest. One day Mrs. Weldon went out to gather some spring flowers. On tiptoe, silently she left the cabin, for the cub was sound asleep in his box by the stove; she was going quite a distance and she did not wish him to follow her. Taking her way along one of the logging roads that zigzagged back and forth up the slope of a hardwood ridge, she stopped now and then to gather a bunch of painted trillium, or to look underneath the fallen leaves for the fragrant pink blossoms of the trailing arbutus, which in deeply shaded spots was still in bloom.

Near the top of the ridge she paused to rest and, sitting on a mossy log, she listened with great delight to the chanting song of a hermit thrush that came up from the rill down below. On a treetop high above her head a white-throated sparrow now softly called in silvery tones for his lifelong friend, Sam Peabody, Peabody, Peabody. Silently she listened to the joyous music. 


\section{MAY-TIME IN THE FOREST}

But now there came a discord in the forest symphony. The whining tone of some small animal in trouble broke in upon the harmony of the woodland orchestra. From down below came a rustle of dried leaves and the sound of pattering feet drawing nearer.

Mrs. Weldon rose and, looking down the hill, saw her Bruno trudging up the trail. With his nose close to the ground, panting and crying in distress, he was wandering back and forth, following her footsteps. When at last he came upon her, he wriggled and wobbled in a frenzy of joy. Back and forth for more than half a mile he had scented and followed her track.

Several times later the cub followed her into the woods in the same way. On one occasion, she went a long distance from the camp, to gather fiddlehead ferns, the tender fronds of which, just as they are uncurling, make delicious greens for the dinnertable. When she returned, after several hours, Bruno was missing and could not be found. The lumbermen stopped their work to hunt for him. They scoured the woods in every direction; and at last they heard his whimpering, and presently saw him coming.

Standing aside quietly, they watched him. He was visiting every spot where Mrs. Weldon had picked the ferns. They called to him. He paid no 
attention to them, but kept on searching for his friend. Keeping in the background, they trailed on behind, until, following Mrs. Weldon's footprints, Bruno took them back to the camp.

Mrs. Underwood and I spent two weeks near the stream where the river-drivers were working. Each day with my camera I walked along the banks, taking pictures and watching the men at their exciting work. Most of Gordon's crew were on the drive, and they took great interest in what I was doing. They seemed to consider it as a great honor that Comrade had come back into the woods to watch them.

The life of a river-driver is hard: his days are long, and the work is rough and dangerous. The water is icy cold. The snow still lingers in the woods, and the drive begins on the day when the ice leaves the lakes. On our stream the men were most accommodating: they did everything they could for me so that my pictures should be successful. Where the stream was narrow, they felled trees across to make bridges, so that Mrs. Underwood and I could pass from one bank to another. All kinds of stunts were done for our benefit. They had burling contests, in which two men stood on a single log, each trying to roll the other off. The man who fell had to swim. Wet clothes were of no moment to those husky chaps. That 


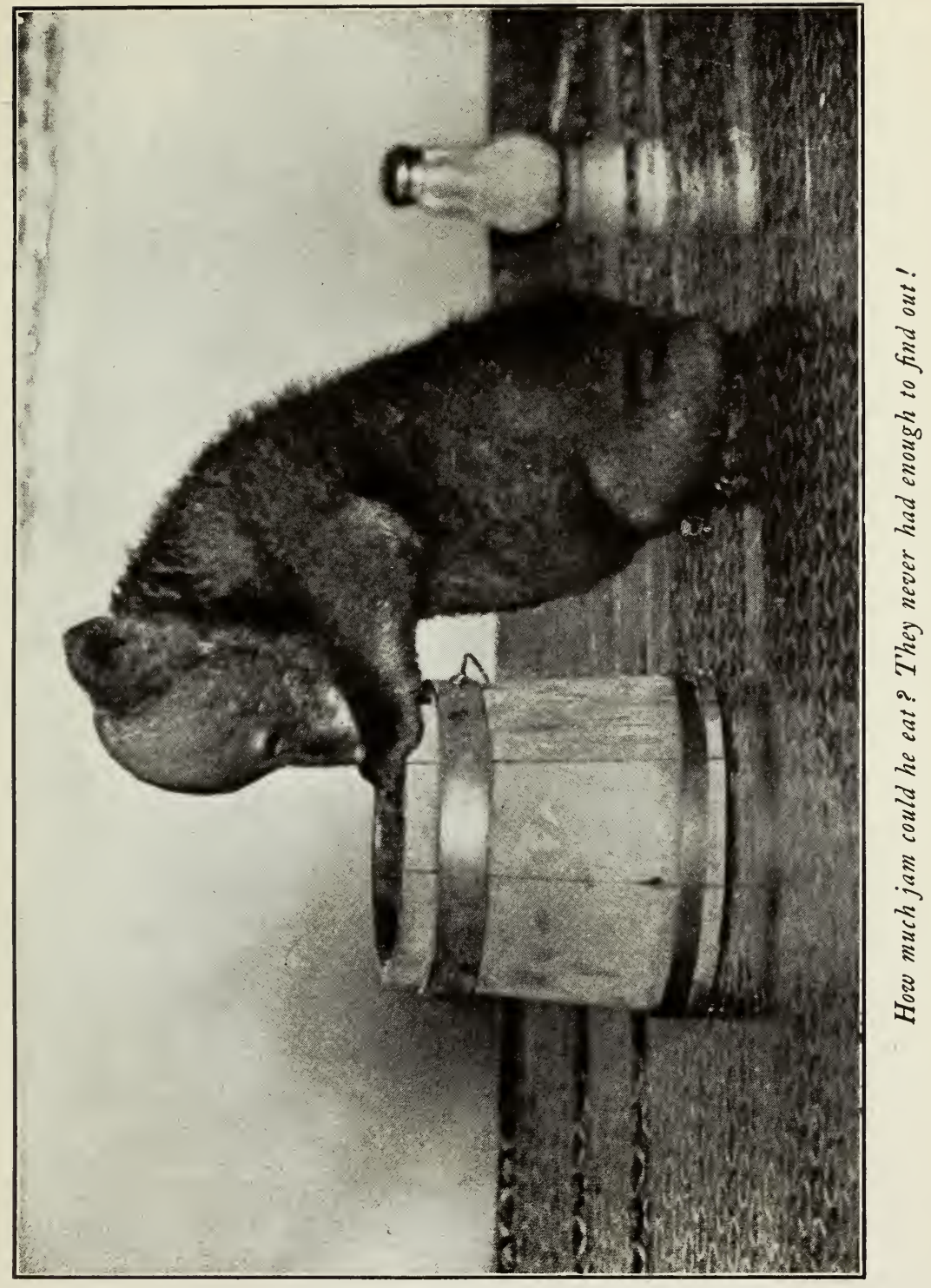



was an everyday condition. Any man who changed his clothes because they were wet would be laughed out of camp. Poised on a single log and balancing themselves with pick-poles or cantdogs, they ran down through the whirling current, stamping their feet up and down as if dancing a jig, as the stick rolled beneath them.

The spring of 1903 was hard for the lumber industry. No rains came to keep the lakes at high level, and day by day the water dropped. Half-way between the upper and the lower lakes the stream ran for a short distance over a wide rocky ledge. In the space of fifty yards it dropped some ten feet, and over this pitch the water was spread very thin. At this point the logs were continually hanging. Whenever a stick began to slow up, or twist about so that its end might be forced out on the bank, two or three men rushed into the rapid water and made the white spray fly, while with their cant-dogs they pried the log out into the centre of the stream. In spite of all they could do, the timber sometimes jammed on this ledge, and then from bank to bank the logs lay in a tangled mass like huge jackstraws.

Here was danger; but without a moment's hesitation the nimble-footed rivermen ran out upon the interwoven timber, and with poles and peavies tugged and heaved until the strain was lessened, 
and under the weight of water that for the time being was backed up behind the jam, the whole mass trembled, then slowly started down-river. Now the men turned toward the bank, for the jam was gaining speed. The logs seemed to be alive; they twisted and shook themselves, and as they struck the rocks, the air resounded with the resonant voice of the booming timber. Like squirrels, the men jumped from one stick to another and gained the shore.

Some of these fellows are so adept that they are called "bubble walkers"; it is said of them that, if no logs offer a footing, they can come ashore on the bubbles. But in spite of their supple bodies and their nimble feet, the drive each spring claims its victims from among them. One afternoon there came into our camp a silent group of men on their way out to the village. They bore in their midst a litter, and on it lay, under a sheet of canvas, a river-driver, a young Indian. That morning he had been working with several other drivers at a jam on a distant stream. When it broke, everyone leaped for the bank. Suddenly the end of a stick thrust itself up from the water in front of the Indian. He tripped over it and fell into the grinding mass. Two logs came together, and he was between them. Others piled on top. It was all over in a moment. And now the men were 
taking his body to his home down-river.

Sometimes, when the wind blew strongly from the south and held the logs in a compact mass, blocking the mouth of the stream in the lower lake, all sluicing would have to be suspended. Then the men would busy themselves clearing convenient vantage-points from which I could take my photographs. To Comrade they brought in bunches of delicate Mayflowers, and the sweet odor of the arbutus made fragrant the air of our camp.

On Sundays, or when the work was slack, some of the crew often went over to Gordon's camp, four miles through the woods, to see the bear and to watch his antics. Mrs. Weldon never allowed them to plague Bruno. In fact, she had made a hard-and-fast rule that no one except the members of the family should lay their hands on the cub; and this law the men respected.

Bruno had one little act that always pleased his audience. The children called it "rolypoly." Close beside the camp ran a rippling forest brook. Ten feet above the water, at the top of the sloping mossy bank, stood the log cabins. Here in the afternoon sun, under the shelter of the buildings, the cub often came out to exercise and play. This particular attraction began with a short but rapid whirling dance. Shaking his head from side to side and sticking his upper lip out beyond the end of 
his nose, in an absurdly grotesque manner, he began, as if on a pivot, to turn round and round like a kitten when chasing its tail.

After this exercise had continued for a minute or two, he would stop suddenly and, wagging his head up and down, would rush straight ahead for a few yards. Then again he would pause, wheel about, and run like mad in the opposite direction. These capers he repeated several times; then suddenly he would pick up a small stick or a chip of wood, and, holding it in his mouth, would curl himself into a round brown ball and roll head over heels down the mossy incline, sometimes not stopping till he bounced with a splash into the cold water of the brook. This climax to his act always brought great applause from the lumbermen, who swore that Bruno was surely going to be a riverdriver of great merit.

Before our outing was over, we called once more at Bruno's home, and again I tried to buy the little bear; but as before Mrs. Weldon would not consider parting with him.

"If he becomes cross or rough when he grows larger, and Ursula should be in danger, I will let you know," she said; " and then, if you want to buy him, I will give him up." 


\section{CHAPTER IV}

\section{THE BEAR MAKES A JOURNEY}

EARLY in June there came a letter from the woods. Bruno was growing fast, and, though he was not cross, he was big and strong, and in his play had developed a roughness that threatened harm to Ursula. A day or two before, while he was playing with his foster-sister, he had jumped upon her as she sat on the floor, and knocked her over and bumped her head. They expected to leave camp in a few days; and when I came down again, Mrs. Weldon would sell him to me, provided I would pay her enough to buy a cow.

If ever a person deserved a cow, Mrs. Weldon did, and I wrote to tell her that she should have one.

A week later Mrs. Underwood and I arrived at the village, and were much disappointed to learn that the Weldons had not yet come out of the woods. The townspeople expressed considerable anxiety about them. Forest-fires were raging all through New England, and for weeks the sun had hung a red ball of fire in a smoky sky. No spring rains had come to refresh the thirsty earth; for fifty days not a drop of water had fallen. Just before our arrival, a little settlement twenty-five miles to 
the north of Gordon's camp had been burned out. We were advised to keep away from this section until the drought was broken; but I could not think of going back without the bear - and so we decided to make one more trip in to the lumbercamp.

On this calm June morning not a leaf was stirring in the tree-tops. If there had been any breeze, it would have been unwise to start. The roads were now dried out, and we could take the regular highway to a point within four miles of the camp. To be sure, this was considerably longer than the winter trail, but we could cover the distance in much less time and with far greater comfort.

With a fine pair of horses hitched to a rough lumber wagon, we rattled over the ground at a good rate of speed. A little before noon we left the regular road and drew in to the woods, where the smoke was thick and its pungent odor more oppressive. No city teamster would have thought it possible to move a wagon over that rough logging trail, but our backwoods horses knew their business, and they jerked along over rocks and down into gullies at a brisk walk. Only by great care were we able to stay in the wagon. Finally I gave up; it was much easier and more comfortable to walk. Comrade, however, stuck to the wagon. With a broad strap we tied her in, and for the balance of the 


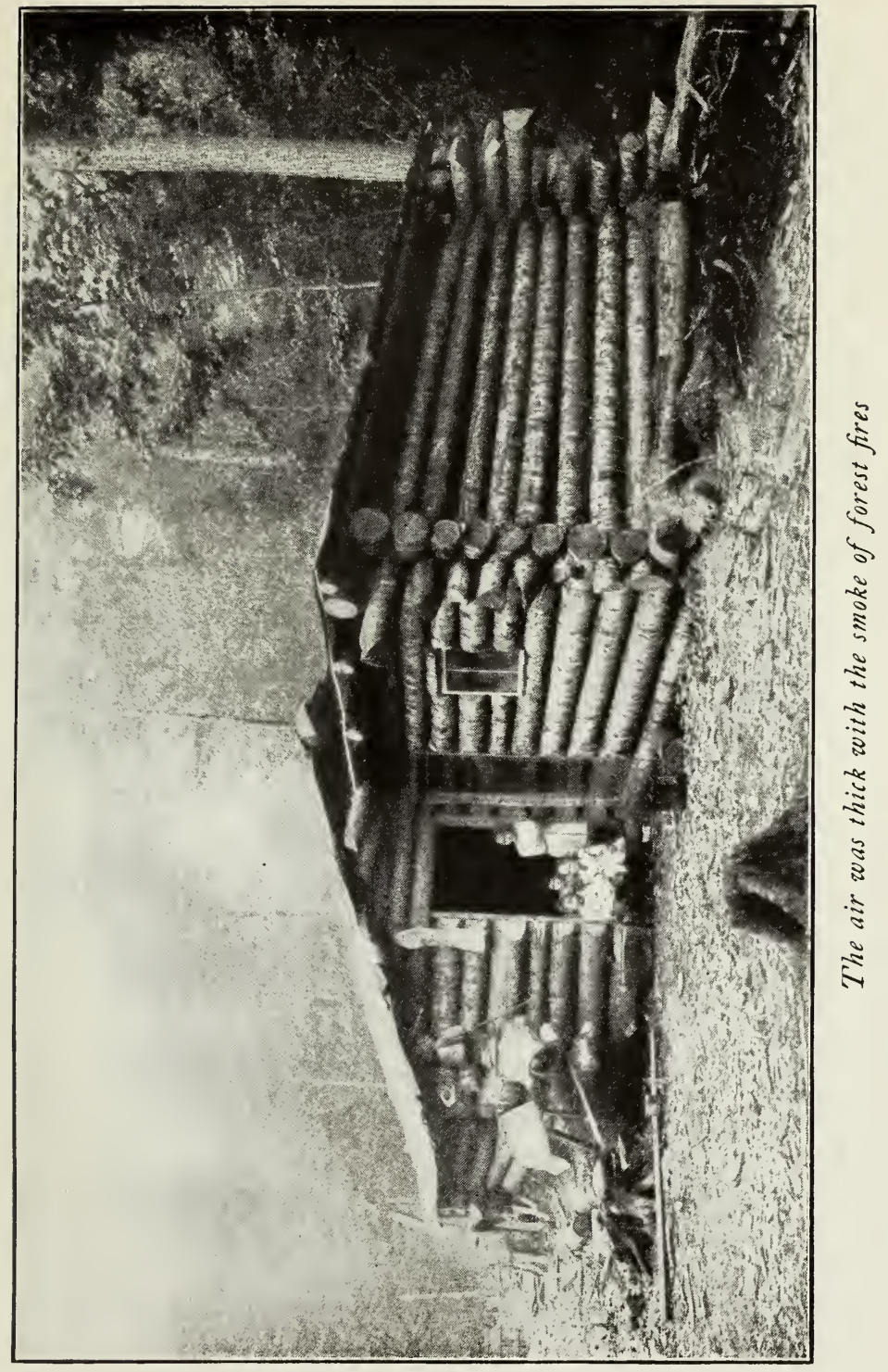



journey she got more exercise than I did. Occasionally we paused to rest the horses. All along the way we now began to see on the ground bits of charred and blackened leaves, which, on previous days, had been carried on the dry air from the burning forest to the north of us.

About one o'clock, while I was walking ahead, I came into a clearing where a log cabin stood. In the smoky atmosphere it did not look like Gordon's camp. I rubbed my eyes and looked again. Yes, this was the place all right; we had approached it from a different direction, and there was Bruno climbing a tree near the cabin. The children, who were sitting in the doorway, sprang up and gave us a happy welcome. The family seemed not at all alarmed about the forest fires, though the smoke was now so thick that the tree-tops only a short distance away could hardly be seen through the murky air.

In case the conflagration should sweep their way, the Weldons were prepared. A short distance behind the cabin, in the side of the bank, they had dug a pit ten feet deep and ten feet square. Over its top were sapling trees and spruce boughs, and over these dirt and sods. Into the brook, just below the spot where they had dug the underground room, they had thrown a quantity of earth, which had formed a dam and backed the water 
close to the door of the cave. If the fire should come, it would take them only a few minutes, they said, to stock and provision their place of refuge. To be sure, the log cabin would go, but they would be safe; in a few hours the fire would spend itself and pass on.

It seemed foolhardy for anyone to take such chances, but there was money to be made by the cutting and getting out of cedar trees. A good stand of this timber grew close by, and cedar is valuable for railroad ties and telegraph poles. Only three men were now at the camp. The rest of the crew had left when the river-driving was over.

Bruno was an active member of the Weldon family. He could climb like a squirrel, and if the tree were hollow, he liked to crawl inside and from a hole watch his comrades at their games, as if he were playing hide and seek with them. Another one of his favorite pastimes was trying to help when the cook was splitting kindling wood, though $\mathrm{Mr}$. Weldon considered him more of a hindrance than a help, for Bruno would rush in from behind and try to pull away a piece of wood that was being split, and sometimes was in great danger of losing his paws, for the axe was sharp. He loved to pick up the small pieces as they fell from the choppingblock. Holding them in his mouth, he would prance about like a puppy, chasing up and down 


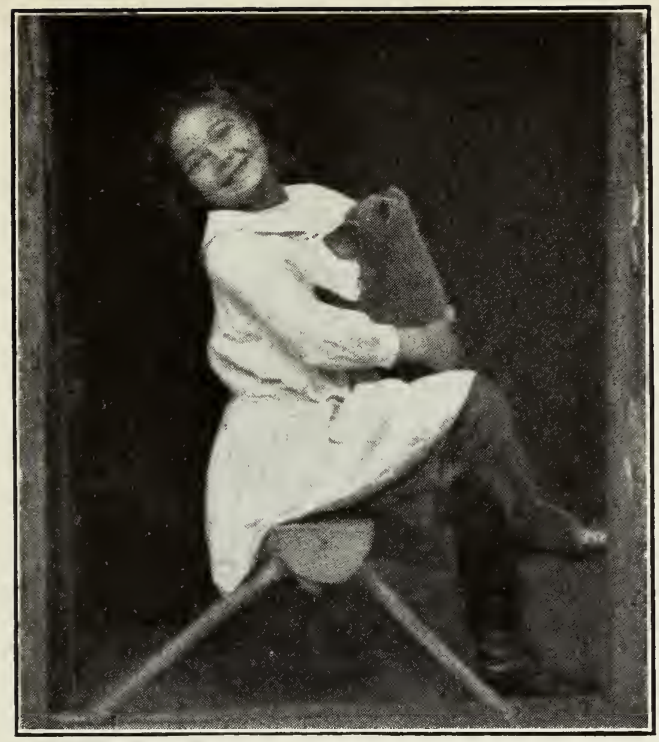

Bruno and his oldest sister on the day he left home

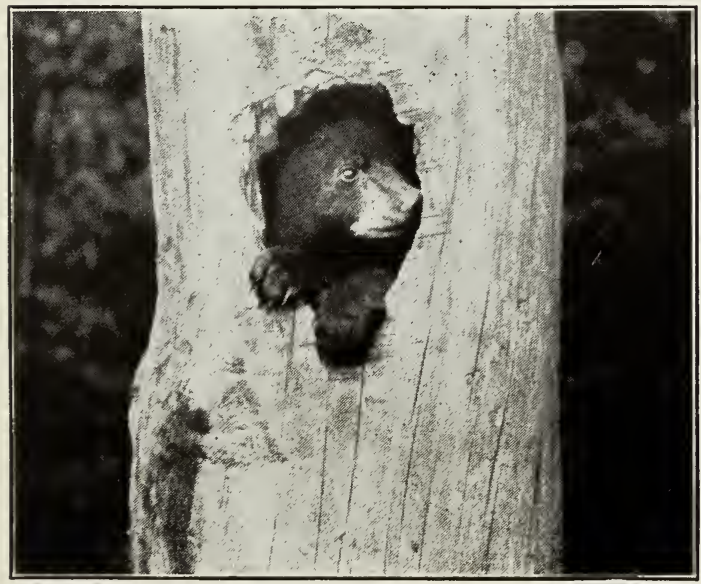

The cub liked to crawl inside and watch the children as if he were playing hide and seek 

over the woodpile and scattering the kindling all about.

As he had increased in size and strength, Mrs. Weldon felt a little anxious about letting him sleep with Ursula, unless she were close at hand to watch them. In order to keep him away from the cradle, they had put a lattice-gate in the doorway between the kitchen and the bedroom. This did not keep Bruno out, however, for he soon learned to climb over it. Pulling himself up hand over hand like a monkey, he would gain the top, then, huddled into a furry bundle, he would drop awkwardly, often bottom-side-up, to the floor. Whining as he uncurled himself, he would waddle across the room, his long little toe-nails clicking as he ran, and jumping into the cradle, would soon be sound asleep, nestled close to the baby.

From what Mrs. Weldon had written me, I had expected that Bruno would be much larger than I now found him. He was nearly five months old, yet he weighed only eleven and a half pounds. From her letters I had inferred that he would be fully twice his present size. On the lumber wagon I had brought a large dry-goods box about the size of a piano case. I had also bought a collar for the cub - one that would be about right for an ordinary setter dog. Both these articles were misfits. The collar was so large that Bruno could 
walk right through it without any trouble, while a soap-box would have furnished him with much more comfortable quarters than my packing-case.

Soon after our arrival a brisk wind came out of the north, and as a protracted sojourn in the underground fire retreat offered no attractions to us, we made haste to move out. Bruno was playing in the lap of his oldest sister. They were having a great frolic; with his long claws the cub was tickling her, while he stood on his hind-legs and tried to kiss her on the chin. The little girl's happy laugh quickly changed to a bitter cry of disappointment when Bruno was taken from her, and she learned that she would lose her playmate and never see him again. It was a sad occasion for all that happy family, and Mrs. Weldon was even more distressed than the others. She told me that, under similar circumstances, she would gladly adopt another bear.

All the children were sobbing. The bear was the only happy member of the group. He, lucky creature, did not know that he was to be taken away, though a few minutes before the time of parting he had unconsciously kissed Sister Ursula good-bye. Ursula had been sitting on the oilcloth table-top, watching her brothers and sisters, who were crying at the thought of the coming separation - and herself feeling a little sad in sympathy. 


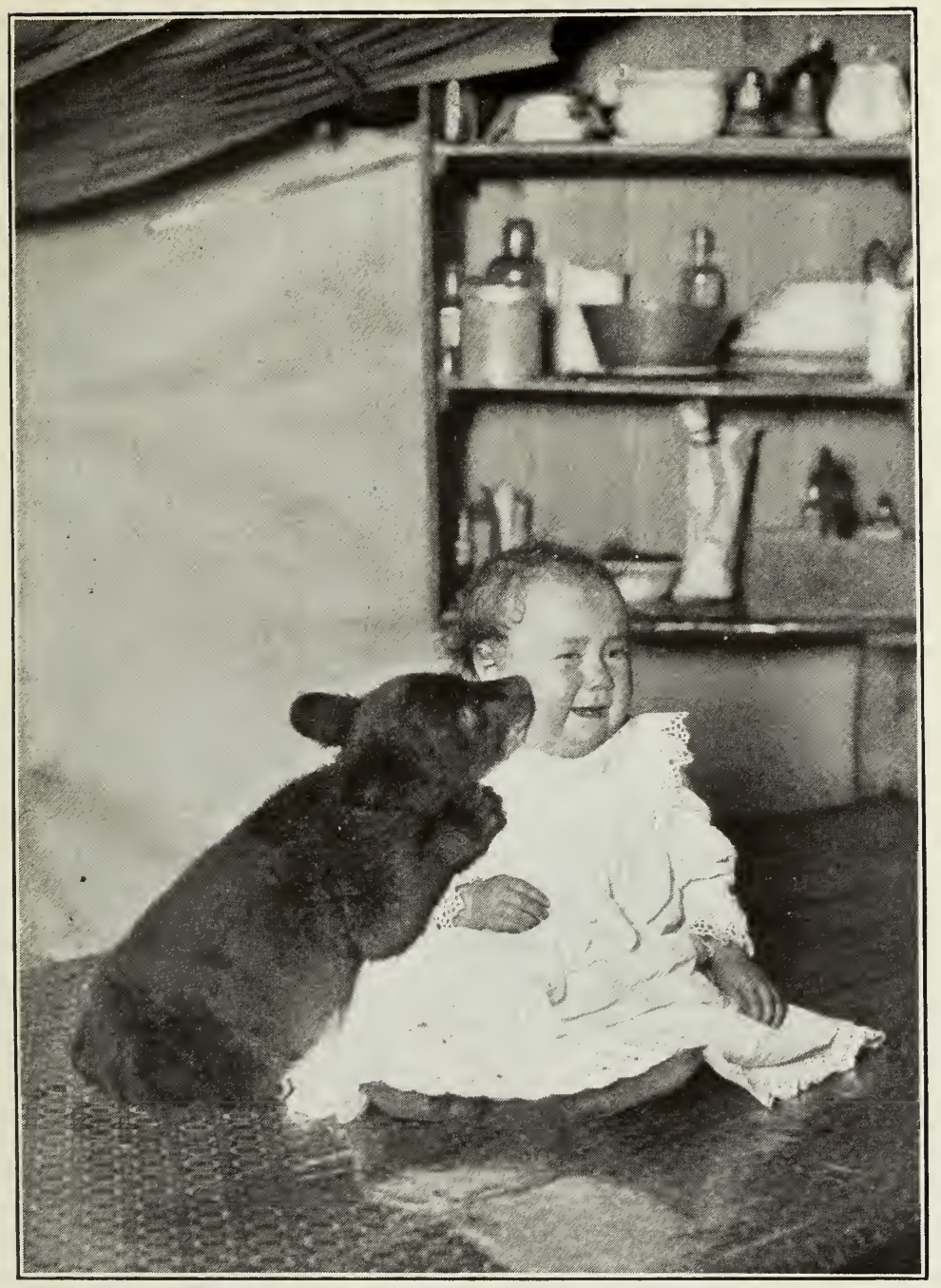

Bruno bids good-bye to Ursula 



\section{THE BEAR MAKES A JOURNEY}

Bruno crept up to her, and affectionately putting his forepaws up on her shoulder, placed his soft little muzzle against her cheek, making, as he did so, a curious pathetic murmuring sound, as if to comfort his sister in her hour of trouble.

Good-byes were said, and the cub was put in the packing-case. The cook, with a solemn face, came out to take a farewell look at him. Mrs. Weldon, too, came forward from the door, but she never reached the wagon. With tears in her eyes, she turned about and disappeared within the cabin.

Comrade and I felt like kidnapers as we drove out of the clearing into the rough lumber road, but our attention was quickly called to other matters, for serious trouble immediately developed in the packing-case. Bruno had never been shut up in this way before, and he did not intend to submit to his imprisonment without a vigorous protest. Right away he began to howl and rush about. Our wagon jounced into a hole, and the cub rolled over and over into a corner of the box. Immediately he lost his temper and commenced to growl and snarl, making a guttural noise for all the world like a drunken sailor cursing the universe. One of our wheels bumped over a rock, and Bruno shot like a rocket to the other end of his cage. Wild with rage, he began to bite his paw. This particular paw gave 
him no immediate relief and, still mumbling and cursing, he bit all his paws one after another. There seemed to be nothing that we could do to relieve the situation. We knew that it would hardly be safe to take him out of the box in his present frame of mind and carry him in our laps, so we jounced along, the air filled with smoke and general distress.

Before we reached the smoother road on the main highway, Bruno grew a little weary; and as we stopped for a few minutes to rest the horses, I gathered some ferns and dry moss and endeavored to make a bed for him. He accepted it in the spirit in which it was given, and a little later, after we had bounced out of the wood road, he made the best of a bad bargain. Though still murmuring and plaintively complaining, he curled up in a corner and went to sleep.

From Gordon's camp in Aroostook County to my camp is about fifty miles, and late that afternoon we put up at a small country hotel. In the stable was an unoccupied box-stall. Into it I put some hay - and Bruno was furnished with a grand apartment for the night.

It was astonishing how quickly the news of the bear's arrival was passed about. Long before dark that evening a crowd of men and boys, and not a few women, were besieging the box-stall. The 


\section{THE BEAR MAKES A JOURNEY 6I}

stable-keeper, a loquacious individual, was in his element : at regular intervals he retailed the story of the bear's upbringing, and between times he suggested to me that an admittance fee ought to be charged - in that way I could get enough cash to pay for our board and lodging!

I was a little worried about Bruno's food. Mrs. Weldon had warned me that he was particular about his meals. It seemed that, since he had been weaned, he had always fed from a little wooden trough that they had hollowed out from a small tree. He was insistent about this. $\mathrm{He}$ wanted everything primitive and simple. Cups, saucers, or bowls he refused to countenance. Knowing his peculiarities on this subject, I had brought some condensed milk and the trough along with me. Diluting the milk with warm water and adding some bread, I now offered Bruno his supper.

We had a large guest-list at the banquet. A solid row of heads and shoulders lined the top of the enclosure. Suddenly a shout of surprise and delight arose from the audience. Gingerly the bear had sidled up to the trough. He seemed suspicious about something. He put his nose down and gave a sniff. Then, "Whoof," he said, and up went his paw and slam, rattlety-bang, over and over, went the trough, and away went the milk over the floor. The crowd laughed, yelled with joy, and made remarks. 
"He don't want any plain grub like that, mister. Give him an oyster stew !"

"Say, boss, what he needs is beefsteak and onions, with French fried potatoes on the side. $\mathrm{He}$ ain't any ordinary no-count bear. I kin tell by his shape. He's a high liver. Say, I bet yer, he'd tackle a mince pie real strong."

Meanwhile Bruno had gone into a tantrum. Off in the corner he was growling and grumbling and biting his paw. I was embarrassed and humiliated, and much perplexed to know what to do.

The spectators seemed rather to enjoy my discomfort. Luckily I had a number of cans of milk with me, and after the cub's rage had subsided somewhat, I prepared another supper and filled the trough again, this time using less water and adding much more of the sweetened milk. I then placed the food in the centre of the stall, stepped back to avoid another milk-shower, and awaited results.

A hush of expectancy came over the crowd. I could hear the hens fussing about in the yard. Barn swallows were flying in and out through the big open door, twittering and calling to one another, as if a little perplexed at this unusual gathering in their sanctuary. Again the cub, with much caution, stealthily approached his supper. His eyes rolled about and his upper lip protruded and wagged from side to side in a curious and gro- 


\section{THE BEAR MAKES A JOURNEY}

tesque way. There surely would be serious trouble this time if everything was not all right.

"Look out, mister!" yelled one of the onlookers. "Git out yer umbrella; it's clouding up. There's going to be another shower."

But as Bruno sniffed again at the mixture, a tranquil expression came over his countenance. Another smell, and into the trough went his right paw. Was he going to upset it? No, down went his nose, up to his eyes in the milk. With his lips pressed tightly against his paw, he began to feed, making a curious sucking humming noise, like the drone of a small electric motor. The concoction seemed to please him.

"Say, he's a regular suction-pump now he's got a goin'," volunteered one of the spectators. "Watch him swell up, will yer."

"Stan' back, stan' back!" warned a little old man with a gray whisker-tuft on the point of his chin.

"Shut yer noise," laughed the hostler. "He ain't goin' to bust. There's no danger, ladies. He's just takin' a rest."

Suddenly Bruno pulled his head out, licked his chops for a moment, then wheeled rapidly round to the other end of the trough, and again sucking his right paw with the same musical purring accompaniment, finished his supper. 
"Show's over fer the night," announced the hostler. "Next performance will be at seventhirty to-morrer mornin'. Buy your tickets now and avoid the rush!"

The next day we continued our journey, and about noon came to the highlands that overlook the valley where lie the Schoodic Lakes, which form the headwaters of the St. Croix River. Stretching south, far into New Brunswick, lay an unbroken forest.

Our camp stands in an open field some distance above the shore of one of the smaller lakes. Quite near it are a farmhouse, several farm buildings, a club house and a number of small camps. All were under the management and watchful care of the farmer, a genial gentleman of the old school, called by his admiring sportsmen friends, "the squire." Visitors at all the camps and the club house get their meals at the squire's.

The open land of this little settlement is surrounded by woods, which at that time were well peopled with the usual wood-folk of the Maine forest. Deer were plentiful; the woods were full of porcupines. Foxes and raccoons were often seen. Black bears frequently came into the clearing and worried the sheep. Mink and otter frequented the shores of lakes and brooks; and often in the summer-time the moose came in to feed on the lily-pads 


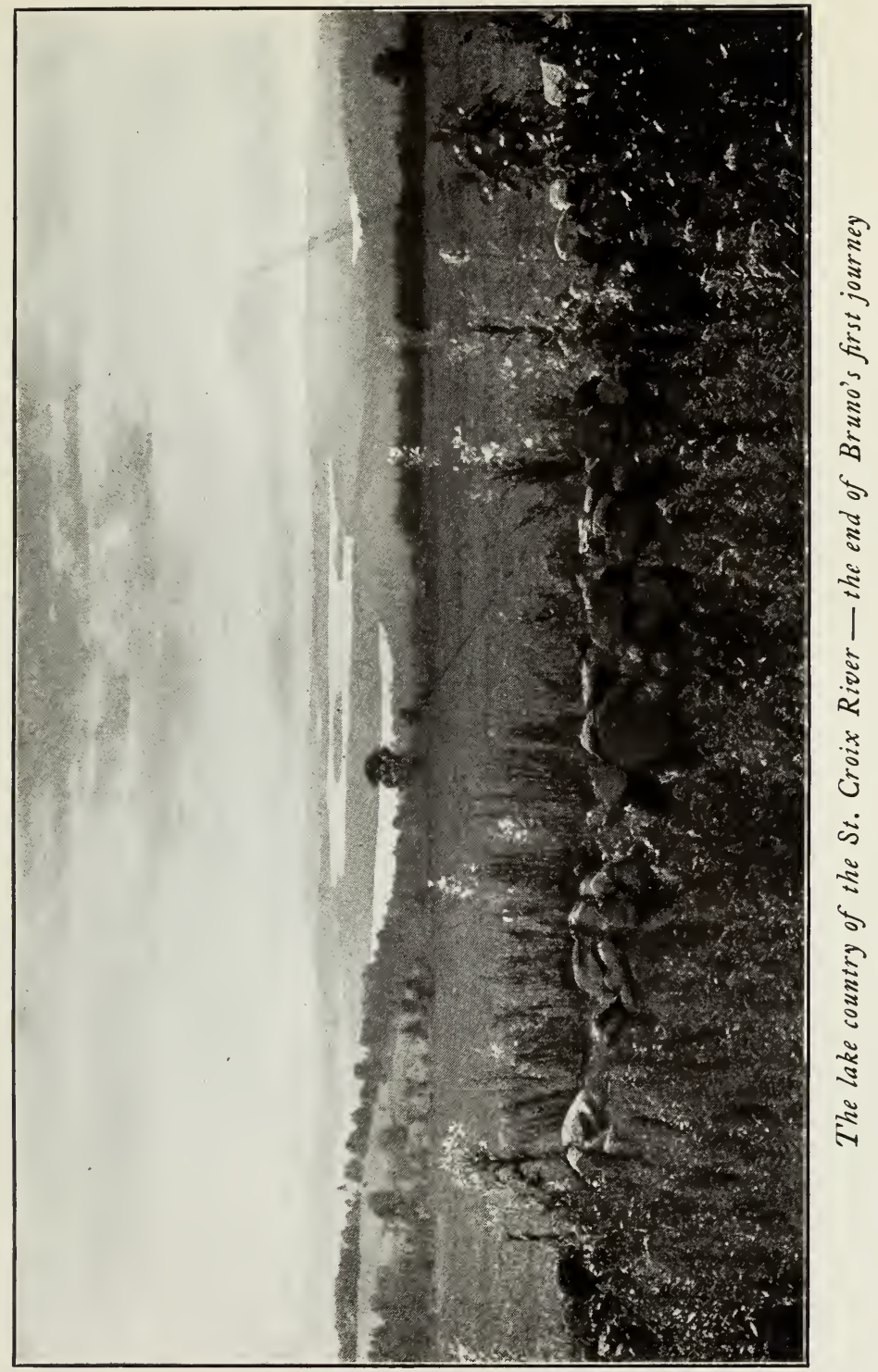





\section{THE BEAR MAKES A JOURNEY 65}

and aquatic roots along the margins of the deadwater streams.

Here in the land of his fathers Bruno was to live with us for a few weeks, and become accustomed somewhat to the ways of city-folk before saying good-bye to his forest home. Fortunately, the day after our arrival there came a change in the weather. It began to rain, and for seven days, with only an occasional let-up, the downpour continued.

We felt much easier now about the Weldons. The people at the village had told me that they really were in great danger and should not have been allowed to stay in the woods. I was relieved in a few days, when a letter came from the lumbercamp. They had had a narrow escape from being burned out the day after we left. All that day, while burning brands and bits of bark continually fell upon the roof and in the door-yard, they fought the fire. It was only by constant vigilance and the utmost exertion that they kept the flames in check until the rain came in the night. They missed Bruno very much, and were anxious to know how he was getting on in his new home.

For several days the storm kept us indoors. This was particularly fortunate for the bear, for it gave him a chance to become acquainted with us. If, as is usually our custom in fine weather, we had gone forth in the morning, not to return until night, the 
cub would have been a lonely desolate animal. As matters now stood, he immediately became one of the family, and he quickly made himself quite at home. He followed us everywhere about the camp, but seldom went outdoors unless we accompanied him. If it ever happened that he was left outside, he would soon appear at one of the lower windows, and within a day or two he had torn off all the mosquito netting from every opening.

To make up for this defect, however, he did his best to destroy the flies which he had let in. $\mathrm{He}$ was one of the best little fly-swatters in the modern campaign to keep down these pests. On the inside of the camp he made frequent visits to all the windows, killing the flies and eating them with great relish.

The question of Bruno's food was one that had caused us some worry. As there were several cows on the farm, and our supply of condensed milk was becoming greatly reduced, it seemed most proper and right that Bruno, from now on, should be served with the real article for his diet. He ate his first meal with much zest. I had prepared it most carefully, sweetening it with sugar and heating it to just the right temperature. Now as before he viewed the repast at first with some distrust. But presently his right front paw was brought into 


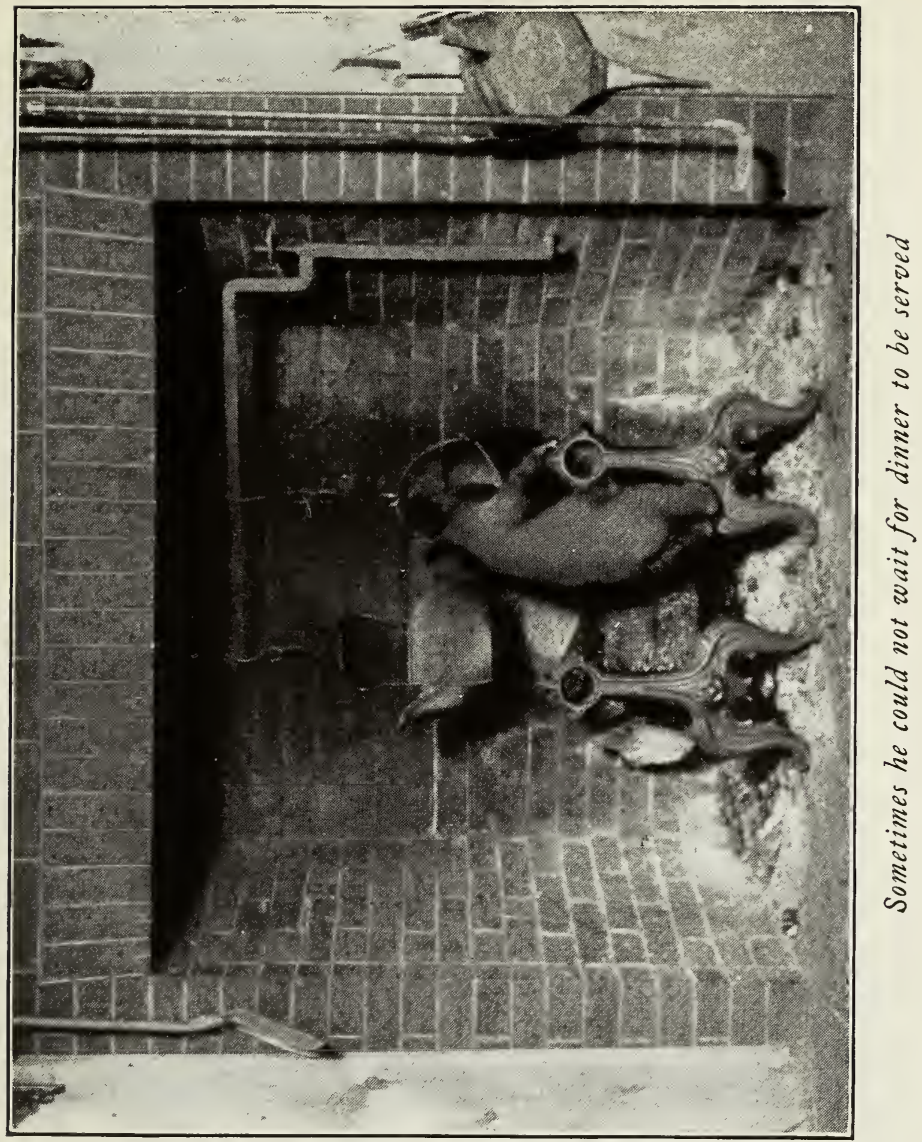



service. Again he whirled from one end of the trough to the other, and to the same accompaniment of droning music the milk quickly disappeared. When it was all gone, he seized the side of his wooden trough with his teeth and, growling and complaining, shook and rattled it over the floor. $\mathrm{He}$ seemed still to be hungry and I served him again, though where he could manage to stow away so much milk, I could hardly see. Already his chubby body had taken on the shape of a fullblown football. But his appetite proved to be greater than his capacity, for just before he reached the bursting point, with the milk only half gone, he had had enough.

Presently he toddled across the floor, climbed heavily into my lap, and went to sleep. But he was n't comfortable. In a short time he commenced to twitch. Evidently he was having a bad dream. Perhaps all was not well inside. Soon he moaned, then suddenly he woke up, looked wildly around, and began to scream.

Something serious was happening. He kicked and scratched, and I put him on the floor. He suddenly seemed to have grown larger, and to have taken on the shape of a round toy balloon. It was colic, and he was wild with pain. He bit first one paw, then another, and finding no relief in this expedient, he made a grab for my ankle, just 
missed it, and set his teeth in the bottom of my trouser-leg. There was good material in that cloth, and, though he shook it savagely, it held firm. From a point of safety in the background, Mrs. Underwood pulled his tail, and my clothing was saved.

Right here we learned a most valuable method of diverting Bruno's mind when for a moment an attack of brain-storm chanced to be upon him. His tail, though very small and insignificant, seemed to be the most sensitive and vulnerable point of his anatomy. If he were in mischief, touch his tail and immediately he was on his good behavior. If he were asleep, touch his tail - he was wide-awake and in action in a second. In fact, this posterior appendage seemed to serve him as an electric bell or signal, which had connections with all his various activities. Whenever it was touched, it called for immediate action. You pressed the button and he did the rest.

Since we had no medicine for colic in camp, nature had to take its course. Gradually the pain wore off, and Bruno was himself again. One experiment with cow's milk was enough, and I sent at once to the railroad and telegraphed to Boston for a case of condensed milk.

The bear was a born investigator. He wanted to know the why and wherefore of everything. $\mathrm{He}$ 


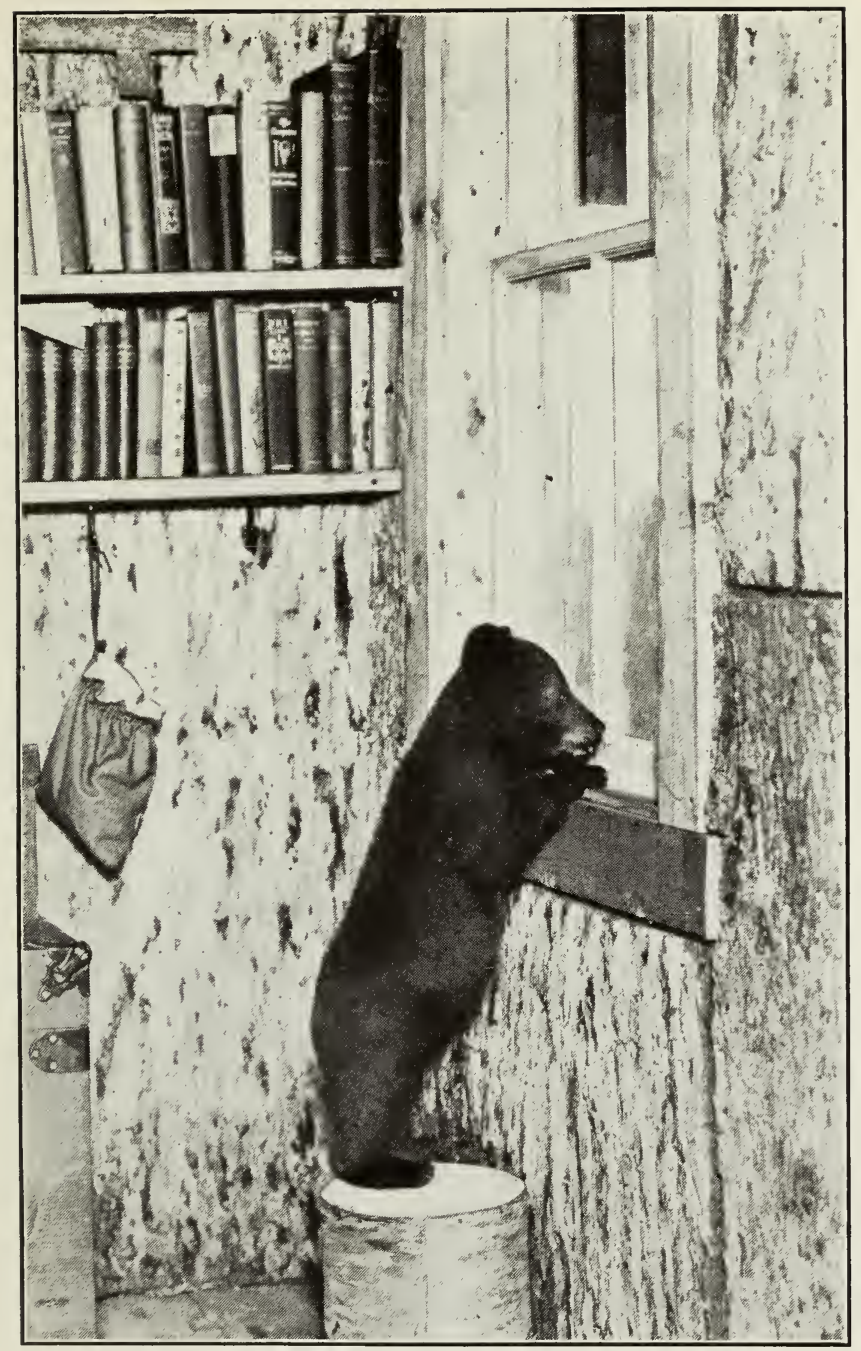

The cub looks out on the wide, wide world 

was like a monkey; he could pull out a drawer, and open a door if it were unlatched. Standing up on his hind-legs, he would whine and smell at the crack of the food-room door, and, unless it was latched, his long prying claws could open it quite easily. Nothing within his reach was safe.

When there was no fire burning, he liked to climb into the fireplace and up one of the andirons to the black iron pot that hung on the crane. With one paw he would tilt it over, and stick in his head, to see if by chance any food had been left there that might be to his liking. Sometimes in the evening, as I sat by the fire reading, the bear would shin up the back of my chair, climb to my shoulder, and slap the book from my hand; then, if he felt drowsy, he would climb down, curl up in my lap, and drop off to sleep.

We let him run about the camp pretty much wherever he wished. One place, however, he was supposed not to enter - the sleeping-room. But whenever he was missing, we could be almost sure of finding him there. One day from this forbidden room there came a dismal howl of pain. I ran to the door, and sure enough Bruno was in serious trouble. He had jumped from the chair to one of the beds; then, mounting the post, he had climbed to the shelf overhead. On this shelf I had left some fishing-tackle - a long gut leader, with three fly- 
hooks attached. One of these flies, a red ibis, claimed the bear's attention at once. He was interested in flies. They were good to eat, and if insignificant little house-flies and blue-bottles were appetizing, this great glorious scarlet insect should be delicious. Forthwith he snapped up the ibis. It caught in his tongue, and he fell to the floor.

As I looked in, a wild and painful sight greeted my eyes. One of the hooks on the other end of the leader had caught in a crack in the floor, and Bruno was doing a circus act. Held fast by the strong gut leader, with his tongue stretched far out beyond his nose, he swung round the circle in mad haste, howling with rage and pain. What to do I did n't know. Angling is a favorite pastime of mine, and in the pursuit of this sport I have hooked many strange fishes; but here was a catch that was new; I had never had a bear on a hook, and now that I had one on, the question was how to get him off! It would certainly be a dangerous operation to extract that fly - like fooling with a buzz-saw.

If we could only quiet him a bit and divert his mind. Comrade suggested that I begin on the end farthest removed from the seat of trouble - that sensitive point, his tail. A brilliant idea; but it could n't be carried out. Bruno was revolving so fast that this member could not be reached. How could we check his wild career? Happy thought: 


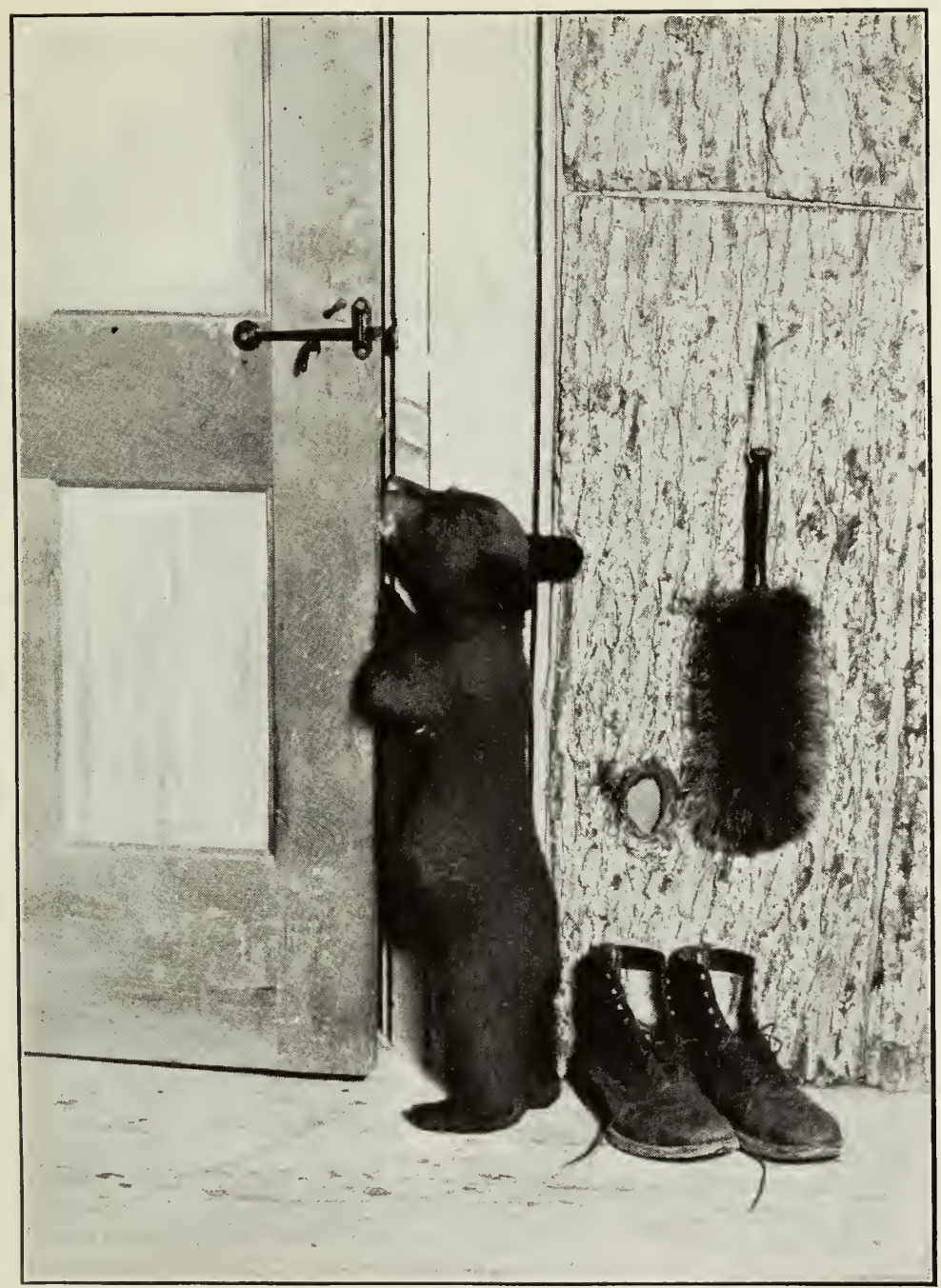

If we left the door unlatched, Bruno had no difficulty in opening it 

the landing net! If he wanted to play fish, he must submit to the rules of the game and end the struggle in a net. I was just going after one, when suddenly my fish changed his tactics and began to back water as it were. His tongue stretched out like an elastic band, until it seemed to be just at the point of snapping or coming out by the roots - and then the hook let go and the situation was saved. For a few days the cub had a sore mouth, but the wound soon healed and bothered him no more.

Bruno seemed to have an interest in everything that interested me. He was always glad to be around when I was taking photographs, and was especially interested in the red rubber bulb on the end of the long tube that worked the shutter of my large camera. It was soft and yielding, and he liked to bite and pull upon it. If in his play the camera fell to the floor, it never worried him in the least; it only added zest to the sport. To keep the bulb out of his reach, I wound the tubing round the lens, and thought that I had got the best of him. But Bruno was not to be so easily foiled; he soon discovered that he could get the bulb by climbing up one of the legs of the tripod.

When I came back into the room one day, I surprised him in the very act of beginning this performance. He had been walking round the base 
of the tripod, looking for the bulb, and had just discovered it when I appeared. With another camera focused upon him, I shouted abruptly, to stop him; and in the picture that I took, his expression indicates that he is alert for any emergency - to turn and run, or stand and dodge a boot or bootjack or anything that might come his way.

When we went to the farmhouse to get our meals, Bruno generally followed along behind, although he usually encountered adversity in the form of a brown spaniel that lived on the farm and that loved to plague him. The pathway was lined by a row of hardwood trees planted at regular intervals. From behind one of these the dog would sometimes rush out, and the cub, yapping and snorting with fright, would gallop to a place of safety and, like a cat, shuffle up the next tree in line. After this trick had been played upon him several times, Bruno took no further chances, but climbed each tree in the row as he came to it. From a point of safety some ten feet above the ground, he looked for his enemy, then darted on to the next haven when the coast was clear.

While we were in the dining-room Bruno spent most of his time playing with the children in the kitchen and the woodshed. Here occasionally he fell in with his enemy the dog. Brownie, the spaniel, had no desire to hurt the cub; he wanted only 


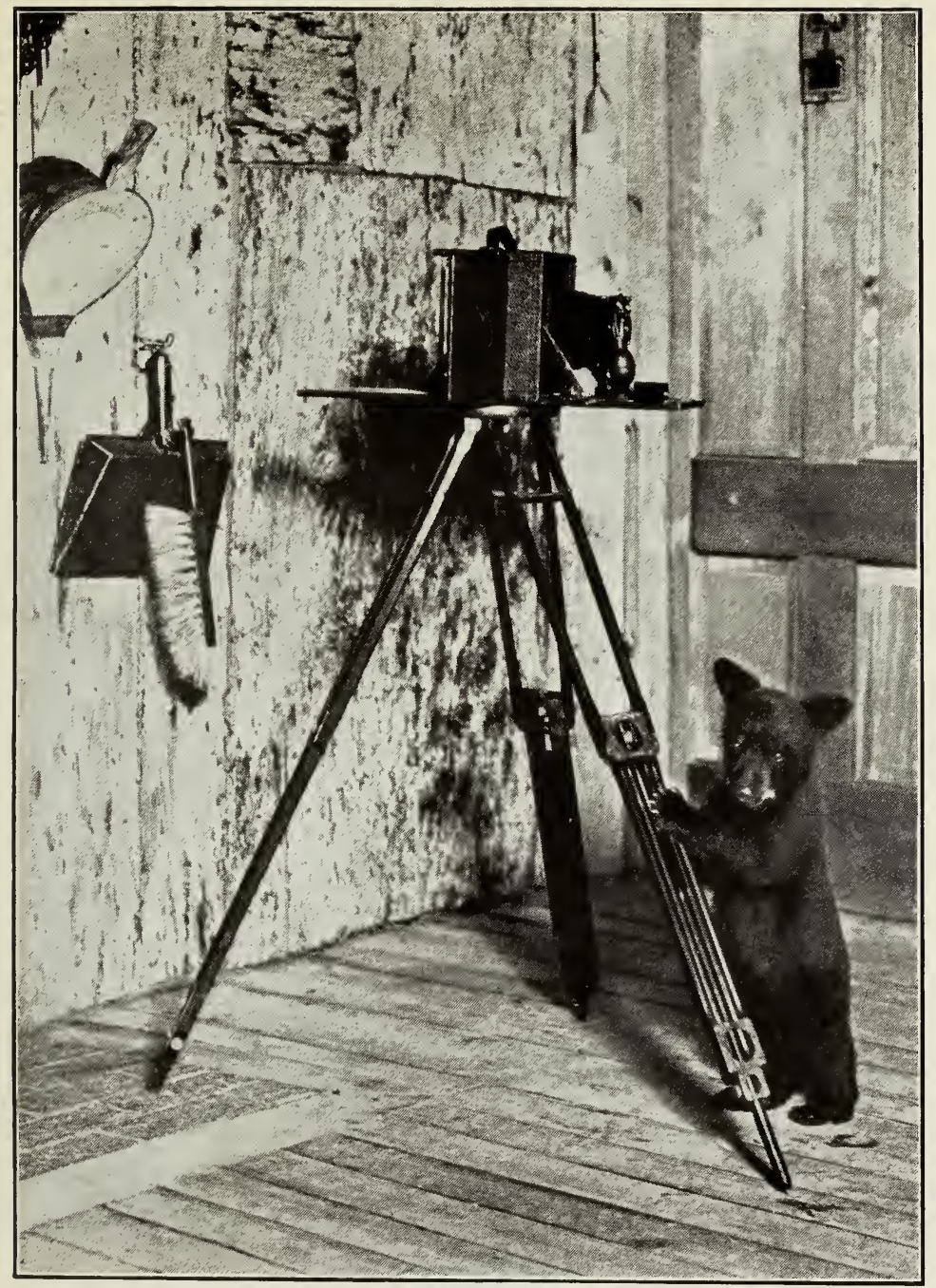

Caught in the act - an interrupted climb after the enticing bulb 


\section{THE BEAR MAKES A JOURNEY 73}

to play with him and be friends. The bear, however, sought no friendship with any of the lower animals; he was a snob in this respect, and held himself quite aloof from all ordinary creatures. Men and women were his associates; all others were as dirt beneath his feet. Brownie resented this attitude when Bruno was in the kitchen; for this was his domain, and he would brook no toplofty mannerisms from any unbidden stranger. With a rush and a menacing growl, he would drive the bear into a corner or behind a chair, where Bruno, standing straight up on his hind-legs, with his fore-paws swinging freely in defense, would hurl defiance at his adversary. With his chest expanded and his breath coming forth in explosive gusts as he champed his frothy lips, he seemed twice his natural size and presented to his foe an aspect most forbidding.

The cub and the spaniel never really came to blows, however, for both, like schoolboys at play, were usually bluffing. If one got serious and meant business, the other generally backed down. Before our outing was over they developed a better understanding of each other, and, though they never became loving friends, they called a truce and ceased all annoying practices.

One morning while we were at breakfast, and before the armistice had been declared, Brownie 
had hustled Bruno out of the kitchen into the pantry where, behind the sugar-barrel, he held his ground. The dog, having shown his authority and satisfied his peace of mind, retired to the door-mat out in the sun.

Bruno alone in the closet, all danger past, began to investigate. To his keen nostrils the air was redolent with delectable odors of food - sweet and subtle smells, the like of which he had never dreamed of before: spices and cookies, doughnuts and cake. His lips quivered and his mouth watered. The overpowering fragrance that filled the little room was fairly intoxicating. There was so much to choose from! Where should he begin? Quite near at hand was a scent that was old and dear to him, a smell that took him back to his cabin home in the woods.

In a moment he had mounted a cracker-box, and reaching up to the top of the sugar-barrel, he looked within. Never before had he beheld so glorious a sight. "Linked sweetness long drawn out." A world of sugar, and this world was his! Without a moment's hesitation he fell headlong into the snowy whiteness down below. Here, only a few minutes later, fortunately, he was discovered. His speckled, frosted face and paws gave mute evidence that he had enjoyed to the utmost his hurried banquet in the barrel. 


\section{THE BEAR MAKES A JOURNEY 75}

One morning there was great excitement about the camp. During the night there had been a tragedy on the farm: a relative of Bruno's had come down from the mountain into the pasture, killed one of the squire's sheep, and gone off with the carcass. There was blood and wool on the ground where the deed had been done, and from this spot a trail of down-trodden grass showed where the bear had dragged his victim into a thicket. Here the earth was torn and trampled and soaked with blood. A few ribs and the bones of the legs lay scattered about, and near-by we found the pelt of the sheep done up neatly into a roll with the wool side out. The bear had skinned the sheep, quite as a man would have done, before he carried off the meat. He must have been disturbed at his work, for some distance away in his flight he had dropped and left in his tracks a good hind-quarter of mutton.

Thinking that old Bruin would come back in the night for the rest of his plunder, the squire set a bear-trap and used the meat for bait. But the bear was too wary or too well satisfied with what he already had taken; for though the trap lay a long time with its powerful jaws open to receive him, he failed to return for what he had left. That he and perhaps several other bears were still in the neighborhood was evident: a few days later we 
learned that eleven sheep had been killed in one night on a farm about five miles away from our camp.

Bears are quite plentiful in some sections of Maine, especially in our region, which borders on the wild lands of New Brunswick. On our trips back into the woods, when we went some distance from the little settlement, we often saw their signs. They are very fond of the big black ants, which live in nests in rotten trees. Frequently one finds these ant-trees rent and torn asunder by the bears' powerful claws. In the spring their big tracks may be seen along the margins of the waterways that connect the lakes. Here, where the sluggish suckers gather by the thousands at this season, to spawn, the bear comes in for a fare of fish. Here also he hunts for frogs, of which food he is very fond.

To the lumbermen Bruin is a pest. He never hesitates to break into an unoccupied lumbercamp if any food has been left behind. In many of the camps, especially in New Brunswick, the supplies for the year's operations have to be brought in on sleds during the previous winter, the only time when transportation over the rough trails is possible. During the summer the empty lumbercamps are sometimes used as storehouses - bearhouses, they are often called. In these places many 


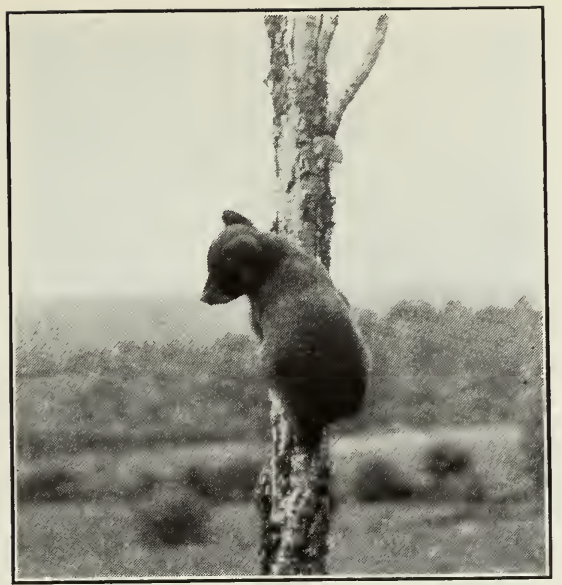

Watching for his enemy, the dog

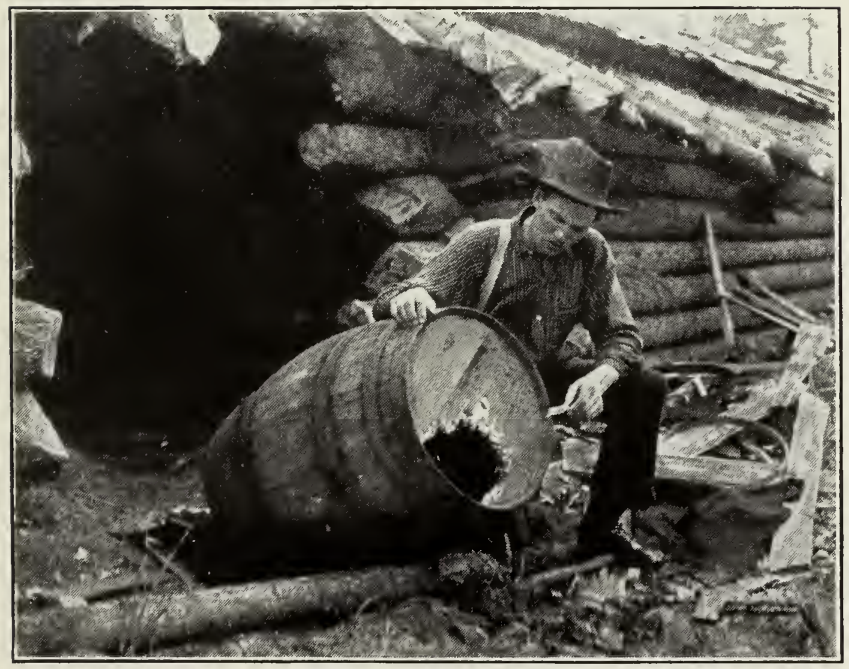

One of Bruno's wild relatives broke into this cask and dipped the molasses out with his paw 

barrels of pork, flour, sugar, and molasses are put away for safe-keeping. Windows and doors are boarded over and securely fastened, as a protection against marauding animals; but in spite of these precautions, the bears sometimes break in and steal.

We found such a place one day in the woods. The black rascals had torn off the boards from the log-house door and had rolled out a puncheon of molasses. With their sharp teeth and claws they had broken a hole through the tough oak head and with their paws had dipped out every drop from the cask. Now that we had an opportunity to observe at close view the sagacity of little Bruno, it was easier for us to understand how his wild brothers could be such ingenious thieves.

One noon, on the shores of the lake, as we were preparing to "boil the kettle," I had a surprise. Joe, our Indian guide, coming out from the bushes where he had gone for dry wood to kindle our fire, made an announcement. "One big black bear, he been killed here day before yes'day."

On the other side of the point of land from where we were lunching, Joe had found a deserted camping-place that recently had been occupied. Beside the fireplace he came upon the skull of a black bear, and near-by, on the ground, lay the big forepaws of the animal. These he now held up to my view. 
"Maybe he the feller that stole molasses," he volunteered.

We were picking up our things after lunch, for we were on our way back to the settlement, when I saw Joe drop the bear's paws into a bag that he often brought with him for the storage of odds and ends.

"Those are n't of any use, Joe," I remonstrated. "Why are you going to take them home?"

"Maybe you see by-em-by," he chuckled.

Early in the morning the day after our return, the squire came down to the camp in great excitement. A "busting big bear," he told us, had come right up in to the cow-yard behind the barn during the night. Tracks in the damp ground had told the story.

"Yes, sir, he even had the nerve to drink out of the cow's trough," said the squire. "Come, Joe, you set the trap, this time. I'm going to butcher a sheep to-day and I'll give you plenty of bait."

Everyone about the place was aroused. It was time something was done. This daring beast must be taught a lesson. He had killed a sheep, and now evidently he wanted a calf. What next? Someone suggested that perhaps Bruno's presence had something to do with the bear's impudence. We all went down to the barn to view the tracks. Yes, there they were, and big ones too, and plainly stamped for all to see. 


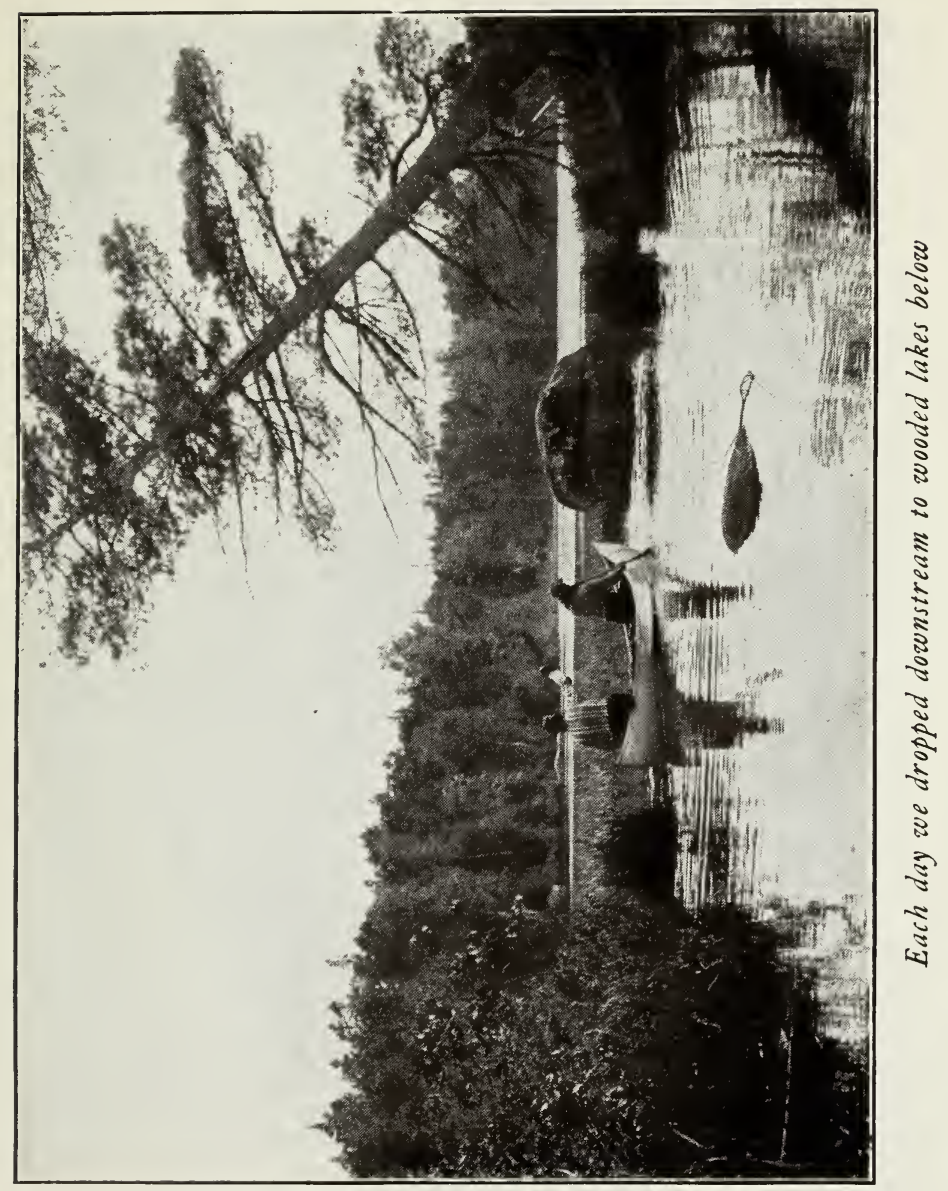





\section{THE BEAR MAKES A JOURNEY}

"That funny bear," Joe whispered to me. "All time he walk on front legs. You notice it?"

Yes, on further examination there did seem to be a great similarity in all those footprints. Joe was laughing now. "I guess no use set trap." Then, giving me a nudge, he continued, "Those bear's paws I found him yes'day. You know it. I use um early this morning. Don't say a word."

It was a good joke, and the squire appreciated it as much as anyone when finally I told him how Joe had found and used the dead bear's paws.

All too swiftly our outing days flew by, and the time soon came when we must return to city ways again - a necessity that meant for Bruno a final farewell to his native woods and the beginning of a new and interesting life. 


\section{CHAPTER V}

\section{BRUNO IN BELMONT}

BRUNo's journey in a big box in the baggage-car was uneventful, and in due course he arrived safely at our suburban home in Belmont, a few miles outside Boston. Here the bear found everything to his liking. At night, and when not in company with some member of the family, he stayed in his quarters in a box-stall in the cowbarn; but generally, throughout the daytime, he roamed wherever he wished about the grounds. Our country place comprises several acres and, together with the adjoining homes of my brothers and nieces, provided Bruno with a considerable amount of territory in which to exercise and play.

There were trees to climb, a brook to wade in, and a small pond where lived a colony of frogs. But best of all for the bear, when he grew older, were the gardens with vegetables, fruit, strawberries, cherries, raspberries, and currants, all for his choosing. It was some time, however, before he gave up his diet of condensed milk with bread and water. He still insisted on feeding from the wooden trough of his childhood, and he still had the habit of plunging his nose up to his eyes in the sticky milk. 


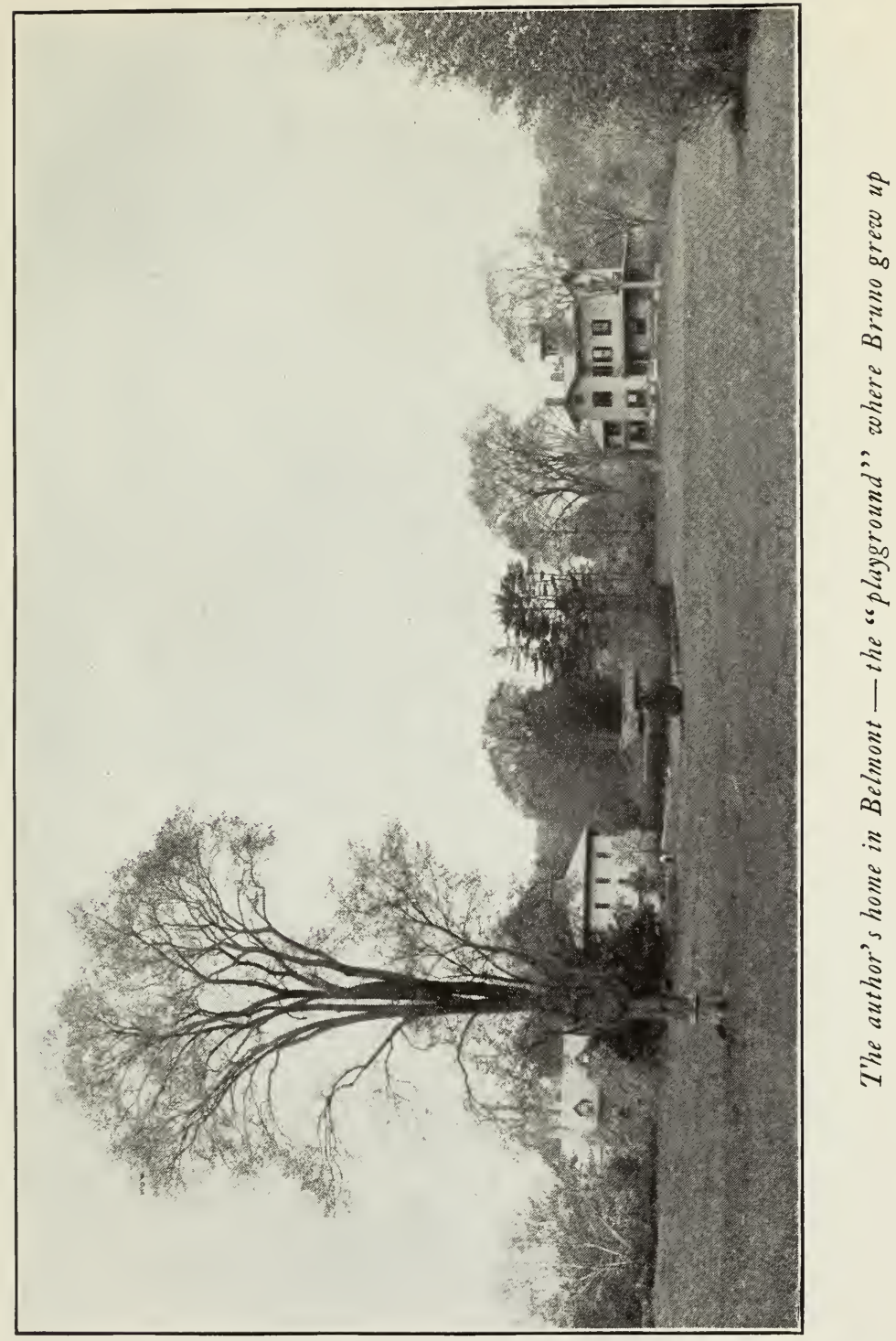



Toward midsummer, when the cub was seven months old, there came a very rapid change in his appearance. His brown woolly coat was soon hidden beneath a heavy growth of straight black silky hair. This outer fur first made its appearance as a dark line down the middle of his back; then quickly it spread, until it covered his whole body and he became a typical black bear.

One day, as he played about on the lawn, he came across the shining brass nozzle of a garden hose, propped up on a stick in the grass. The valve had been partly shut off and only a small trickle of water gurgled forth from the opening. Bruno approached it cautiously a step at a time, twisting his head and viewing it first from one angle and then from another. The noise of the stream seemed to give him the idea that the thing was alive. I was standing at the farther end of the hose, and when at last he reached the nozzle and put his paw out to investigate, I turned the valve full open and the stream rushed forth. Instantly the bear recoiled and, standing upright, looked with astonishment at the spectacle of water running up hill. Never had he seen the like of this before. When he grew older, he learned to admire the cool flow of water.

On a hot day in August he loved to sit on the lawn and let the gardener play the hose upon him 
and souse him from head to tail. Only when the stream struck him full in the face and eyes, did he rebel. Then, snarling, growling, and dabbing with his paws at the water, he would turn tail and run.

During his first summer Bruno was usually given a bath every day by Mrs. Underwood, who had gladly volunteered for this work. The cub developed a liking for these regular ablutions. Comrade, wearing a rubber apron, used to take him in her lap and administer the soap and warm water with a large sponge. To dry him (and this part of the operation was the bear's special delight) a woolen blanket was brought into use. Comrade held it by two corners in front of her, and the bear would come bounding up on the run and jump into the middle of it. Instantly the robe was dropped over him and he would tumble about, end over end, first in one direction, then in another. He enjoyed this mad romp immensely. It dried him somewhat and gave him exercise. Later this game brought us into trouble. Bruno came to regard a large piece of cloth held up in front of anyone as an invitation for a "rough-house" frolic. We were mortified one day when, as a lady was approaching the house to make a call, Bruno came romping across the lawn and with a joyous bound jumped squarely into the folds of her clean white dress. Apologies were in order, and the cub was readily 


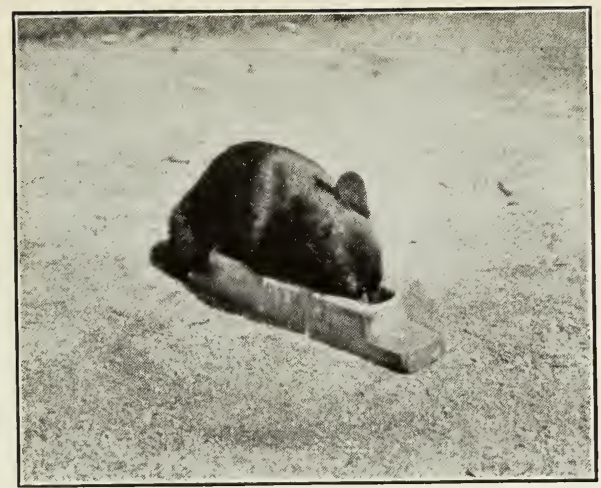

He still insisted on feeding from the wooden trough

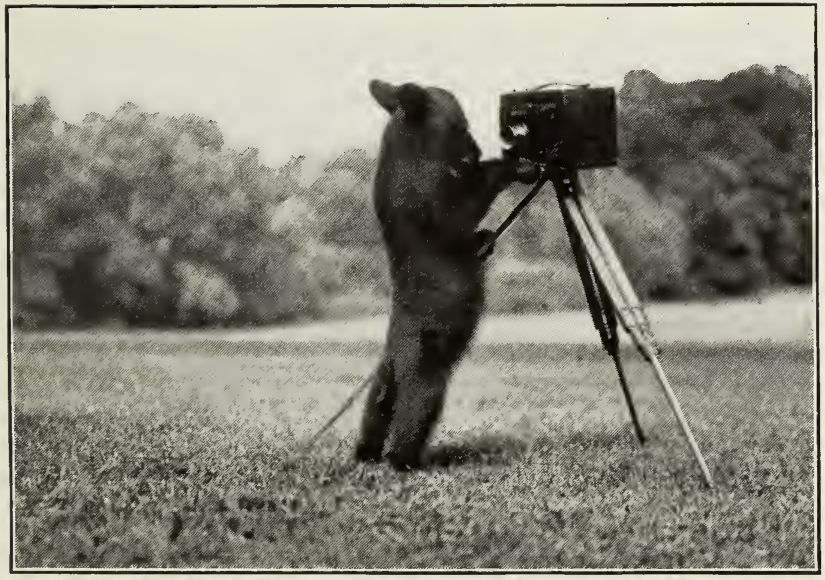

Bruno was willing to have his picture taken, but he wanted to examine the camera first 

forgiven when it was explained how it had happened.

Although he was fond of sponge-and showerbaths, he never could be persuaded to go into the pond for a swim. He would run and play on the shore, but he seemed unwilling even to put his feet into the water. I forced him in one day, and the result was somewhat disastrous.

He was standing on a rock, looking down intently into the water, watching a big fat pollywog that was wriggling about just under his nose. Silently I crept up behind him, and with a push on his tail shoved him forward. Quick as a flash he turned end for end, and before I had withdrawn my hand he had bitten me on the thumb. In an instant, hardly wet from the plunge, he was back again on the grass, making for my ankle. As mad as a hornet, he rushed at me. Three times I was obliged to push him off with my feet, and the last time I rolled him end over end. That seemed to bring him to his senses. He played dead now, and lay for a time very still on his side, narrowly watching me all the while from the corner of his eye.

Luckily these bursts of temper never lasted more than a few moments. Like a summer shower they were soon over, and all was bright again; and he never harbored any resentment for the many chastisements I was obliged to give him. 
Though Bruno recognized me as his master, he always went to a woman if frightened or in trouble. Evidently he never forgot that to a woman he owed his life. If a big dog came in sight and Mrs. Underwood was anywhere about, he would leave me and run to her for protection. If she was nowhere to be seen, he would turn to any woman whom he happened to see. He was evidently a ladies' man. Even a female voice had an attraction for him. I have known him to leave me when I was playing with him, to run toward the sound of a woman's voice that he had never heard before. He was captivated by a petticoat.

Skirts afforded him a place of refuge in time of trouble. This characteristic of our pet (when unknown to our friends of the gentle sex who came to make his acquaintance) was sometimes the cause of considerable embarrassment. A mouse when seeking a hiding-place has been known to cause a serious panic in an audience of susceptible people. Imagine then the horror of a gentle soul who observes a bear rushing toward her feet, and sees him disappear beneath her garments. Such a situation is, to say the least, disturbing to a person of sensitive disposition.

One morning a lady who came down the walk pushing a baby carriage stopped for a moment to talk with me. Bruno, who was playing near-by, 


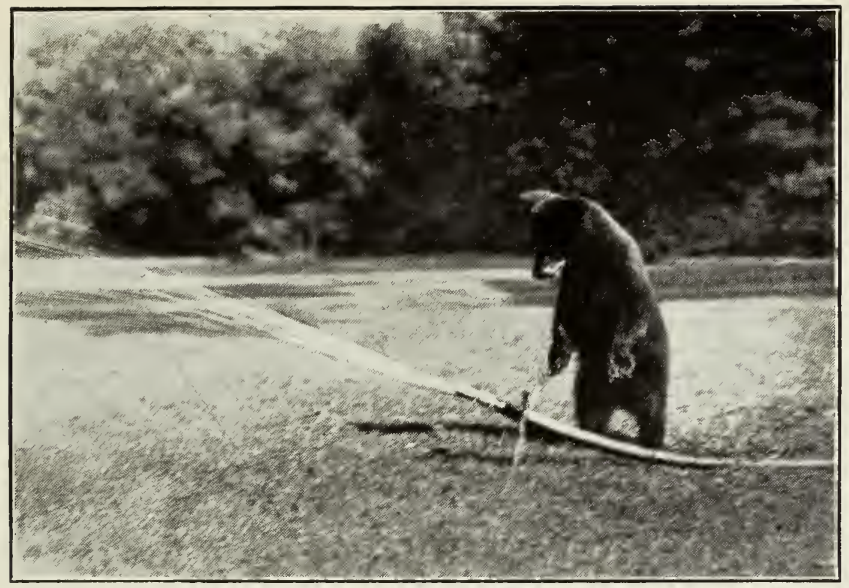

He is astonished to see water running up hill

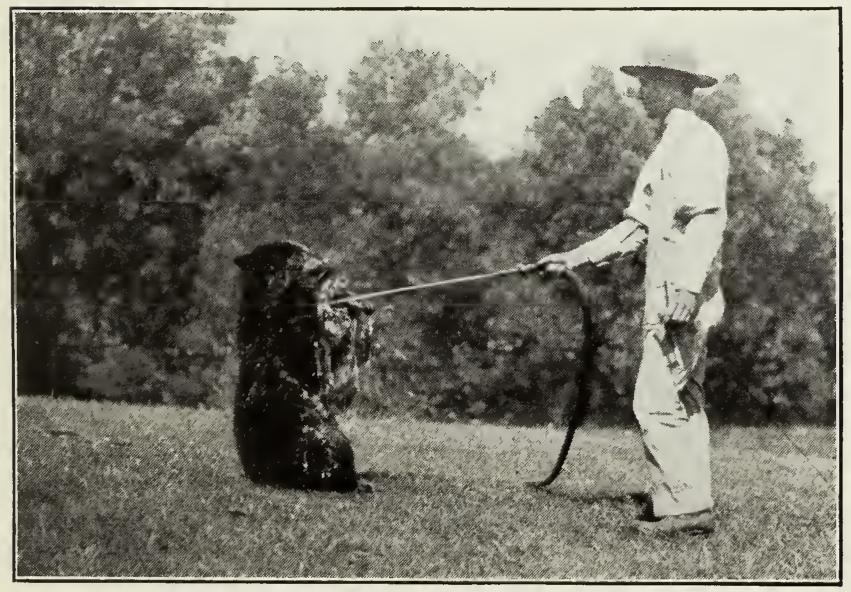

Who wouldn't like this on a hot summer day? 

suddenly became alarmed by a passing dog. Hearing our voices, he jumped over the wall and came running up the path toward the lady, his natural protectress. She, in great alarm, turned in her tracks, and pulling her child behind her, ran in the opposite direction. I too joined the procession, and tried to explain as I ran that there was no cause at all for alarm. The baby was the only one who enjoyed that situation; for her it was a frolic long to be remembered.

All the children on the place were fond of the bear and loved to play with him. Alice came over one morning, bringing her brand-new best doll. "Bruno," said Alice, with her sweetest smile, "don't you want to know my nice dolly, Sarah? Shake hands with her, Bruno. I hope you will like her."

The cub did seem to like her, though he did not shake her hand. What he shook was her head. Alice's smile changed instantly to a look of consternation, and her voice grew sharp and tense.

"Stop it, you naughty bear! Oh, see what he is doing! Oh, please, Uncle Lyman," she appealed to me, "make him stop it."

She was crying now, but it was too late for me to interfere. The bear had rudely snatched the doll from its carriage and was making off with it down the meadow. Alice, screaming in dismay, with her 
empty carriage bouncing up and down in front of her, chased after him. With some difficulty I rescued the doll. Its right ear was badly lacerated. Meanwhile the kidnaper had climbed a ladder where, from its top, he could view the havoc he had wrought.

By the last of October, Bruno had lost most of his first teeth and his second canines were growing fast. About this time his food disagreed with him, and for a while he became quite ill. His hind-legs seemed to be paralyzed, and at times he had great difficulty in walking. I was still feeding him on condensed milk, from his wooden trough, three times a day. Occasionally he foraged through the garden and found some things to his liking. Once I discovered him in the middle of a pansy-bed, picking and eating every blossom within reach. $\mathrm{He}$ was very fond of snowberries. Reaching up with his forepaws, he bent down the branches of the shrubs, and stripped all the fruit from them, devouring it with apparent relish.

The weakness in his hind-quarters grew worse and I finally consulted a veterinary, who advised a change of diet - less milk and more cereal foods, with plenty of fruit. The fact that the bear was teething may have had something to do with his condition; but at any rate the change of food brought the desired result, and Bruno was soon as well as ever. 


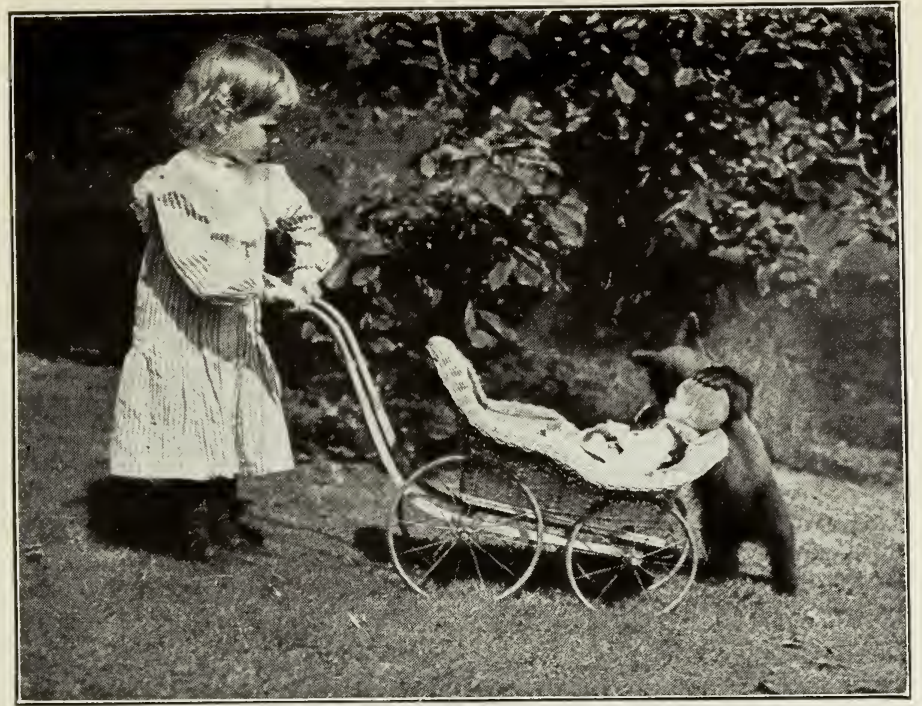

Bruno is introduced to a new arrival in the family. A moment after the picture was taken he kidnaped the "baby"

and ran down the meadow

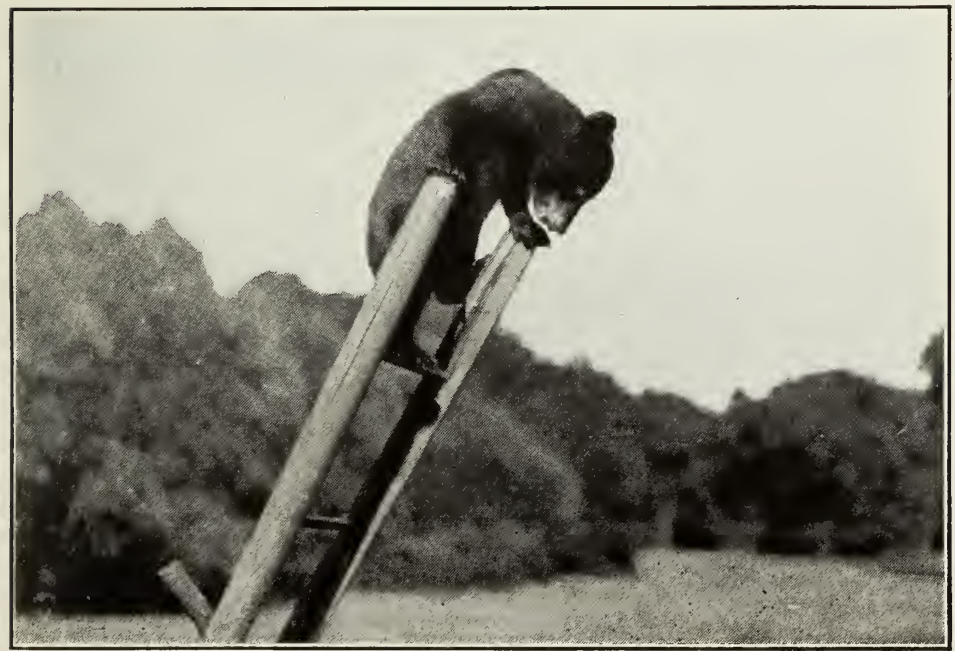

Finally to escape pursuit he dropped his booty and climbed a ladder 

Owing to his uncouth manner of feeding from his wooden trough, it was quite a task to keep him clean and presentable. Condensed milk is sticky, and if not removed at once accumulates all kinds of dirt. Though the cub was not opposed to a bath, for some reason he did n't care particularly to have me scrub the gluey remains of his meals from his face. Perhaps it was because a good deal of force had to be employed in order to complete his toilet. My method was simple, though rough. Grasping the youngster firmly by the back of his neck, I went rapidly over his dirty countenance with a big sponge. As Bruno grew larger, this act became more difficult and carried with it an element of danger.

One day, when I was in a hurry with his cleaning and was perhaps a little rough in my treatment, he bit my hand. I cuffed his ears quite soundly, and gave him a piece of my mind. In spite of this lesson, the next day he bit me again, without any occasion for it, and added a few scratches with his claws as if to show his authority. This time I chastised him with a switch. Next morning I was prepared for more trouble. I had ready at hand a good-sized stick, for I had made up my mind that the bear had to be taught that I was his master. I wanted to get a picture of the proceedings, should anything happen that might be of interest. 
My cousin kindly offered to take a hand in the affair. In order that the accumulation of food on the bear's face might be seen plainly in the photograph, I had put some dry flour into his breakfast. This touch of dingy whiteness gave him such a ludicrous aspect that I laughed in spite of myself, though I knew full well that it would add to the difficult task ahead of us.

Bruno had eaten his breakfast in the box-stall out in the cow-barn. Having finished his repast, without any further preliminaries he took up his position in one corner of the stall, where he could be safe from any attack in the rear. He seemed to know that there was trouble brewing, and the expression on his face conveyed the idea that he was ready and eager for it. I suggested to my cousin that he take the sponge, advance toward the corner, and make as if he were going to wash the bear's face. I would stand by with the camera, and if anything unusual happened, I would take a picture of it.

As we were planning the attack, Bruno stood up on his hind-legs, put his back against the wall, and thrust his paws out in front of him like a prizefighter awaiting the call for action. But my cousin was n't particularly anxious to begin. "I may not know much about photography," he said, "but I must confess that I have no knowledge whatever 
on the subject of bears. I'll take the camera and do the best I can, and you take the sponge and do the washing."

I finally persuaded him to make a bluff at it anyway, and promised not to let the bear do him any damage while he was making the attempt. With considerable apprehension depicted on his face, he slowly and cautiously advanced until the sponge was only two feet from Bruno's head and just beyond reach of the cub's paws, which were held alert, ready for immediate action. Here for a moment he paused, while the bear, looking him squarely in the eye, held his ground. "Come on, if you dare," his attitude plainly implied.

Cousin moved a step forward, and nothing happened; another step, and still no trouble. Then came the surprise. The sponge was lowered slowly until it touched the cub's head. Still Bruno made no fuss, but standing quietly in the corner, with the utmost composure allowed himself to be washed without a murmur of complaint. I never quite knew whether it was the punishment of the day before, or the big stick that he saw in my hand, that changed his attitude. At any rate $I$ never had any further trouble about washing his face. As a matter of fact, within a few days he graduated from the wooden trough and ate his meals without any fuss from whatever dish we set before him. 
Owing to his unusual bringing up, Bruno had never become acquainted with the ordinary animals of the woods and fields, and so I was curious to see what he would do when he met any of them. Down in the garden one day I found a large fat toad, and when Bruno was at lunch I placed the warty creature on the ground beside the saucer from which the cub was taking his food. Being quite hungry, at first he paid no attention to the intruder; but presently, as the saucer became empty, he caught sight of his curious visitor. With a jerk he raised his head, and for a moment, without moving a muscle, gazed in astonishment and with some misgiving at the strange monstrosity in front of him. His natural curiosity, however, soon overcame his doubtful frame of mind; he was a born investigator and this thing must be looked into. Very cautiously he reached forward his paw and ever so gently he touched the curious thing on the back.

The toad did as toads usually do when tickled from behind. It hopped, and with such force that it went quite over the saucer. Simultaneously the bear stood erect. He had a puzzled look of amazement and dismay on his hairy visage; he appeared to be utterly overcome with astonishment. It did n' $t$ seem reasonable that an insignificant misshapen creature like that could, with no apparent 


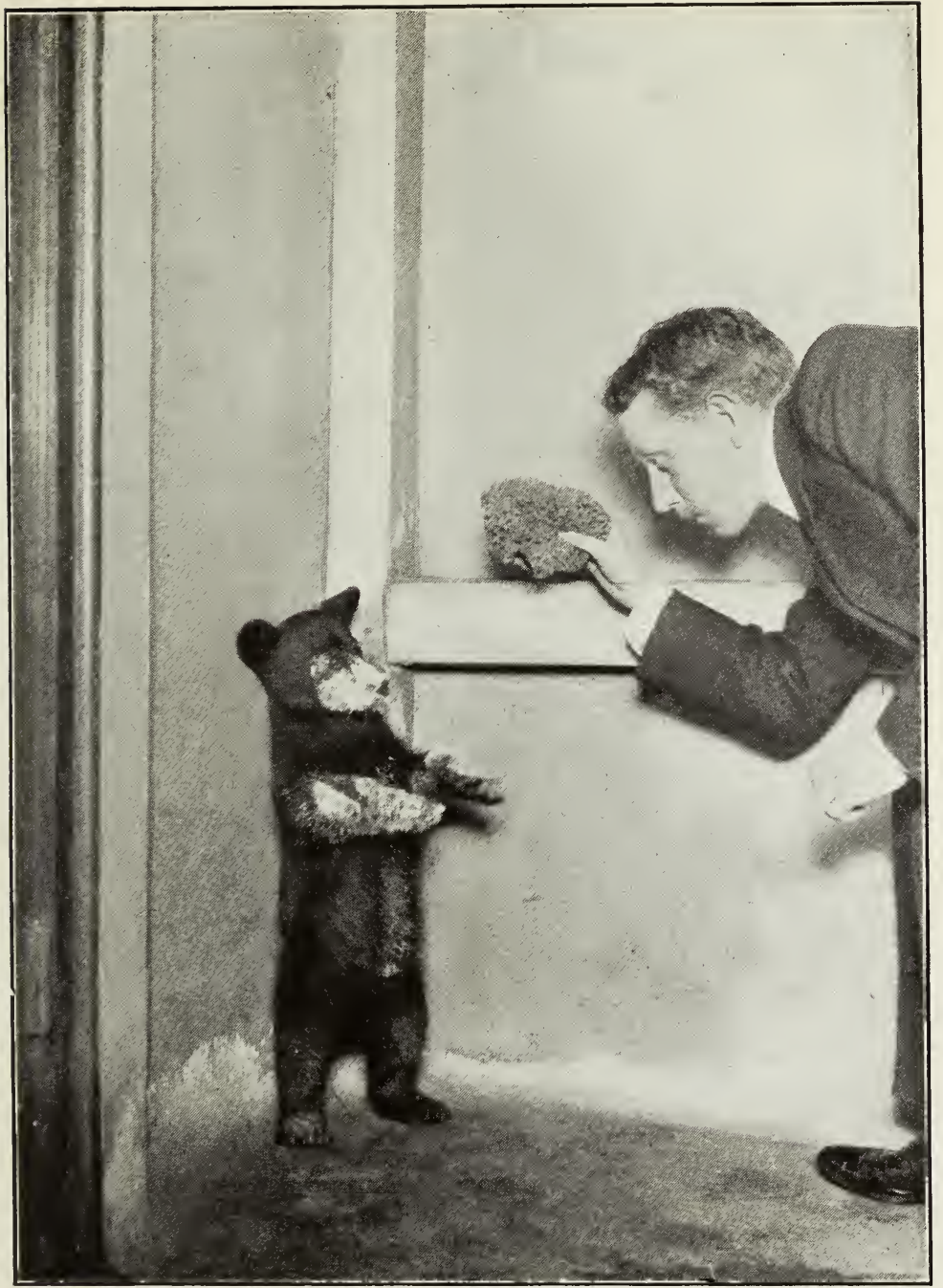

"Come on if you dare," his attitude plainly implied 

effort, cover so much ground in one leap. Bruno's paws hung inertly in front of him and his tongue lolled stupidly from his mouth. His breath came in short explosive gasps.

Suddenly the toad hopped again, and with a "Whoof, whoof, whoof," away ran the bear round the corner and out of sight. No more toads for him; one was enough for a lifetime!

Bruno apparently had a similar horror of frogs (rather strangely too, for wild bears eat frogs) whenever they jumped unexpectedly from the grass as he played about the pond. If one leaped in sight, he whined and snorted with terror, and waved his paws in the air as if to ward off the evil thing. Even a mouse that I liberated from a trap drove him to distraction. The tiny creature chanced to run in his direction, but it did not reach him, for Bruno was off and away at breakneck speed, and the mouse was left far behind.

The cub was growing rapidly now. On November 8, he weighed forty-three pounds. Once a week I got out the scales and had him stand on the platform to have his weight recorded. He was also gaining in strength, and although his outbursts of temper were less frequent as he grew older, they were more violent when they did occur. As with a spoiled child, everything was lovely as long as he could do as he wished. I was fre- 
quently asked, "How long are you going to keep that bear?" And my answer usually was, "As long as he will keep me."

It was a mooted question in the town, which would go first, Underwood or the bear; but I did not want to lose my cub, for of all the long list of animal pets that $I$ had owned Bruno was easily the best and most interesting. Winter was close at hand, and with the cold weather the bear would probably be asleep most of the time. Under these circumstances no harm could come to anyone, and I made up my mind to keep him at least until the following spring.

The advent of a new calf in our cow-barn made it necessary that Bruno should take up other quarters, for the mother cow was now seriously opposed to his presence. Out in front of the house was a fair-sized cage, which in former days had been occupied by my various other animal friends. Just outside, a few feet from the end of the cage, I dug a deep hole in the ground, and in it I placed a large dry-goods box, then covered it with earth. I connected the box with the cage by an underground passage, using two empty flour-barrels to form a tunnel. Bruno's home was now ready for occupancy, and presently he moved in. He found no fault with his new quarters, except when he was left alone; then he was uneasy and fretted and 


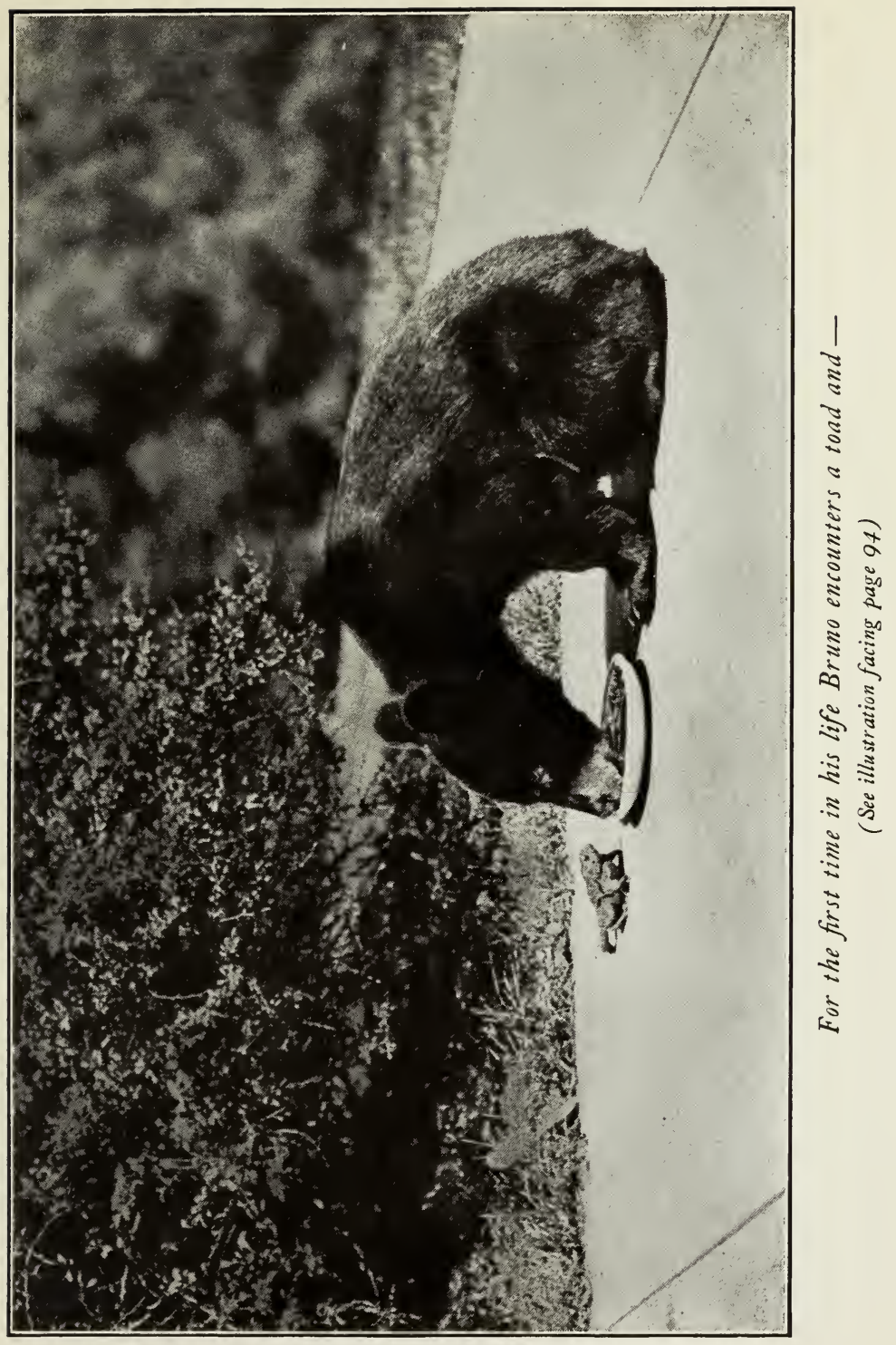





\section{BRUNO IN BELMONT}

howled dismally. So long as there was anyone in sight, he made no fuss.

Some of my brothers' dogs were of ten playing about, and now that the bear was caged, he wanted to make friends with them. This suggested to me the idea that a dog might be a good companion to cheer him up a bit when we were away. But no one would lend me a dog for the experiment. Just at this time, as good luck would have it, however, I had a chance to buy a dog at a cut-rate price. I was crossing Boston Common one morning when I was accosted by a dirty, unshaven individual leading a disreputable-looking dog by a string.

"I say, mister," he muttered, "could yer give a feller the loan of a quarter?" Then he added, as he saw a doubtful expression come over my face, "I'll pay you back when I sell this dog."

Here was my chance. "What do you ask for the dog, and what kind of dog is it?"

"She 's a good dog; I'm hard-up and I'll sell her for fifty cents; I call her a beagle," said the man.

"You might also call her a spaniel," I volunteered, "but she looks to me more like a fox-terrier."

"Well, maybe she is," the dog man assented. "The feller that give her to me called her Foxy. Maybe that's why he give her that name."

Fox-terrier, dachshund, or spaniel, it made no difference to me. She was a live dog. Where again 
would I ever be able to get so much dog for so little money? The transaction was immediately concluded, and I stepped briskly off with my prize in tow. Arrived at home, I gave her a hearty dinner.

It did my soul good to see her eat. It did her good also. Her whole appearance changed; she had some style now. She pricked up her ears, lifted her tail from between her legs, and wagged it rapidly to and fro. Then I gave her a bath, and when she was clean, she looked the lady that she really was. She was black and white on back and sides, with spots of tan on cheeks and ears and both forelegs - a very respectable-appearing foxterrier.

For a day or two Bruno, when out of his cage, would have nothing to do with the dog. Every time Foxy came near him, he ran to Comrade for protection. Foxy had no fear whatever of the bear; in fact, the day after her arrival she drove him away from his dinner and ate it herself. Little by little Bruno overcame his fear, and by the end of the week they were firm friends. Foxy was glad to spend a few hours each day in the cage with her new companion, and when not in the cage she was usually within sight. It was a fine arrangement, and from now on Bruno was a happy and contented bear. 


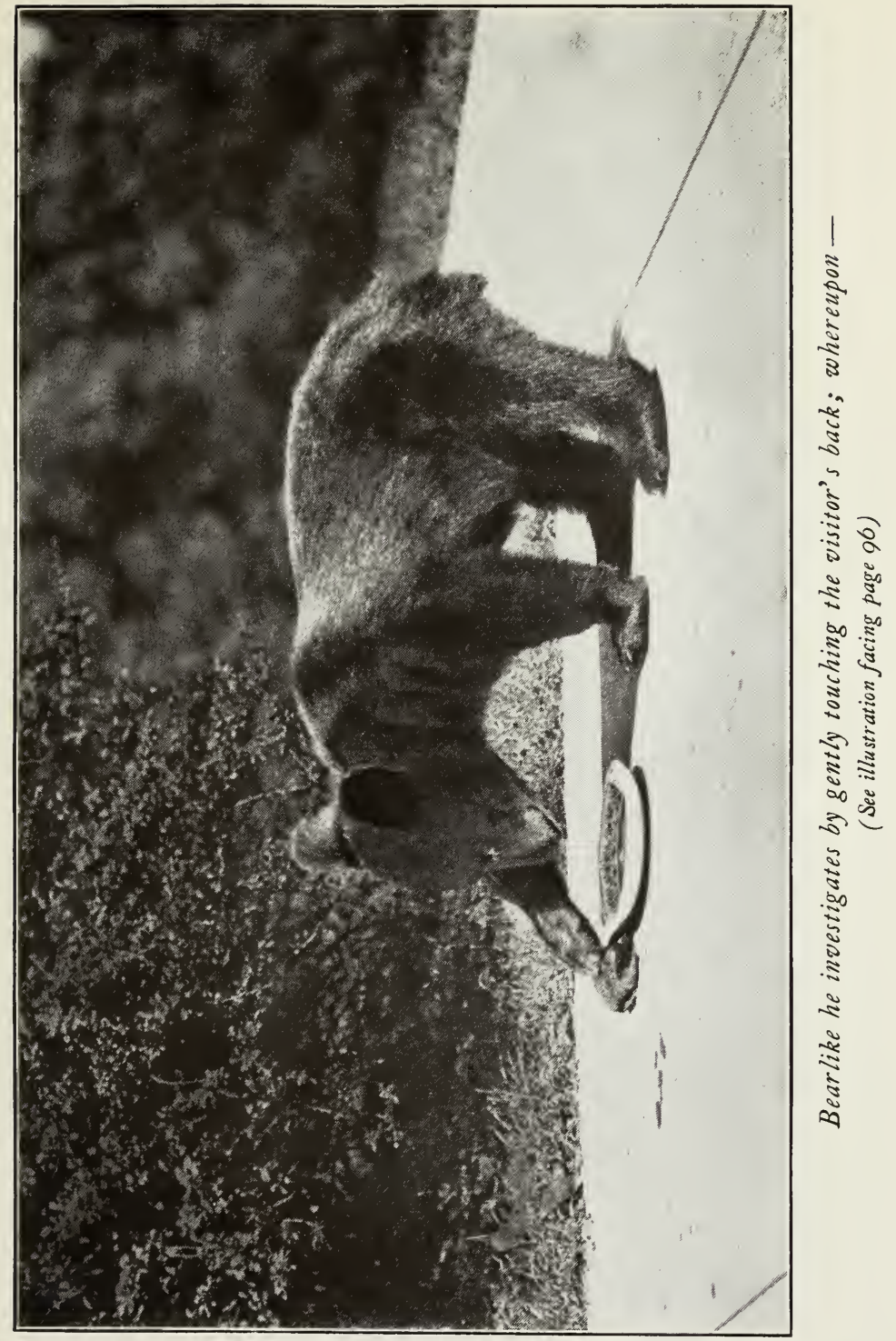





\section{BRUNO IN BELMONT}

The fame of my pet had gone abroad, and many people came to see him. By this time I had made my photographs into lantern-slides and had told the story on several occasions, illustrating it with the stereopticon. I was bothered by frequent requests from newspapers and magazines that wanted the story for publication; and about this time a letter came from Mrs. Weldon, saying that a newspaper man had been to see her.

"He was crazy to get those pictures and have me tell the story," she wrote; "but I would n't tell him a thing, and I would n't let him see the pictures. He was real mad about it."

One day, when we were out of town, a reporter appeared at my home. He told the housekeeper that he wanted to photograph the bear, and though he was refused permission, he insisted that this cub was in a way public property and, as his paper had ordered him to make a story, he would have to do as he had been told. So, in spite of all that could be done, he had his own way; and next day there appeared in one of the Boston papers an article which contained many misstatements and was illustrated by a picture that looked more like a St. Bernard dog than it did like a bear.

It was but natural that my story of Bruno's unique bringing-up should attract unusual attention. No one had ever heard of a woman doing a 
thing of this kind before. While it is probably true that no other bear's life had ever been saved in the same way for a similar reason, I was soon to learn of an extraordinary custom that has to do with the feeding of bears' cubs in an analogous way. This curious practice is indulged in by the Ainus, those quaint and primitive people of Aryan stock who were the original inhabitants of the Japanese islands, and who now, in dwindling numbers, live on the island of Yezo. It is an ancient belief of the Ainus that they are descended from the bear, the animal that plays the most prominent part in certain of their religious ceremonies.

Bears' cubs are highly prized and much sought by these simple people. The Ainu hunters are willing to risk their lives in order to secure a live cub. When captured, the little creatures are handed over to certain women who have been specially chosen to nurse and bring them up. These cubs, as was the case with Bruno, often become members of the family and play with the children; but their treatment does not come from any love of the animal or from any wish to preserve its life. Quite the contrary, in fact. At a certain age, its life is sacrificed, and with much rejoicing, at the time of a great feast, the flesh is eaten.

I became aware of these customs in a curious and singular way. In the fall of 1904 I attended the 


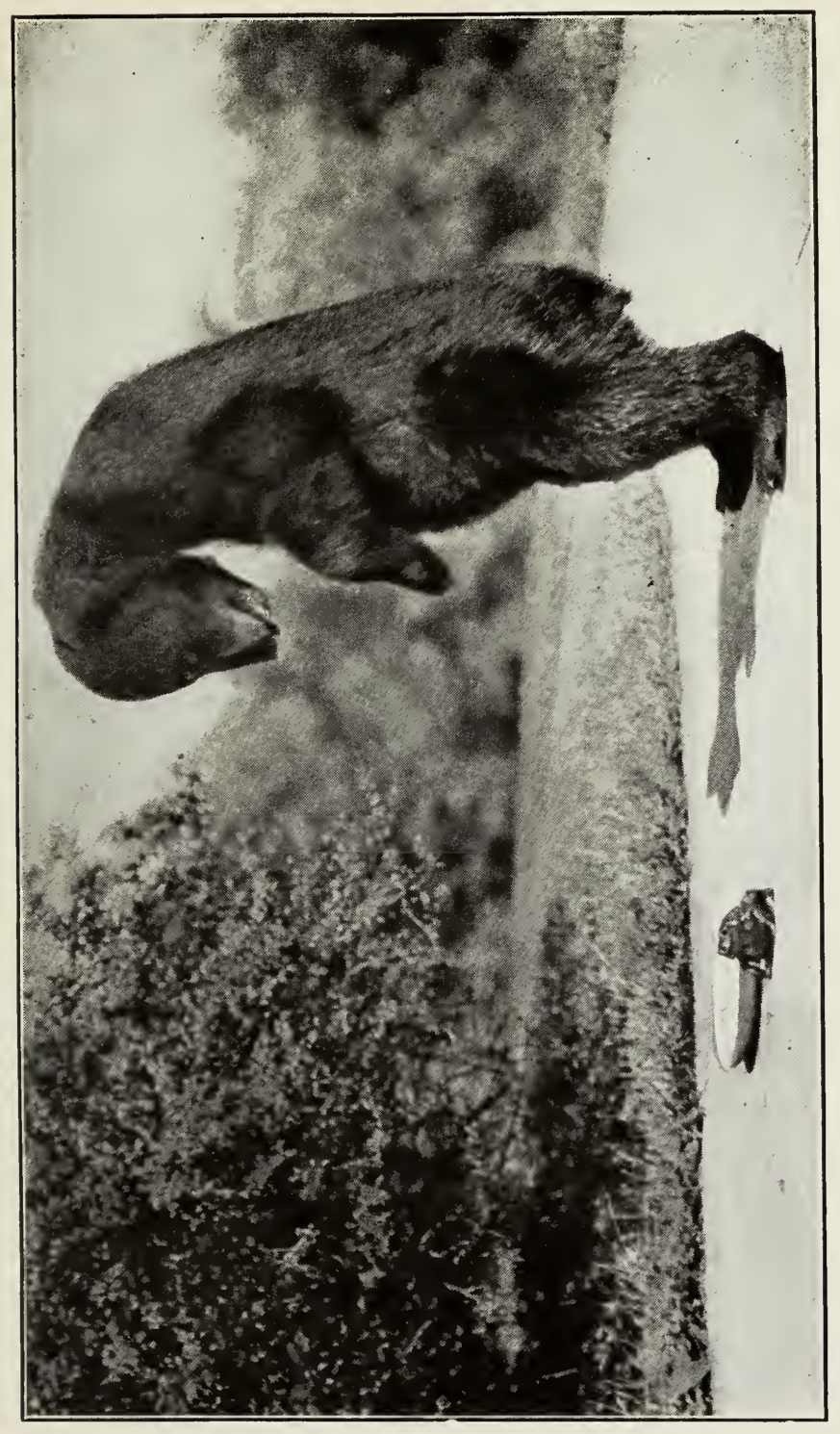

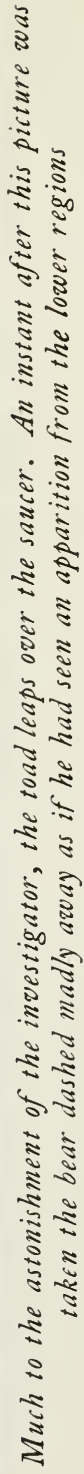





\section{BRUNO IN BELMONT}

World's Fair at St. Louis. While visiting the anthropological exhibition, where were gathered together people from all sections of the globe, I came to the village of the Ainus, and knowing a little of their history, I was much interested in them.

I soon became acquainted with the man who had these people in charge, and learned from him more of their unusual customs and beliefs. I had brought with me to St. Louis some of my bear photographs, and next day I again visited the Ainu village and took my pictures with me. The simple people were called together in one of their larger buildings, and through an interpreter I told them the story of my bear. They listened with the utmost attention and respect, and plainly but quietly expressed great interest and amazement.

Afterward, when I passed around the pictures, my audience became violently excited. They jabbered and gesticulated one to another, pointed to the pictures and then to me. Some of them stepped forward and gave me what I took to be a form of salutation. The men went through a series of dignified motions with their hands, slowly rubbing them together, then waving them about, and concluded this exercise by stroking their beards. The women's method of expressing approval was more simple. They placed their right hand held open 
over the mouth and drew it several times from left to right across the lips.

At the time of my exhibition the Ainus chanced to have with them as transient visitors a stoical western North American Indian and his squaw. They were clad in all the finery of their tribe. It was interesting to observe the contrast in the behavior and actions of these distinctly different races of aboriginal peoples. The Indians sat in dignified silence a little at one side, on the floor. They expressed no particular interest in the proceedings. Not until they saw the photographs, did a gleam of animation show on their inert countenances. They leaned a little forward now, and exchanged a few low spoken words together, as they gazed at the pictures. "Good," grunted the noble red man a moment later, as, with a solemn face and a slight inclination of his head, he handed the collection back to me.

Bruno and the fox-terrier had now become boon companions, and whenever the bear was given his liberty, they romped together by the hour. Football was a favorite sport with them. Out on the lawn they chased the ball about and executed some wonderful plays. To make it possible for them to carry the ball, it was never fully blown up and the lacings, which were extra long and heavy, hung in 
loops and were not drawn tightly together.

There were no particular rules about their game; it was every man for himself, each striving to keep the ball as long as possible from his opponent. Foxy's place on the team was at tackle, and in this position she was a star player. Her method was unique. Bruno, after a heavy plunge through centre for a ten-yard gain, would be off for a long run down an open field, with no one between him and the last white line, for a touchdown.

Foxy was too light in weight to stop the big fullback by any ordinary method of play; but what she lacked in weight she more than made up in speed and head-work. Her opponent once having passed her, she was in a position to execute that particular play for which she had become so justly famous. Three rapid jumps brought her within striking distance of her flying adversary; one jump more and the tackle was made, and the fullback was downed in his tracks.

We never quite understood how Foxy knew of the one weak spot in Bruno's make-up, though the knowledge of it may have been acquired by accident. As she overtook her opponent from the rear she naturally tackled that part of his anatomy that came first to hand. It was n't a case of taking the bull by the horns - it was taking the bear by the tail. The surprise and the force of the sudden re- 
straint so completely upset the bear's calculations that he lost his head, dropped the ball, and mad with rage and chagrin, began to bite his paw. Foxy immediately pounced upon the oval, and rolled it out of reach.

Sometimes the dog was caught with the ball. Hidden now from sight beneath the black fur of the bear, she kicked and squirmed and tried to get away, but strong arms held her fast until she lost her temper and began to bite; then she was released.

Strangely enough, in all their rough-and-tumble play the bear never tried to hurt the dog. Foxy might pull his tail or bite his ear, but he never punished her for it. He might make it interesting for someone else, however, if someone happened to be in the immediate vicinity. One day Foxy wanted a share of the bear's dinner, and several times Bruno mildly pushed her aside when she tried to get it. Suddenly, in exasperation, she took him by the ear, and jerking and tugging upon it, tried to pull him away. In a towering rage he shook himself clear, and making a straight dash for me, caught me by the slack of my lower garment and held on until the cloth gave way.

Early in December, as the days grew colder, Bruno began to spend more of his time in his den; on a chilly morning he seldom made his appearance 


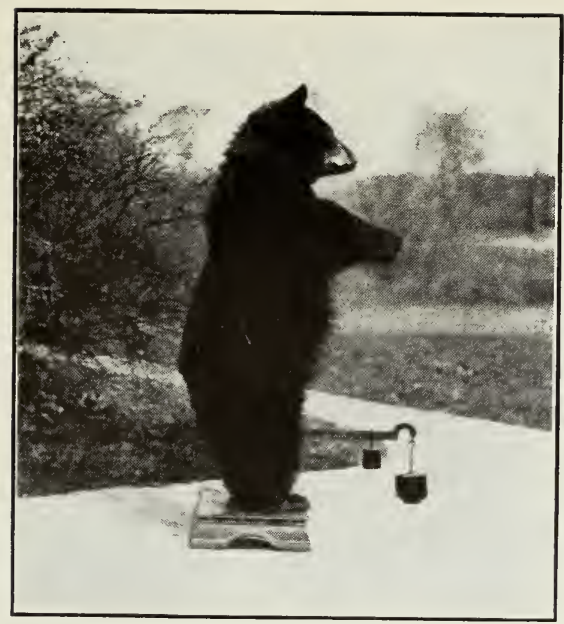

Once a week his weight was recorded

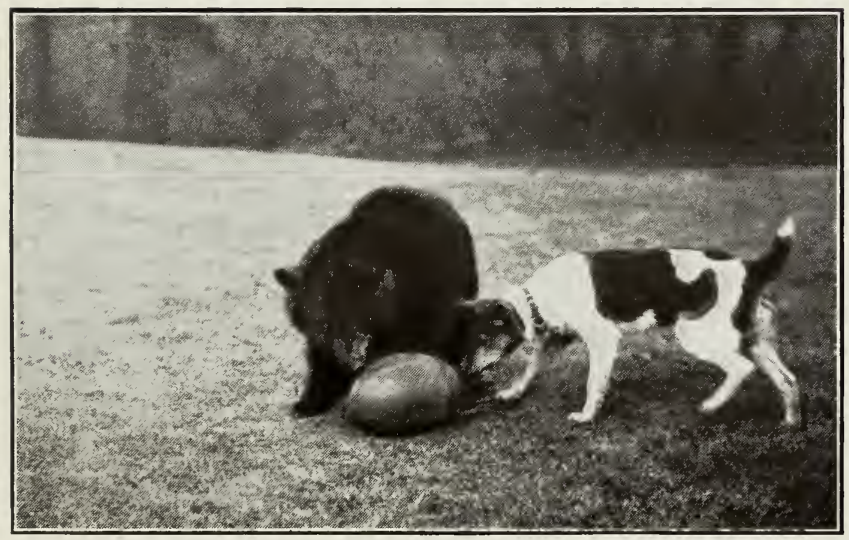

Football was a favorite sport with these friends 

before eleven o'clock. Several wheelbarrow loads of dry leaves, which were put into his cage, he promptly took beneath the ground for bedding. The entrance to his subway he always kept closed, using part of his leaves for this purpose.

My bear never really denned up, or hibernated, as is the custom of wild bears at this season. Only when it was very cold for several days, with the thermometer standing well below the freezingpoint, did he stay down below for any length of time. These periods of hibernation seldom extended more than a week. During these times of seclusion it seemed impossible, however, to awaken the bear, even though I called loudly to him with my mouth close to the entrance of his retreat, and rattled a spoon against his feeding-dish, making an alluring sound that formerly had brought him out quickly enough.

On a cold day, when Bruno lay in a stupor in his bedroom down below, a naturalist who was a friend of mine came to see him. He had made a long journey for this purpose, and I was loath to disappoint him, but there seemed to be no way to get the bear in sight. Though I called and shouted, there was no response.

It was Foxy who solved the problem and saved the day for me. She had entered the cage and stood wagging her tail, with her head in the tunnel, 
while I was calling. Suddenly she dove into the leaves and disappeared in the subway. Soon there came to us up through the passage the distant sound of an altercation. Foxy was scolding and Bruno whining and complaining.

The noise grew louder, and presently the dog's stubby tail appeared through the leaves. It was twitching in great excitement. Slowly by a series of spasmodic jerks her body came in view. Then Bruno's sleepy face appeared. One ear was lost to sight, for Foxy held it in her mouth. Tugging, straining, and scolding, she dragged him forth inch by inch, nor relinquished her grip till he stood clear of his threshold. Then she turned to me for recognition and praise, and having received it, left the cage. Bruno yawned and opened wide his cavernous mouth; he winked his blurry eyes and shook his drowsy head. Bits of dried leaves sticking to his face gave him a befuddled, carry-mehome expression that was ridiculous to behold. One almost expected to hear him ask: "What's the matter, boys? Where am I at? What's all this row about?"

For some time he sat stupidly gazing here and there; then slowly his wits came back to him. He got up on his feet and laboriously stretched first oneleg and then another, as if he were trying them out to see if he really would be able to walk about again. 


\section{BRUNO IN BELMONT}

During these coldest days the bear was not a particularly interesting pet, and I may as well let him sleep for a time, while I turn to some incidents which, though they concern Bruno only indirectly, are in many ways the most extraordinary part of his life-story. 


\section{CHAPTER VI}

\section{IN TIMES OF TROUBLE}

IT might naturally be supposed that Bruno, when he left the lowly log-cabin home of the Weldons in the forest, would have gone forever out of their lives, to be remembered only as a frolicsome pet about whom they would always have a fund of interesting stories to tell. Surely no one could have imagined that the act of saving from starvation this furry mite of helplessness could possibly play any far-reaching part in the destiny of the backwoods family. Who would have thought that this kindly deed would be the means of saving the life of the generous mother, and again and again bringing help to the family in times of sore distress and need? Yet this, indeed, is the simple truth.

The spark of life kept burning within the little creature that had been born beneath the cold winter snows kindled, as it were, a genial glow that has wrought many wonderful things for the Weldons. Even to-day, when I am writing this story, eighteen years after the first incident happened, it has not ceased to bring them cheer and comfort, with practical help, when in sickness or in trouble.

Late in the winter of 1904 I again visited my camp in Maine. I had previously heard that the 


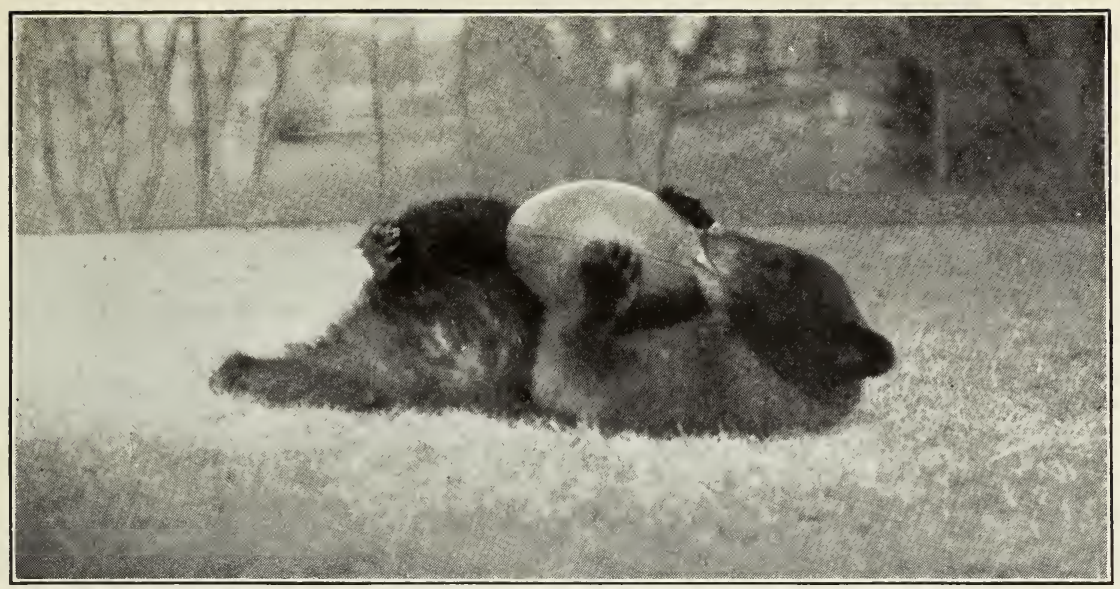

Bruno falls on the ball. First down, ten yards to gain

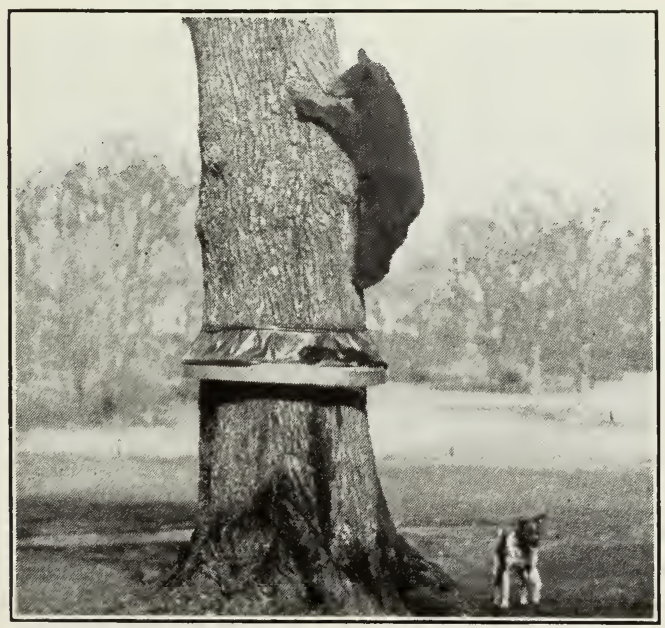

He could cling to a tree like a squirrel 

Weldon family was having difficulties. Mr. Weldon, some time before my acquaintance with him, had cut his foot quite badly with an axe. The wound had never healed in a proper manner, and in the fall of the year when I took the bear, he had the misfortune to have this same foot crushed beneath a heavy log. While this accident did not incapacitate him entirely, it made it very difficult for him to work with any degree of comfort. In fact, this infirmity prevented him from earning his usual wages.

At the railroad settlement we learned that the family had left the lumber-camp in the woods, and was now living in a small log-house close beside the road, about half-way in to the lakes. Our way took us past their door, and we stopped to call.

Mrs. Weldon and her three children were at home. Because of their straitened circumstances she had been obliged to give up the two adopted ones, and her oldest child - now a little girl of six years - was the housekeeper; for she herself lay ill upon the sofa. Mr. Weldon was away looking for work, but owing to the painful condition of his foot had been unable to do much for several months. The kind-hearted mother was weak, discouraged, and worn in mind and body. With the coming of spring there would be another mouth to feed, and the doctor had told her that, unless she could rest 


\section{6}

\section{WILD BROTHER}

and regain her health and strength, her prospect of living to see the summer was extremely uncertain.

In spite of these unfavorable predictions, she uttered never a word of complaint, nor did she ask, or in any way suggest, that we come to her assistance. However, we were able to send from our camp a number of things that added to the comfort of the Weldons.

Shortly after our return from Maine, I told the story of the bear before an audience of influential men in Boston. I illustrated it with stereopticon slides, and showed many of the pictures which appear in this book. The effect was both surprising and gratifying; for without the slightest intimation on my part that any material help for the family would be welcome, a substantial sum of money was contributed by the club members who were present. As a matter of fact, arrangements had already been made for the immediate relief of the Weldons.

The better to show the sincere and genuine qualities of these faithful people, I will bring into my story a number of letters which from time to time they have sent me and which will give mute though convincing evidence of the sterling, ingenuous character of the family. The first of these letters is dated February 28, 1904, and reads as follows:- 


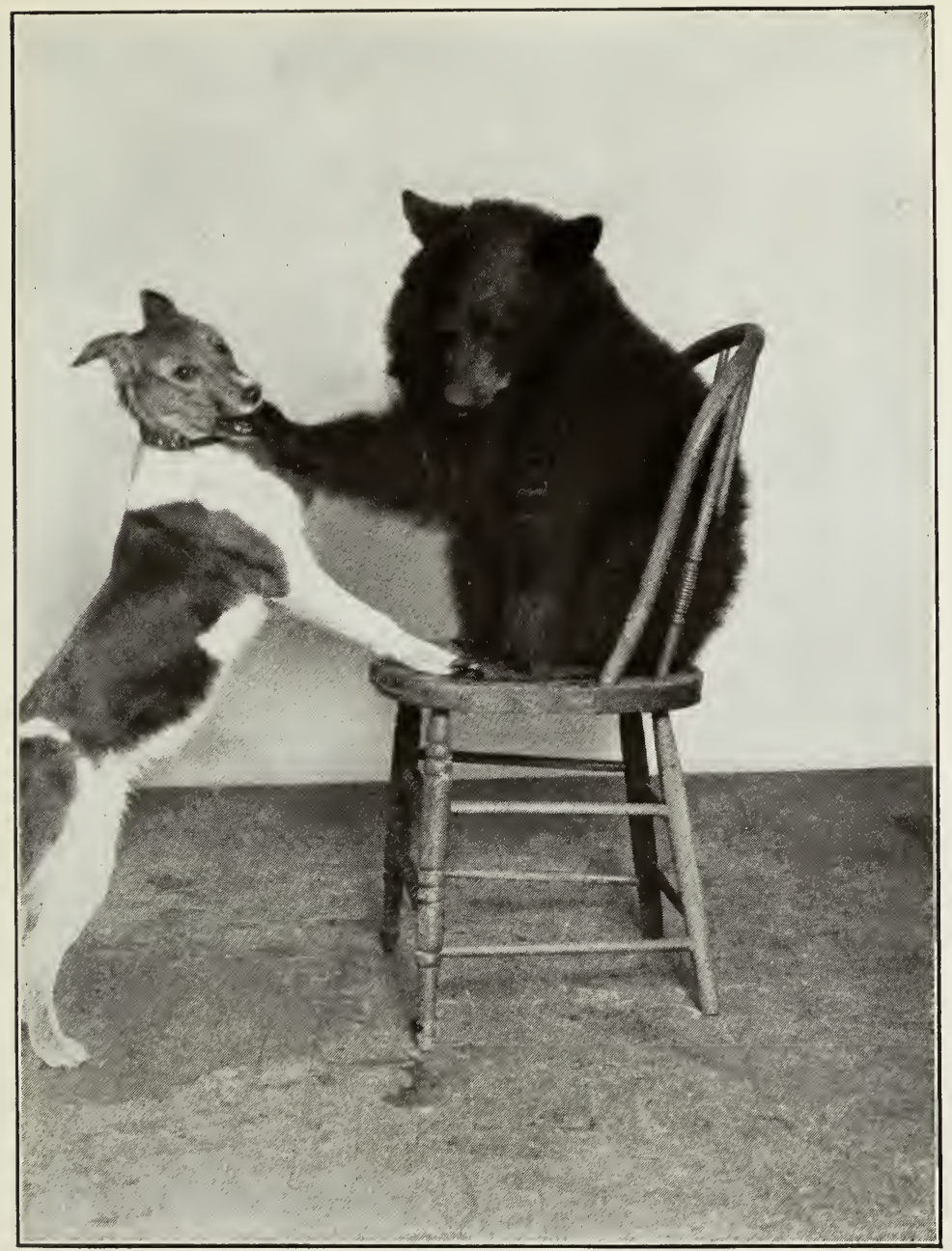

The bear always treated Foxy with the greatest gentleness, even when the dog bit his paws 

Kind Friends:-

It is indeed with heartfelt gratitude that we write our thanks for your kindness to us, for the food and clothing and the money to pay the doctor, who gave the help that Mrs. Weldon stood so much in need of. She is not yet able to be around the house but a very little, but she is much better, and as the warmer weather approaches, the doctor thinks she will get well.

The box from Boston arrived safely and another one from Springfield, also the check. This we gave to the doctor and much help we have gained through him and the medicine which he furnished us. Again we wish to thank you for your kindness and any way we can serve you please let us know and we will be only too glad to do it.

Gratefully yours,

G. M. and Mrs. K. W. Weldon.

\section{In April came this letter :-}

Dear Mrs. Underwood:-

I received the box you sent me all safely, and I thank you very much for the things that came in it. I am stronger and Mr. Weldon feels better than he has for months. I think with you that I had lost my courage to live my life as I had found it. But thanks to your kind interest in me and my 
family and the help that has been given us, I shall have my health and strength back again when summer comes.

\section{Gratefully, \\ K. W. WELDON.}

On May 5 there came these welcome tidings from Mr. Weldon :

DEAR SIR:-

It is with pleasure that I write to let you know that Mrs. Weldon is on the road to recovery. We have another daughter. She came with the swallows on May 2d. The baby and Mrs. Weldon are doing well and I am happy. Thanking you for your kindness we both remain truly yours,

G. M. WELDon.

I was now receiving a good many requests for the bear lecture, which I was giving under the title "A Strange Story of the North Woods." As I continued to relate these unusual happenings, I was constantly receiving additional proof that there was something in them that made a strong appeal to the hearts of the men and women who heard the story. Sums of money were voluntarily sent me, with the request that I use them for Mrs. Weldon. 


\section{IN TIMES OF TROUBLE}

This spirit was vividly manifested at a dinner given by the Camp-Fire Club of America one evening, at the Hotel Astor in New York. This club is an organization of gentlemen who are interested in the better protection of birds, fish, and animals, and in the preservation of the forests.

More than three hundred members and their guests were present on the occasion when I had been invited to tell them the story of the bear. The audience was attentive and sympathetic, and at the conclusion of my narrative a gentleman rose and, addressing the president of the club, said :

"Mr. President, if it is agreeable to the members of this club, I move that someone be appointed to pass the hat around these tables and take a collection for that good woman."

Immediately I rose and, requesting that this motion should not prevail, explained that already a sum of money had been set aside for Mrs. Weldon's benefit, and that I anticipated having no trouble in getting more if it were needed. Of course I appreciated their generous thought, but I should be better pleased if nothing were done about it at that time. I had no sooner finished speaking than another member of the club rose and, catching the president's eye, said : -

"Mr. President, one of the objects for which this 
club exists is the protection and propagation of wild life. I think that none of our members here present have ever heard of a more noble example of animal protection than has been carried out by this kind-hearted woman. I should like to offer an amendment to the previous motion. I move, sir, that the chair appoint two men to pass with hats around these tables."

Amidst great applause this motion was unanimously carried, and a moment later two black derby hats were passing from hand to hand round the hall. Presently these were returned to me full and overflowing with green bank-notes.

At midnight, when I walked down town to my hotel, two men accompanied me, as body-guards, for I was a traveling savings-bank, with all my pockets filled with cash.

"How did the evening go?" asked Mrs. Underwood on my return.

"Oh, pretty well," I replied, as, emptying my pockets, I hid the white bedspread beneath a shower of paper money.

"Oh, you have n't robbed a bank ?" she gasped.

"Quite the opposite," I assured her, "This money is going into a bank. It's a gift from a group of red-blooded men who wish to honor and help a woman whom they believe to be worthy of great respect. You can guess who she is." 


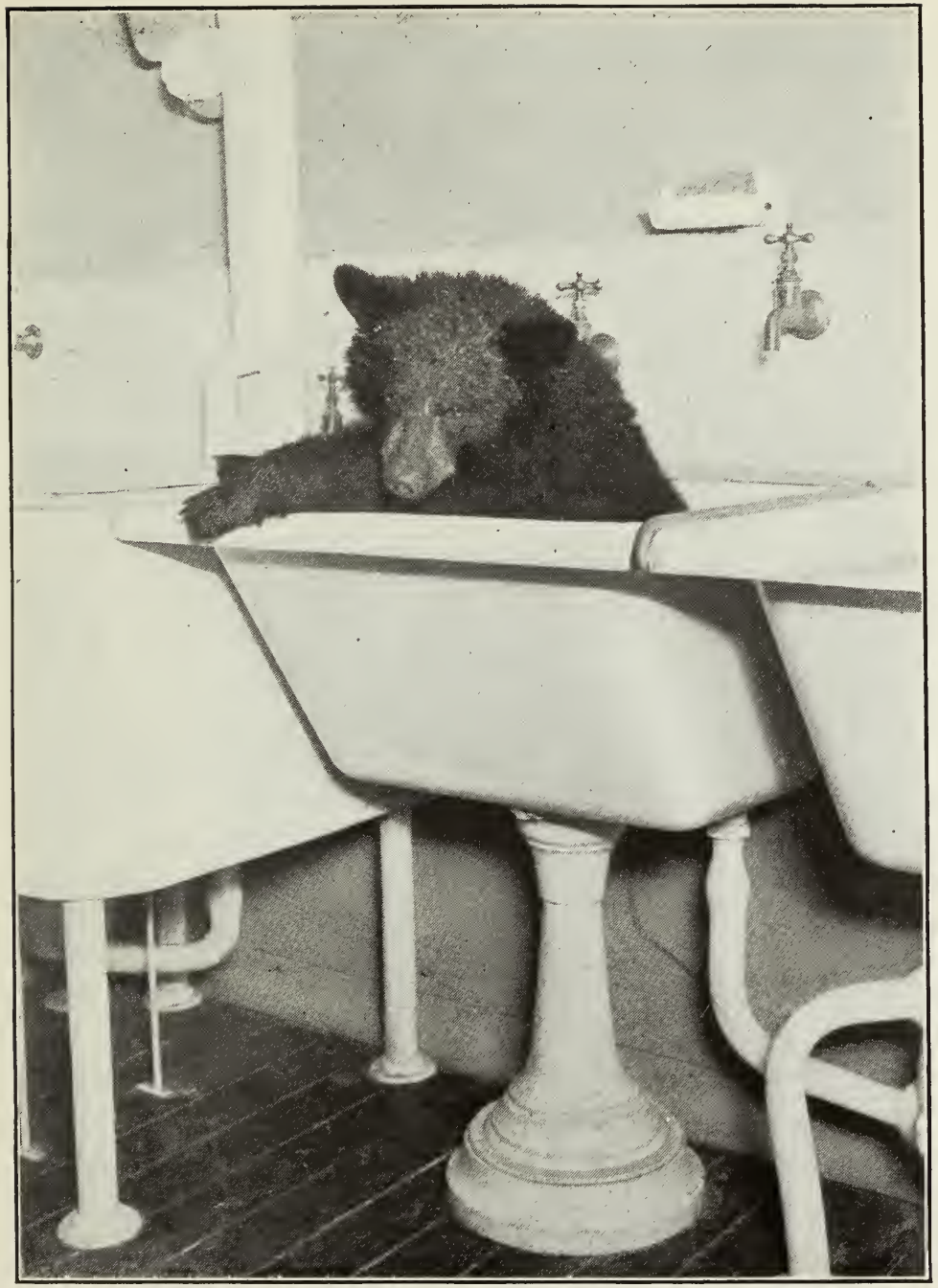

There he sat in the warm water with the soft clothes of the week's wash comfortably settled beneath him 

While these events were going on, Bruno, whose early life was exciting so much interest, was spending most of the wintry days in his snug leaf-filled den in Belmont. At times, when the weather was warmer, he came to the surface of his own accord, but he did not care much about leaving his cage, and seemed lazy and sluggish.

To overcome the difficulty of getting him out, I used figs or raisins as a lure. Holding these delicacies, of which he was very fond, tantalizingly just beyond the end of his nose, I gradually coaxed him forth, so that the cage-door could be closed behind him.

When once he was outside, it did n't take Foxy long to get him limbered up. About an hour of exercise, however, was all he cared for; then of his own accord he returned to his home, opened the door, and walked in.

Not far from where the bear's cage stood is a small one-story building, which plays an important part in the household economy of our family. This is generally known as the laundry, and the largest of its three rooms is the drying-room. But by me this room is dedicated to a use that far transcends the mere drying of the week's wash.

It is a room of generous proportions, lighted overhead by a large skylight. I like to call this my studio, for here occasionally I try to entice a 
friend or some animal to pose in front of my camera. In to this room, during the winter, I often invited Bruno and the dog.

The bear never accepted these invitations with any great show of pleasure. In fact, as I have already described, it was only by subtle strategy and much persuasion that he could be induced to leave the comforts of his own snug abode. When the earth was white with snow, he refused absolutely to take one step beyond the threshold until a path was dug and the cold snow completely removed.

Once within my studio, however, he enjoyed the gentle heat of the place, with the warm sun shining down upon him through the glass roof overhead. Back and forth, round and round, he galloped, with Foxy chasing after him, his long claws clicking noisily on the hardwood floor. Growing tired of this sport, he jumped into a chair to be away from the dog, where he could have a rest. But Foxy, wanting the game to continue, bit his paw and tried to start him off again.

One day, while I was in the studio striving to get some photographs of the bear, there came an announcement from the house that dinner was served. Not having time to take the bear back into his cage, I closed the two sliding doors that separate my room from the laundry, and left Bruno to look after himself until my return. 


\section{IN TIMES OF TROUBLE}

A few minutes later, it occurred to me that I was taking a risk in leaving my camera unguarded in the room with the bear; so I asked my boy to run to the studio and let Bruno out, or bring the camera in.

Presently I heard a shout: "Father, come quick, and see what Bruno's doing."

I rushed back to salvage what might be left of the camera, for I feared the worst. My anxiety was groundless, however, for though the bear was in mischief, the camera was safe. In the few minutes of my absence Bruno had rolled open the two heavy sliding doors and was now in the wash-room. There he sat in perfect contentment, in one of the laundry tubs, soaking in the warm water, with the soft clothing of the week's wash comfortably settled beneath him. It was a cold February day, and the look of pleasure on his roguish face showed how much he was enjoying this midwinter luxury. With great composure, he sat perfectly still while I took his picture.

Then, before I could slip in another plate-holder for a second shot, he turned about and reaching up to the soap-tray on the wall over the tub, took from it a bar of yellow soap and began to wash his hands. I did want to get that picture; but by the time a new plate was in position, Bruno had dropped the soap into the tub. Of course, he was 


\section{WILD BROTHER}

not actually using the soap to clean his paws he was merely investigating, and out of curiosity turning the soap over and over to get a good look at it.

Bruno came through his first winter successfully. The cold season had a good effect upon him; he was much more tractable and seldom lost his temper. 


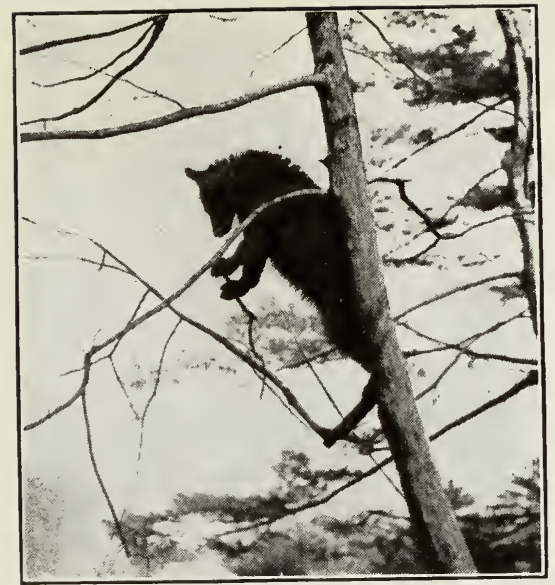

A sport that he enjoyed was to climb out on the small limbs

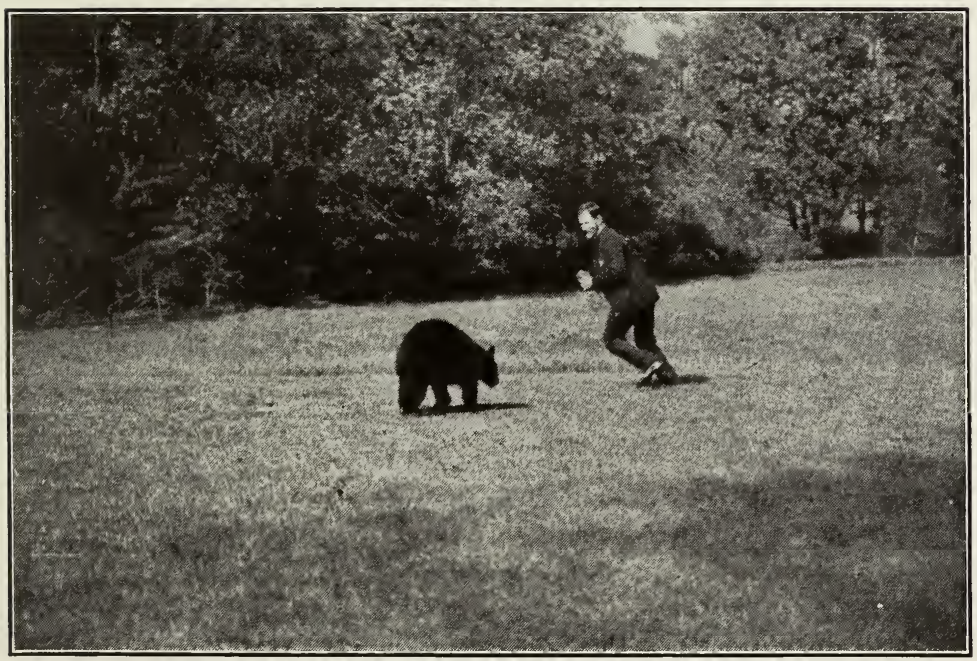

$A$ hard tomato thrown accurately excited Bruno's wrath, - and he chased his assailant down into the meadow 



\section{CHAPTER VII \\ BRUNO MUST DEPART}

IN the spring, when Bruno was a little more than a year old, I taught him a few simple tricks. He learned very quickly. At my command he would roll over, sit up, lie down, or stand on his hindlegs. I taught him these accomplishments through a series of rewards. When he obeyed an order, I gave him a fig. It was astonishing to see how soon he came to understand what I wanted. In fifteen minutes I taught him to roll over. At the command I turned him over with my hand, then gave him the fig. After a few demonstrations of this kind, he rolled over without my touching him.

As Bruno grew older, he became less particular about the manner in which his food was served. He was very gentle now when I fed him from my hand, and never grabbed for anything. I could even hold a grape or a raisin lightly between my lips and, with perfect safety, allow him to take it from me.

Bruno was in fine condition that spring. $\mathrm{He}$ developed a fondness for climbing, and could cling to a tree-trunk like a squirrel. No trees were too large for his ascent. He liked to climb out on the smaller limbs and swing and teeter up and down 
on them. After enjoying this sport, he would lower himself by his paws from one limb to another, like a monkey, and drop to the ground.

In July, when eighteen months old, he weighed eighty-five pounds and, standing on his hind-legs, measured four feet, six inches. We could almost see him grow - and his appetite was growing too. As summer came on, he began to develop a liking for fruit and vegetables. Bananas were in special favor; one day he ate six of them and then whined for more. Carrots, turnips, and parsnips also were considered as delicacies by him. Though it was against the rules, he liked to get into the garden and dig them for himself.

One morning we found Bruno in the middle of the tomato patch, thoroughly enjoying a feast of the red ripe fruit. A friend who was visiting me volunteered to drive the marauder away from his plunder, but the bear was stubborn and defiantly stood his ground. Suddenly a well-aimed hard green tomato landed with a thud on the side of his head. The effect of this successful shot was startling - the robber left his booty and, making a rapid advance upon his assailant, drove him out of the garden and pursued him down into the meadow. Here, the day being warm and his temper having abated, Bruno gave up the chase. Then, with Foxy's help, I escorted him back to his cage. 


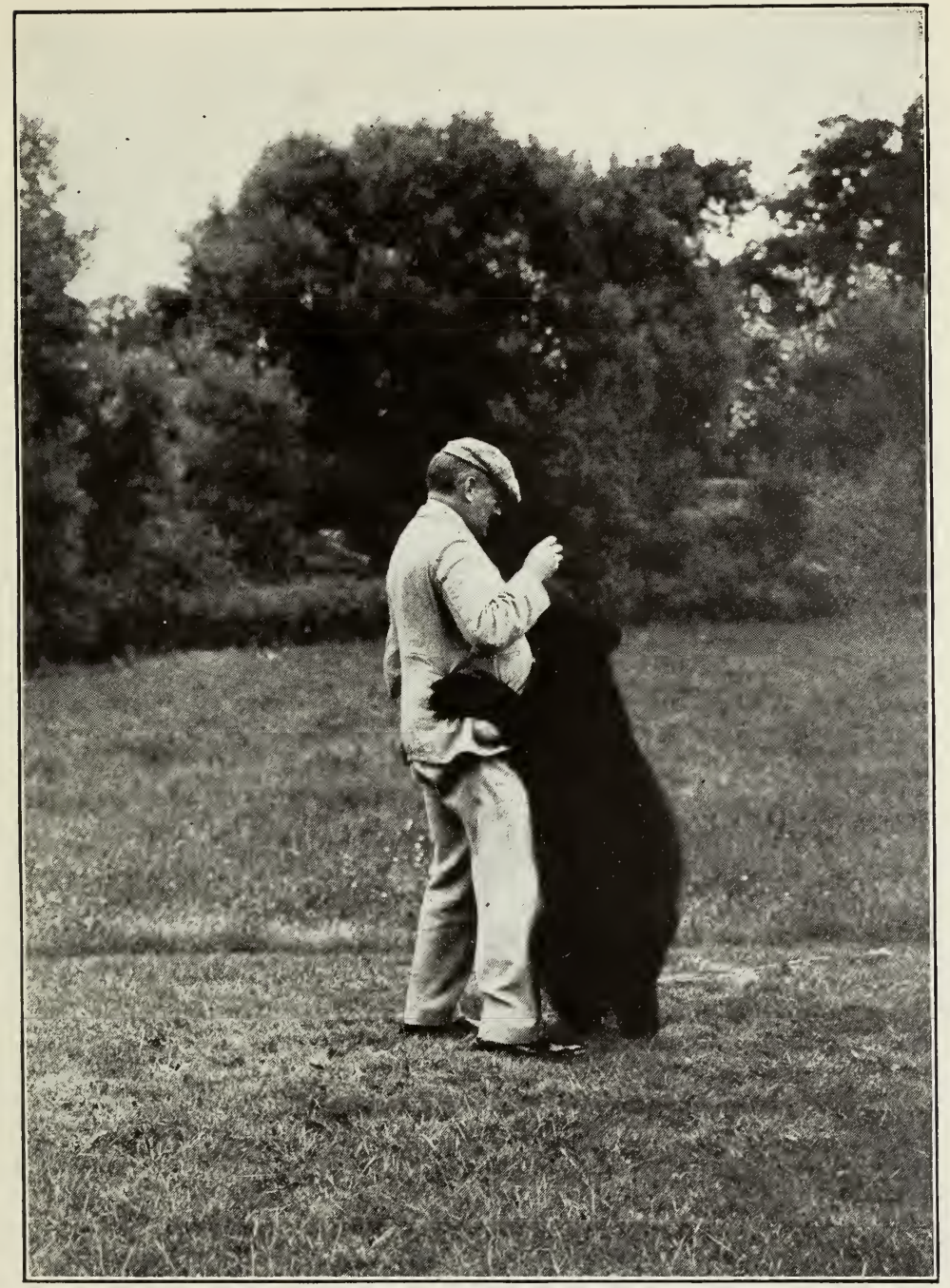

He threw his arms round my waist and drew me closely to him. A moment after this picture was taken, a sudden rage seized Bruno and he nearly put an end to the story 

The bear was now getting so large that it seemed best to have him a little more under restraint. By this time he had grown enough to fit the collar that in his infant days I had bought for his use. He made no objection to wearing it, but he did object most strenuously when I tried to lead him about by a long rawhide strap. All went well when he wanted to go in the same direction that I did, or when he led the way and I followed after. If he did not care to follow me, he simply dropped on the ground and would not budge. If I pulled on the strap, he rolled and tumbled, cursed and swore, and bit and scratched at the rawhide.

The only way to move Bruno now was to "press the button" - to touch that vital spot, his tail. This never failed to start him off on another tack. Through this stratagem, supplemented occasionally by the judicious use of a small riding-whip, together with an unlimited amount of patience, I finally managed to train him to the leash.

About this time Foxy gave us somewhat of a surprise. She became the proud mother of eleven nondescript puppies - all doing well, with mother as bright and cheerful as if she had not a care in the world. When the youngsters grew old enough to walk about, they all went to call on the bear.

Bruno's attitude toward the children of his friend was very kindly, and the little fellows were 
not at all afraid of him. For a long time the bear sat very still, solemnly regarding them with the greatest interest as they tumbled about his feet. Meanwhile Foxy, standing outside the cage and looking through the bars, was not enjoying the show. She whined and pawed at the door, trying to get in, and when Bruno began to handle her children, she became greatly excited.

With his big paw, very carefully, the bear drew up one of the chubby little ones for close inspection. Gently he nosed it over and rolled it slowly about on the ground. Several other puppies had passed a similar inspection, when I opened the cage door and Foxy jumped in. There was no discussion whatever in regard to the situation; the dog had no comments to offer. Very quietly and with great dispatch, she carried her offspring, one by one, by the back of the neck, to the door of the cage, and dropped them outside.

Now that Bruno had grown to such generous proportions (he weighed one hundred and twenty pounds in September and stood five-feet-three in his bear feet), we did not care to have him come in to the house. His parlor tricks were rough and boisterous, his free-and-easy manners inappropriate. He was like a bull in a china shop. His attitude toward furniture was especially crude; if a Chippendale chair chanced to be in his way, he 


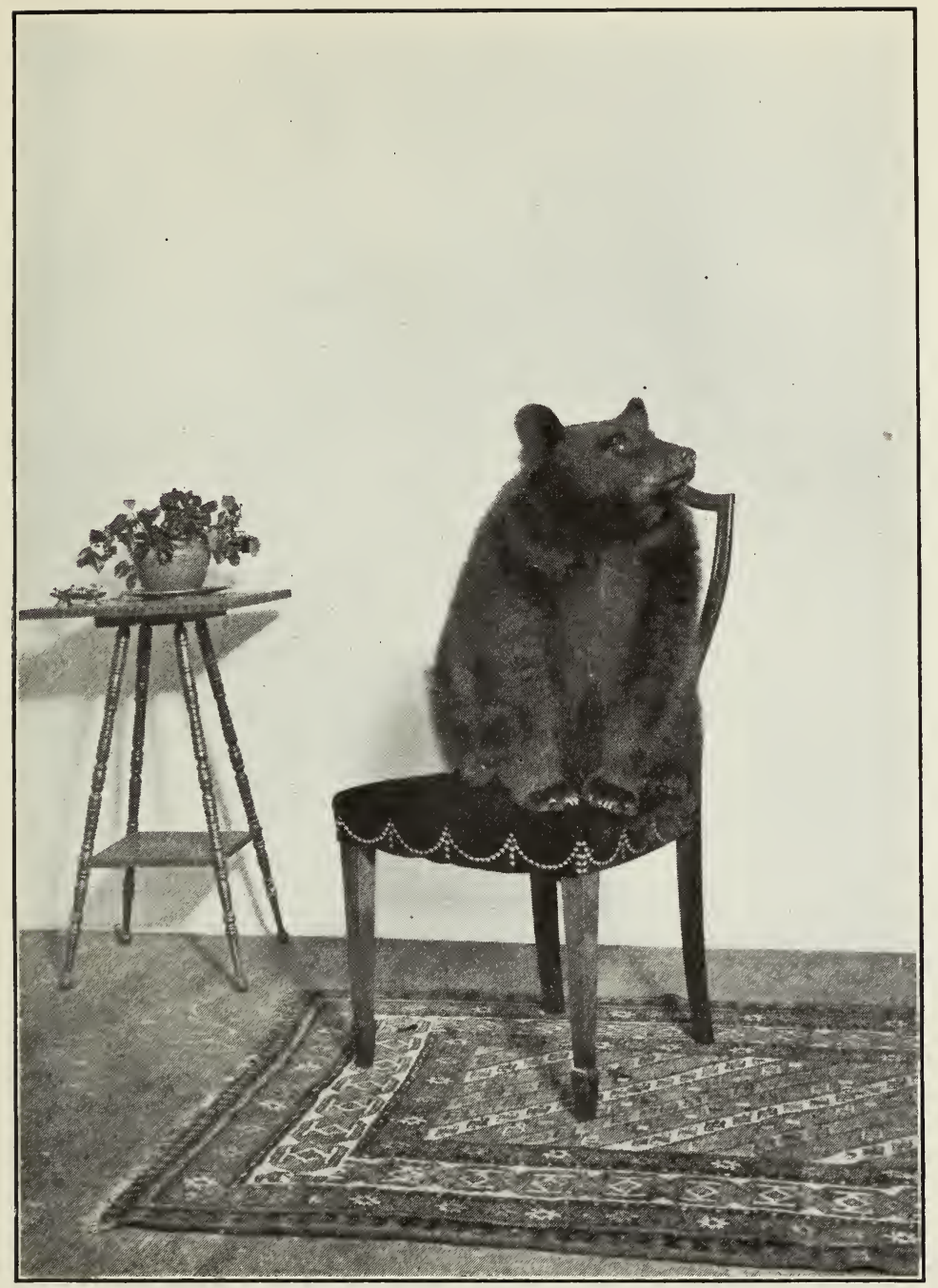

He had evidently come for an afternoon call and was now waiting for tea to be served 

never walked round it, but went through it or over it. To him it made no difference whether a chair had two, three, or four legs.

Imagine then my consternation one afternoon when I saw him bound into the front hall through the door, which had inadvertently been left open. I rushed after him, to save the furniture, or pick up the pieces and clear away the wreck. At first he could not be located. Everything was in order nothing broken, and all quiet. Presently a glad shout of relief from Comrade brought me to her side. There, comfortably ensconced in a velvetseated chair, sat our friend Bruno. He had evidently come for an afternoon call and was now patiently waiting for tea to be served. For his gentlemanly behavior on this occasion I rewarded him with three figs and a small bunch of raisins; then, politely and cautiously, I showed him the door.

Our cook was very fond of Bruno. The bear always relished the food that she gave him, and often accepted her invitation to come into the kitchen. On one of his visits, when cook's attention was elsewhere, he slipped into the pantry. Not since the days of his childhood, when he reveled in the sugar-barrel, had he sniffed such delicious odors. A big brown jug of molasses was conveniently at hand. He slid it out from under the shelf, lapped up the sweet brown sugar that 
had crystallized round the cork, then pulled the stopper out and thrust his long pink tongue deep into the neck of the jug, till it caught the flavor of the molasses down below.

Cook discovered him just in time to prevent a catastrophe. A moment later and the jug would have been pouring its contents out on the floor. Already he had tipped over a pitcher of cream, and pulled several pots and pans from their position on the shelves.

"Get out of here, you black rascal!" cried the mistress of the kitchen; and to emphasize her demand, she belabored Bruno's hind-quarters with the flat of her broom, as, licking his chops, he galloped through the door.

Bruno spent the greater part of his second Belmont winter in his retreat beneath the ground, coming out for food only when the days were warm. If for any reason I wished to see him, however, I had merely to say: "Foxy, go fetch him," and the dog soon dragged the drowsy sleeper, yawning and protesting, up into the light of day.

Early in the spring, as the days grew warmer and the frost was leaving the ground, there came a morning of great excitement. Bruno dug out of his retreat. The thawing earth near the entrance to his den had slipped away and left a small opening beneath the foundation of the cage. Through this 


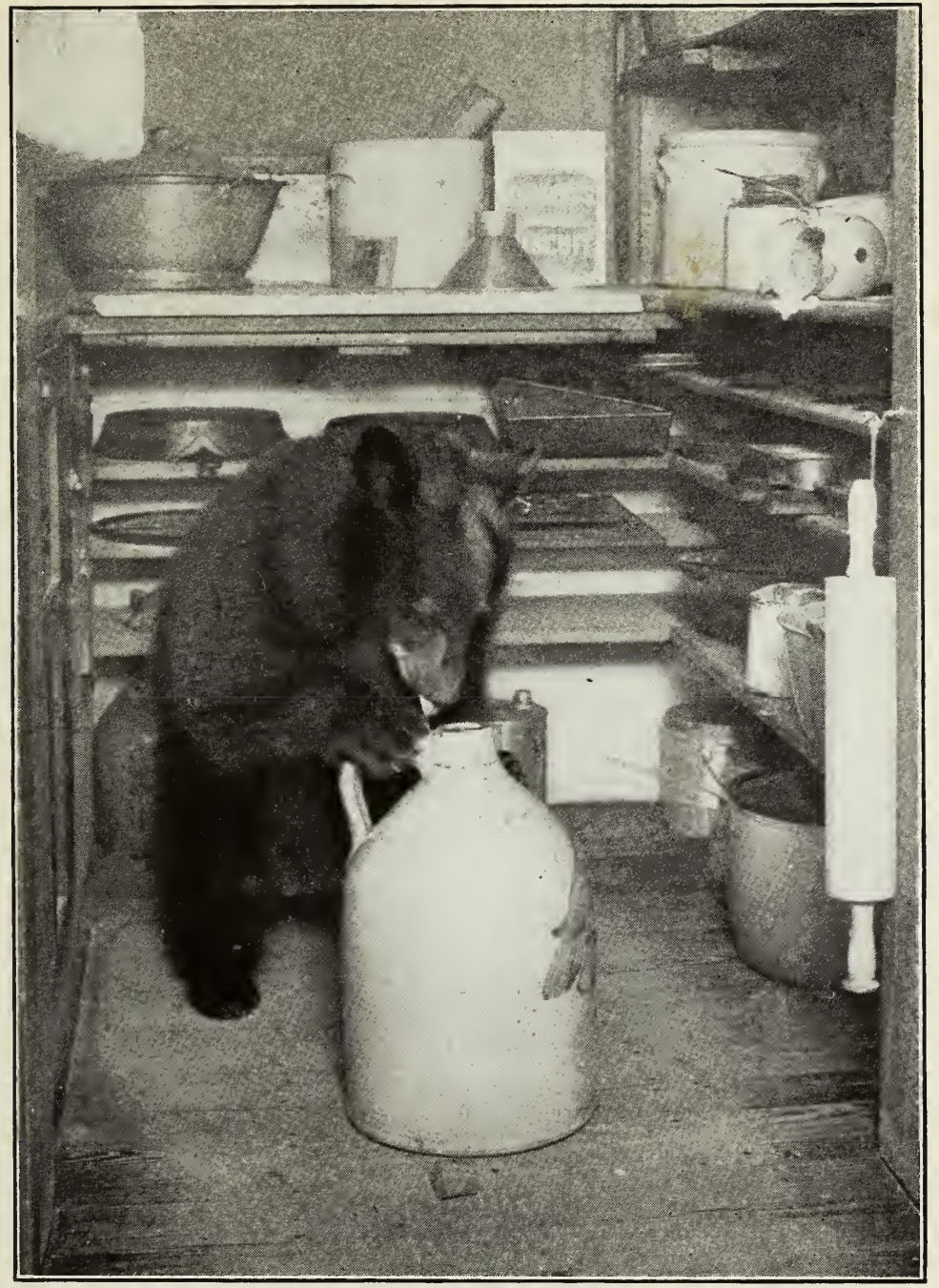

Not since the day when he reveled in the sugar barrel had he sniffed such delicious odors 

hole, which he had easily enlarged, the bear had made his escape. This news came to me over the telephone, and Mrs. Underwood, who talked with me, concluded by saying: "Please come home at once; we have found him. He's in Bessie's kitchen and we can't get him out."

This last information made me feel much easier, for Bessie was our very good friend and neighbor. She knew the bear, and her children had often played with him when he was a cub. Just how long the bear had been at liberty, no one could say; but about eleven o'clock he had made his appearance at their kitchen door. The cook, who was new in her position, heard a noise on the back porch, and, on opening the door to see who was there, discovered, to her amazement and dismay, a big black beast trying to get into a small refrigerator that stood close at hand. With a shriek she slammed the door behind her; but it failed to latch, and a moment later the bear entered the kitchen. Imagine the state of mind of that new domestic on this her first day of service in a strange home! With a wild scream of terror she fled, and left the beast in full possession. This time, however, she was careful to latch the door as she departed. All out of breath, she flew at once to her mistress and hysterically told her story.

Fortunate it was for me that Bruno had chosen 
the home of our friend for his visit, for Bessie did not fear the bear, and knew that, if he were allowed to have his own way, there would be no trouble. Bruno did not want to leave that kitchen, so there he was allowed to stay until my return. Then, with my pocket filled with figs and with the long strap attached to his collar, I coaxed and led him back to his cage.

Not long after that incident Mrs. Underwood was quite astonished when little Alice came running up to her exclaiming, "O Aunty, I have just licked the bear!"

"No, Alice, you should n't say 'licked'; you should say 'whipped.' That was a very naughty thing for you to do," Comrade admonished her.

"No, I did n't whip him, Aunty," Alice replied, "I licked him. I had my face against the cage, and he reached up and licked my cheek with his tongue, and then I licked the side of his nose with my tongue."

Comrade was horrified. How easy it would have been for Bruno to have bitten off the end of that tongue! What a delicate morsel it would have made for him! I shuddered to think what might have happened, and I also began to realize the possibility of some future accident. In spite of his unusual bringing up, my pet was a bear, inheriting all the traits and characteristics of his wild ances- 


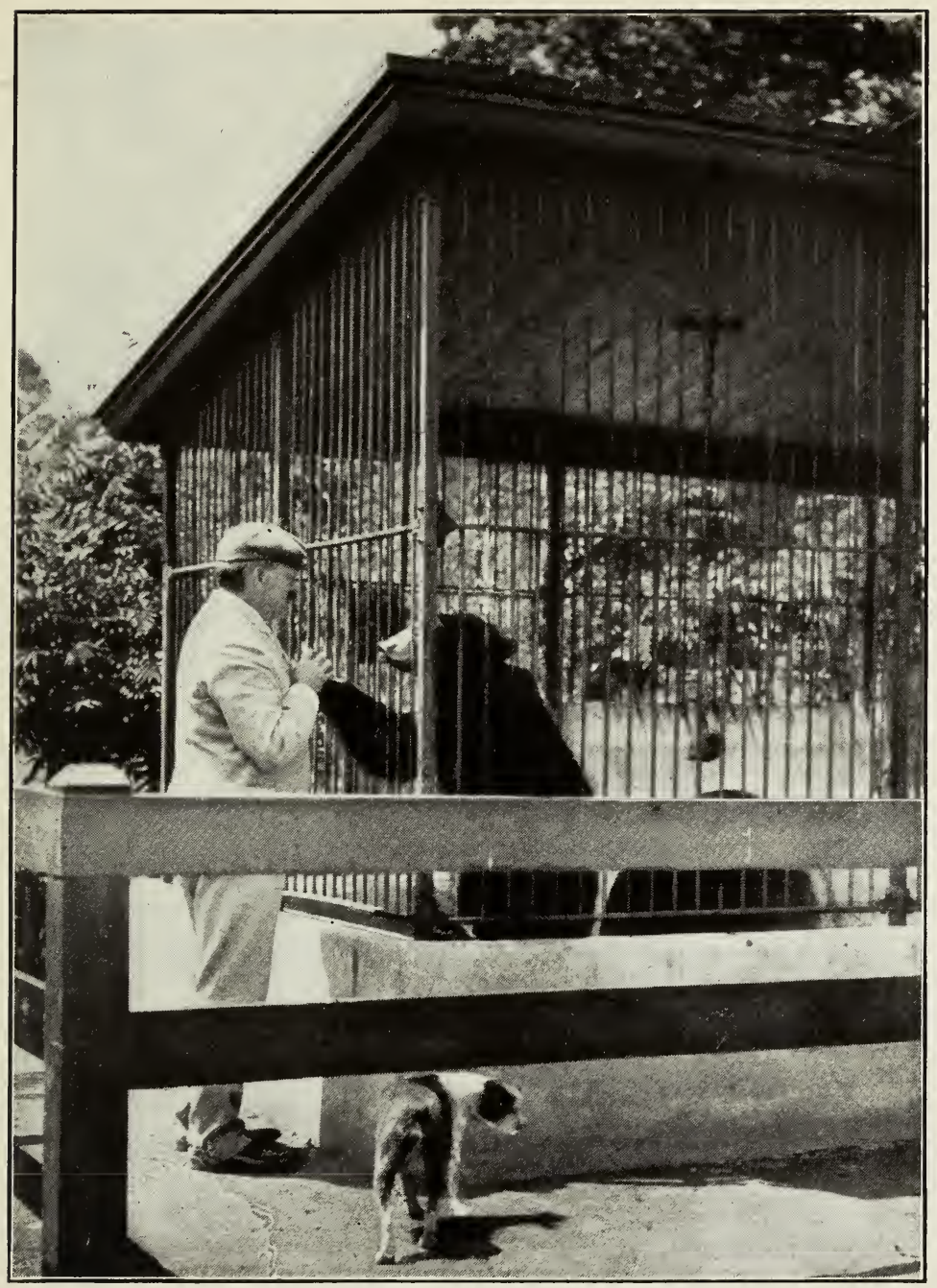

He was glad to see me and touched my arm in greeting 

tors. As far as I had been able to learn, his disposition was no better than that of any ordinary black bear. It is a well-established fact among people who have tamed or handled animals that the North American black bear is sometimes a treacherous fellow and not to be trusted. Another fact worthy of some thought was that the so-called dangerous wild animals, when taken as cubs and brought up as pets, never have the fear of human beings that animals in their natural habitat develop. Consequently, when a sudden rage seizes them, they are more likely to do serious damage.

At this time, the spring of 1905 , Bruno tipped the scales at one hundred and forty pounds. $\mathrm{He}$ was as strong as an ox and, had he cared to do so, could have torn a man to pieces in a very short time. Mrs. Underwood thought that I was taking a good many risks and laying myself liable to serious criticism if I kept the bear much longer, and I was somewhat reluctantly beginning to consider the matter of another home for him, when an event happened which caused me to decide definitely that he must go.

Wishing to take a photograph of Bruno that would show his size at that age (two years and four months). relative to that of a man, I asked a friend of mine if he would be willing to stand beside the bear for that purpose. 
His answer to my invitation, "Not on your life!" was emphatic and disappointing. He was willing, however, to assist me in any way that involved no danger to life or limb. To this end he suggested that $I$ stand beside the bear while he tried to take the picture. He admitted freely that he knew nothing about my camera, but he declared that he knew Bruno well enough to keep away from him.

The details of the episode having been arranged, I took my stand beside the bear and with a gentle voice asked him to stand up. Bruno obeyed instantly and did more than I asked of him. He threw his arms joyously about my waist and drew me closely to him.

"This is all so sudden, Bruno!" I ejaculated. "Stand off a bit and give me space to breathe."

With that he hugged me even closer, and as if to make doubly sure of the prize that he held in his arms, he seized me firmly in his mouth, gripping me by the front of my jacket.

"When shall I take it?" shouted my friend.

"When it looks interesting," I panted in reply.

"It looks pretty good to me right now!" he exclaimed, as he pressed the button.

I have always wished that he had waited just a moment more, for an instant later my jacket, under the exigency of the occasion, began to split up the back; nor did it stop until the rent extended to a 
point between my shoulder-blades. And now the scene grew more animated. Our little play was changing from comedy to tragedy. The bear began to dance and whirl me round and round. He bent me backwards. He pushed me violently from side to side. Oh, how I wish I had known at that time the steps of the weird and wriggly dances of to-day!

But Bruno's ragtime demonstration gave me no enjoyment. His claws were setting into the flesh of my back. I was growing tired and anxious. Vainly I requested that we sit down and rest a while. But no, it was on with the dance, and away we whirled. Intermittently I caught glimpses of Mrs. Underwood anxiously watching my efforts from a vantage-point on the piazza. Her face grew longer and longer with my every revolution.

Awkwardly I missed step, and one of Bruno's heavy paws came down upon my foot. Backward I fell on the grass. The bear on top kept firm his hold upon his partner, and right there, as far as I was concerned, this story was near its end. Bruno was beginning to lose his temper. He would not let me get up. I tried to choke him off; but the harder I gripped his throat, the more he growled and shook my jacket, and the tighter he squeezed me in his arms. Oh, why had n't I taken the advice of my friends and sent him away long ago ?

Suddenly, at this critical point, the fates were 
kind to me. Through all these distressing moments Foxy, the dog, had been an interested but unobtrusive spectator; but now, just at the psychological instant, she took a hand in the proceedings. Barking with excitement, she rushed forward, and with a bound she made once more her famous football play, and, tackling the bear by the tail, held on like grim death.

The day was saved. The game was over. Lame and sore, I rose slowly from the ground. Right then and there in family council it was decided definitely that Bruno must depart. 


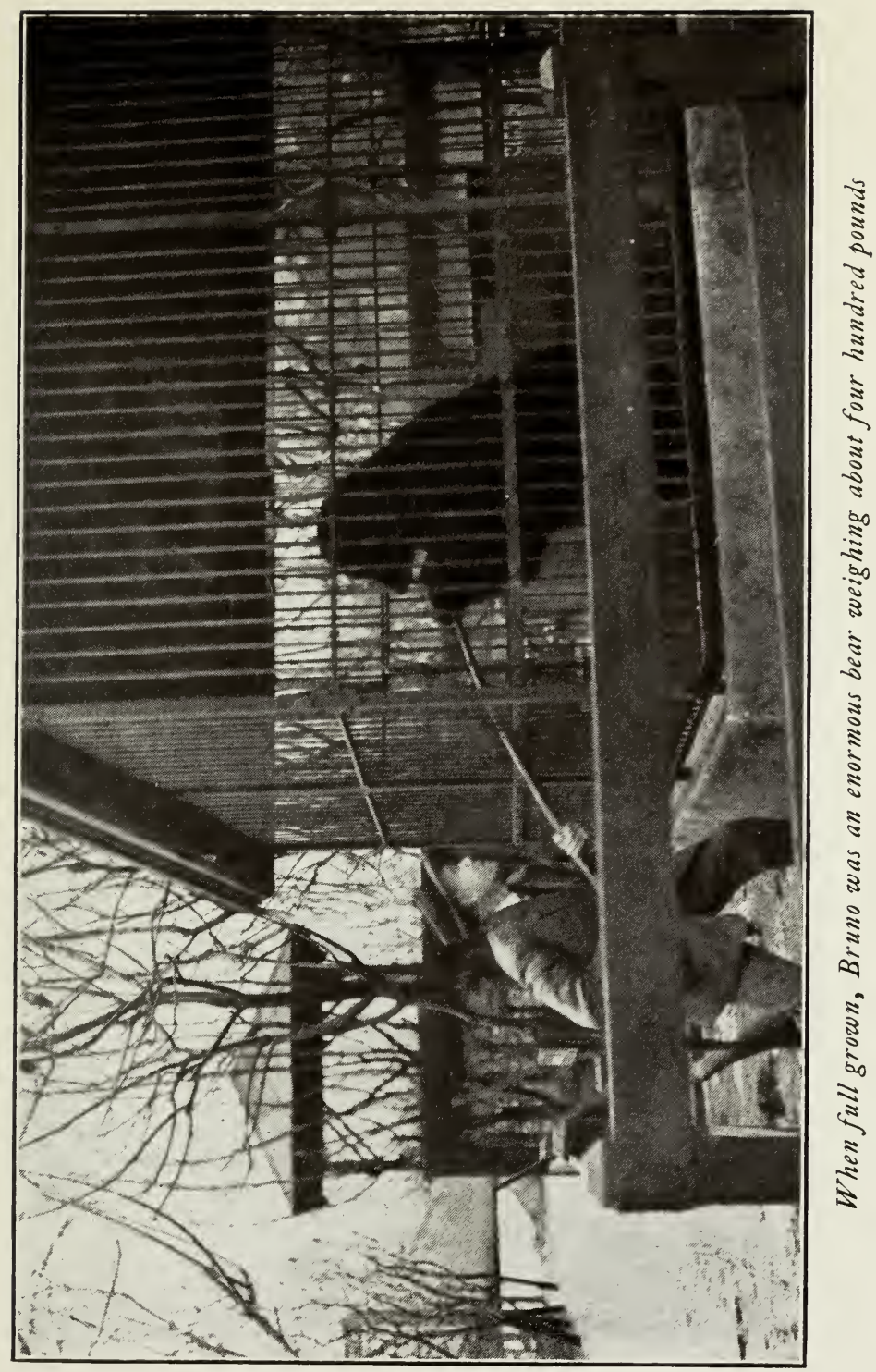





\section{CHAPTER VIII \\ THE END OF THE TRAIL}

THE decision to send Bruno away having been made, I immediately set about finding a suitable place for him. Fortune favored me again, as it had several times before in connection with the bear. Within a week an ideal new home for Bruno had been found. Not far from Belmont is situated one of those large metropolitan reservations which has helped to make Boston so famous for its beautiful park system. Here, under the care of the Commonwealth, near the shore of Spot Pond, a small Zoo is maintained.

It so happened that, just at the time of my difference with Bruno, the bear of this collection died. The roomy cage in which he had lived was equipped with a bathing-pool; its floor was of cement, and there was a fine commodious den for winter use. The director of the Zoo, who was delighted to have a new tenant for his bear-house, received Bruno with open arms. We had some difficulty, however, with his transportation.

The men came to get him in one of the park wagons, and brought with them a large packingcase, in one end of which was a sliding door. It was Bruno's dinner-time, and I placed his food in the 
box and put the open end just inside the cage. Figs and raisins were on the menu that day, and the bear was eager to taste them. As soon as he was well inside, I slid the door shut behind him.

In an instant Bruno seemed to realize that something was wrong. The boards on one side of the packing-case had been left an inch or two apart. Through one of these openings the bear's nose and upper canine teeth suddenly appeared. There was a crunching sound and the splinters flew as Bruno's powerful jaws, working like a huge pair of shears, cut their way through the thin spruce board. With a stick I tapped him on the nose; but he kept at work, and soon would have been at liberty, had not other and newer boards been nailed on the box to cover all the openings.

Hammer in hand, with nails and several spare boards ready for instant use, I stood in the wagon beside the packing-case until we reached the reservation. During the hour that it took for our journey the bear was gnawing and scratching at the side of the box where the openings had been. Whenever there seemed to be any evidence that he was breaking through, I pounded the spot mightily with the hammer.

Bruno entered his new home on the run. Several times he rushed like mad around the cage. Then he became more quiet and began a tour of 


\section{THE END OF THE TRAIL}

inspection, investigating every nook and corner, sniffing and snuffing as he walked about. He went half-way in to the den, and then backed out. $\mathrm{He}$ put one paw very cautiously in to the water of the pool, withdrew it, and shook it dry. On the whole, his new abode seemed to suit him very well.

With feelings of both relief and regret I said good-bye to my pet. The problem was solved, and I had no further occasion to worry about the bear. A happy future was assured for him; amid pleasant surroundings his life would be passed in comfort.

Bruno was not one of those restless caged animals that forever pace pathetically to and fro in their place of confinement. His had always been a life of considerable restriction, and he had become accustomed to it. As long as there were people about and his meals came regularly, he would be contented.

As the Zoo was only a short distance from my home, it was easy for me to drop in now and then and call upon my old friend. For years Bruno never failed to recognize me, and always seemed glad when I came. He would run to the end of the cage, put out his paw between the bars, and touch my arm in greeting. When Bruno was full-grown he was an enormous bear; standing on his hindlegs, with head erect, he measured a little over six 
feet. He must have weighed something more than four hundred pounds. Though he was never put on the scales after he left Belmont, his size and weight could be estimated approximately by comparing him with other animals whose weight was definitely known.

I took the last photograph of him when he was seven years old. At the time he was playing with a rake-handle held by a friend of mine, a man of average height. It will be seen by comparing the two figures in the picture that Bruno was an animal of prodigious size. As he grew older, I went to see him less frequently, until, during the latter period of his life, I seemed to grow out of his recollection.

With his keeper, a man who had a special aptitude for handling animals, Bruno was a great favorite. But, notwithstanding the fact that he recognized this man as his master and seemed to have a fondness for him, there came a day when the circumstance that I had been warned against happened. The keeper was cleaning the cage, and was using a broom and a shovel. The latter he had left on the floor, while he employed himself with the broom. Just as the man was finishing his work, Bruno picked up the shovel and began to play with it. Being in a hurry, the keeper grasped the handle and violently jerked it away. In a flash 
the bear lost his temper and turned upon him. Then, with one smash of his powerful fore-arm, he felled him to the floor and, springing with a savage growl upon the prostrate man, set his wicked teeth through the fleshy muscles of his arm just below the shoulder.

In telling me about it afterward, the keeper averred that it was his own fault. He had always allowed the bear to play with the tools when he was not using them. "Why," he explained, "he would have had me dead in a minute if he had a wanted to! He was just like a boy that's been teased. $\mathrm{He}$ only give me one lick and a bite for disturbing him. I got to my feet, picked up my things, and walked right by him. He stood close beside the door when I went out, and he never offered to touch me again. I was only laid up for two days, and I don't hold it against him."

In July, 1917, when Bruno was fourteen years old, he suddenly became paralyzed in his hindquarters, and a few days later, apparently without any suffering, he passed away. Black bears have been known to live in confinement to an age of twenty years, but fifteen years is probably about the average length of their existence. Just how long a wild bear usually lives under natural surroundings out in the open, it is hard to state, for 
there is no way to obtain any positive data.

Here in New England, where each year a host of hunters and trappers are roaming through the forest, Bruin's life is not an easy one. Every man is his enemy. I have talked with many hunters, and the general opinion seems to be that wild bears of this region seldom reach an age of more than five or six years. By that time they have either been shot or caught in traps. Bruno's life had been one of ease and comfort, free from the strife and tragedy that is usually the lot of his wild brethren of his native woods.

Our bear had gone, but the memory of him was destined to live for many years to come.

In spite of many willing hands that reached out to help, things went badly with the Weldons. The injured foot grew worse, and after a year of suffering, Mr. Weldon went to a hospital and had an operation performed. This afforded some relief, but no permanent cure, and he was incapacitated for the greater part of the time. It was a constant struggle for the brave little family to keep their heads above water. Twice within three years they were obliged to change their home. Though they did not let me know of their straitened circumstances, I was fortunately able, through the aid of friends in Maine, to keep informed with regard to them. 
From time to time I forwarded gifts of money, telling Mrs. Weldon whence they came and explaining to her how the funds had been intrusted to me for her benefit. A year later the Weldons moved for the third time, and this change took them a long distance from their last abode, quite out of touch with the region about my camp. For a long period I heard nothing about them, until,

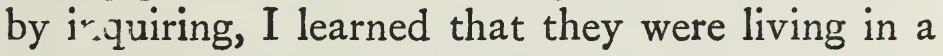
small town, some fifty miles away from their former home.

In order to get into communication with them again, I wrote to a provision store in the place, to see if by chance the Weldons traded there. It so happened that they did, and the grocer knew them well. Though he spoke in the highest terms of their integrity and worthiness, he had a pathetic story to tell of their efforts to keep the wolf from the door. This merchant was a very fine man, whose heart was in the right place. A plan was soon arranged whereby the family could have whatever they needed from his store, and never know who was connected with the scheme.

Mr. Weldon's foot had grown much worse again, and instant relief was necessary or he might lose his leg. Immediate arrangements were made and a date was set for his coming to the Massachusetts General Hospital in Boston, when I received a 
letter from Mrs. Weldon which read as follows:-

It has just come to my knowledge that our grocer has been begging of you in our behalf. I did not know anything about this. I think it is a great impertinence and I am ashamed to think that such a thing was done after all the Christmas boxes and the checks at Christmas time that have been sent us. Last fall he wanted me to write and ask you to help us; but I told him that I had no claim on your bounty, and that I would not hear of any such a thing.

I trust that you and Mrs. Underwood will not think badly of me and mine as your help was asked without our knowledge. I hope that you will see $\mathrm{Mr}$. Weldon when he comes to the hospital, and he will be able to tell you all of the circumstances, and apologize for such an affront to you. The children and I are all well and very, very grateful to all our friends.

On receipt of this letter I wrote a reply in which I explained that she was mistaken about the grocer asking me to help - that he had merely answered my own request for information. I assured her also that I should certainly see Mr. Weldon at the hospital both before and after the operation, and that I could keep her closely in- 


\section{THE END OF THE TRAIL}

formed about him, since one of the surgeons was a friend of mine.

Mr. Weldon spent a month in the hospital in Boston, and the surgeons felt that the operation had been successful. During his convalescence I took him one day to the Fells Reservation, to call upon the bear. As we walked about among the cages, I so managed that we came on Bruno's quarters suddenly. The bear, as we stopped in the path directly in front of his cage and only a few feet away, was standing on his hind-legs at his full height.

"That can't be Bruno!" exclaimed Weldon, as he gazed in wonder at the huge beast. Then, addressing the bear, he soliloquized: "When I saw you last, you was a little cub and only weighed eleven pounds. My God," he added in a husky awe-struck voice, still speaking to the bear, "when I think of what you was in my family and what you have done for me and mine! Great Heaven, ain't it wonderful, Mr. Underwood," he said to me, "how this thing has turned out?"

A week later I received this characteristic letter from the friendly grocer:-

I went to the stable at 4.30 this morning, to feed my horse, and on my return I noticed a familiar smile playing around (or nearly around) the 
summit of a tall slim pedestal which was standing on my store platform. In other words, Mr. Weldon landed here this morning feeling O.K., and loud in his praises of the manner in which he had been treated by all you good people. And now, if you come to Maine in the near future, as Mr. Weldon tells me you propose doing, can't you spare me a few days of your time? We are rough country people, but we are clean and our roof don't leak. I can offer you something to eat every day and a decent bed to sleep in, and while I can't offer you much in the way of entertainment, I would be mighty glad to see you, and will gladly do all I can to make your stay pleasant.

Trusting that I may soon have the pleasure of seeing you, I am

Very truly yours.

I never had the privilege of meeting this kindly grocer, but I am sure that I should like him; we had found a common interest in the welfare of the Weldons.

During that summer I heard nothing from the family, but my merchant friend in answer to a letter of inquiry from me said:-

Replying to your favor of the 2Ist, I regret very much that $I$ am unable to send you a very 
favorable report regarding the Weldon family. Mr. Weldon's foot, although much better than before he entered the hospital, has never entirely healed, and he has not been able to do much work yet, only a few days occasionally. One of our local physicians has been working on his foot the past few weeks, and Mr. Weldon thinks it is healing gradually and says he is going to start out next week hunting for a situation as cook, but the outlook seems very "dusky" to me at present. Mrs. Weldon and the children are well, and so far have had enough to eat, and I hope your kind donations will be as much appreciated by them as they are by

\section{Yours with kindest regards.}

In November I learned from the local doctor that it had become imperative that Mr. Weldon's foot should have surgical treatment immediately. Another operation was necessary, and once more Mr. Weldon came to Boston. His trouble had now assumed a rather alarming aspect, and in order to check its further spread it was necessary to adopt heroic measures and remove the foot.

Once more the assistance that came from Bruno (indirectly of course) was the means of tiding the family over a difficult period. But after the operation, which was successful to the extent of arrest- 
ing the spread of the trouble, Mr. Weldon was able to work only intermittently.

Persons less courageous than Mrs. Weldon would have given up the fight, for the odds were all against her. In the years that had passed since she had saved the life of the cub, her own family had increased in number, until there were five girls and two boys. To clothe them, feed them, bring them up properly, and care for them in sickness, was a task that would have driven to despair many women in far better circumstances. But this woman of the kind heart had the blood of the pioneers in her veins. She would not give up the struggle. When the family funds dwindled to the vanishing point, she found outside work that enabled her to purchase the bare necessities of life.

And so she has toiled, year after year, ever cheerfully, against tremendous difficulties - and never once has asked for help. The great reward of her labors has been the bringing up of a fine family of sturdy children, who are a credit to her name.

It has ever been a surprise to her that the bread she cast upon the waters so long ago has returned to her again and again; it seems little less than a miracle that, many years after she took the little starveling to her breast, persons of whom she never has heard should wish to reward and commend her simple act. 


\section{THE END OF THE TRAIL}

Only last year I received a letter from Mrs. Weldon that touched me deeply. A few lines from it will show - better than any words of mine her indomitable spirit:-

This has been a hard winter, but I have had steady work in a shop at sixteen dollars a week (when I get a full week), so I have been able to get along very well with what extra work I could do evenings. I have been well all winter, but two of the children have had the mumps, which kept them out of school for a while. Ursula has had the La Grippe this spring, but is better now. I have five children at home, including my baby who is four years old. Mr. Weldon has not been able to get out-doors at all since last Thanksgiving. And now I think I have told you all. The children are in good health, are not hungry and are warm. We all have much to be thankful for.

Your very grateful friend,

K. W. WELDON

Eighteen years have passed since my midwinter trip into the woods of Maine, to verify an almost unbelievable story heard by chance. Little did I think at that time how it was to influence vitally the lives of a large family. That journey not only proved the unusual story to be true, but also gave 
me far more than the truth that I had sought. I discovered and eventually acquired Bruno, as entertaining and surprising a pet as man ever possessed; but my greatest discovery was an unusual example of compassion that I like to believe reveals the natural, untutored kindness of the human heart - a discovery that is refreshing in an age that has had its fill of hatred and bitterness.

\section{THE END}



MCGRATH-SHERRILL PRESS

BOSTON 


GETTY CENTER LIBRARY 


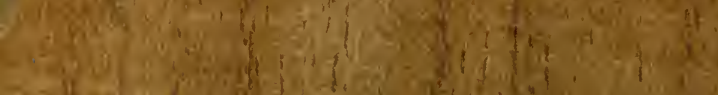

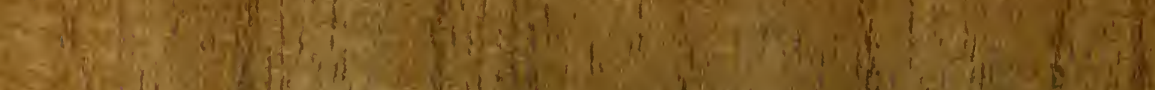

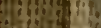

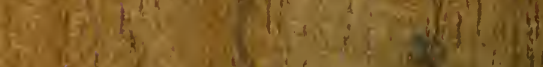

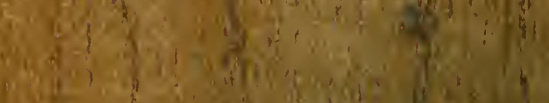
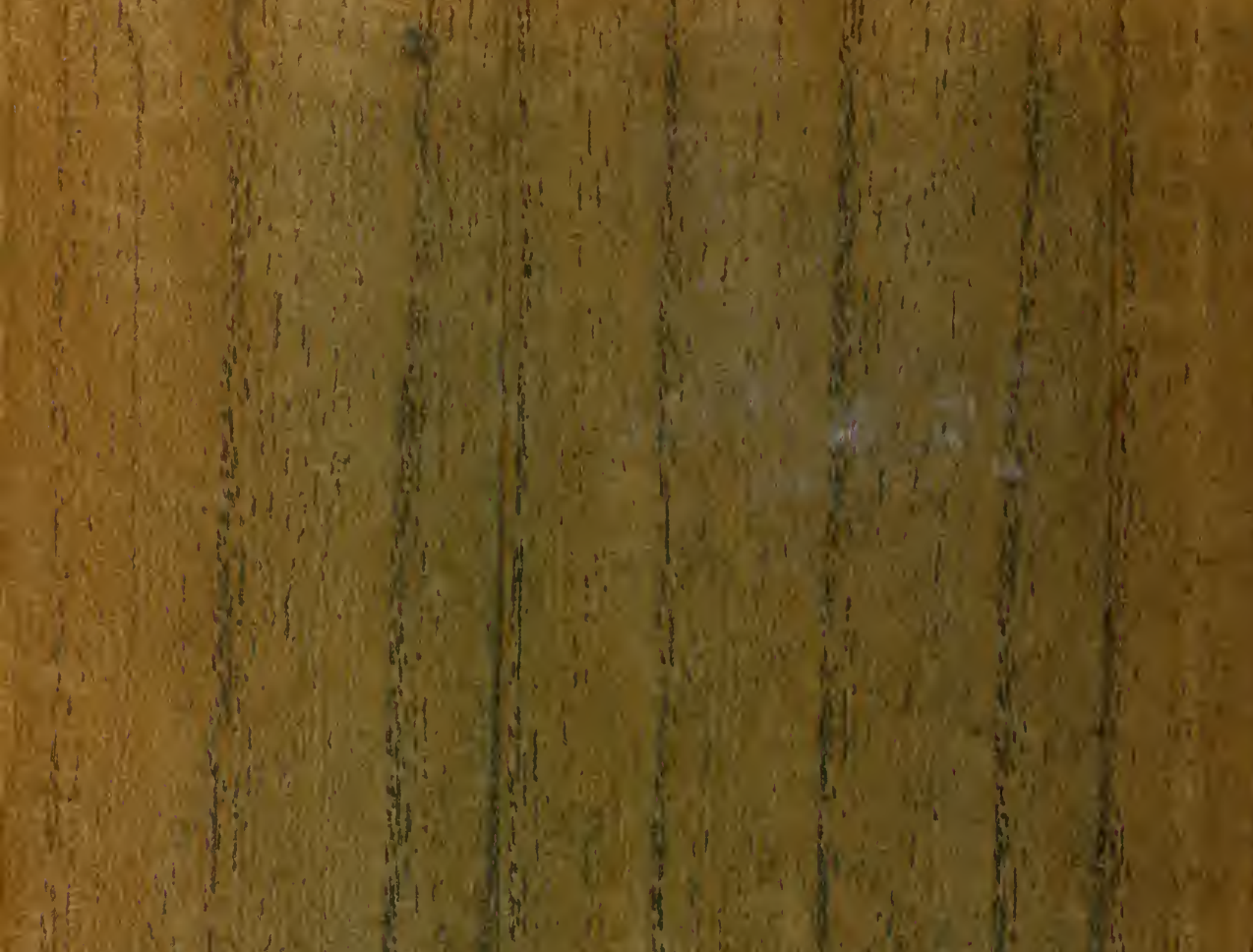

aif

whitis is

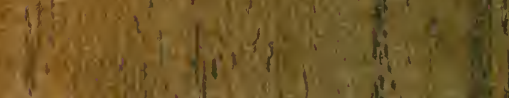
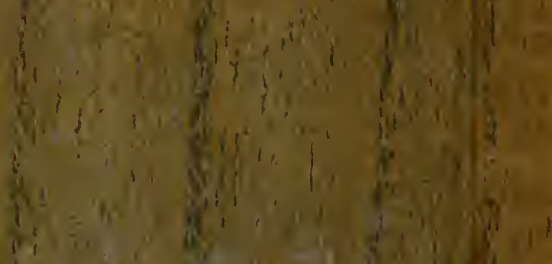
wor 7 is on encon 3iff in

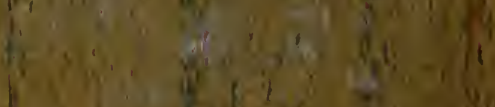

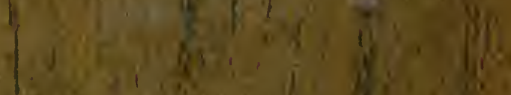

fif 4. Pin $(102)$ 47

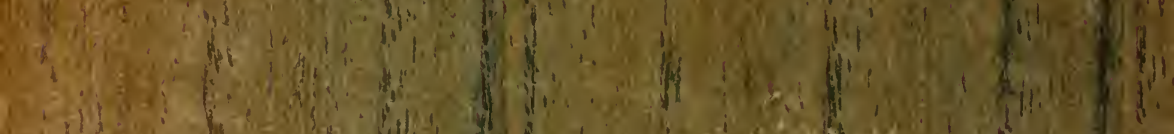

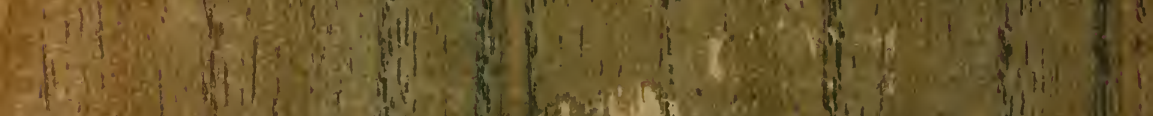

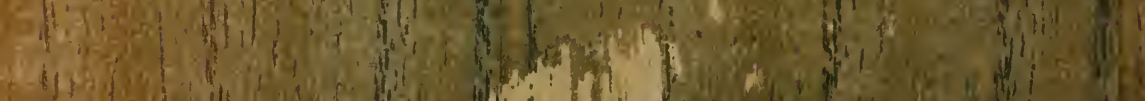

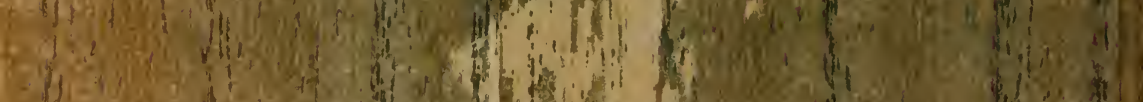
Hidy

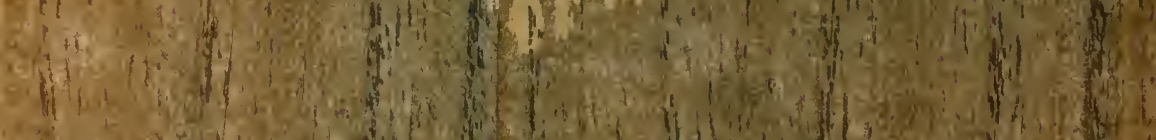

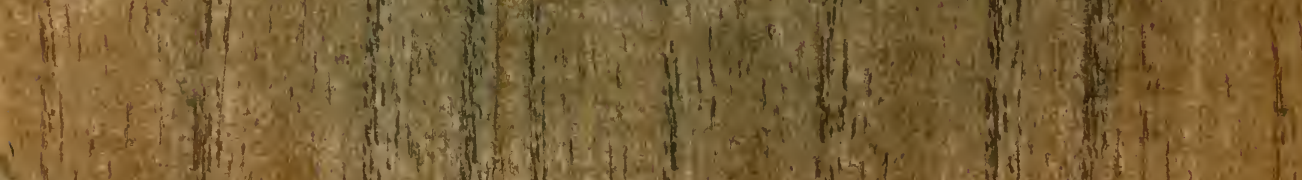

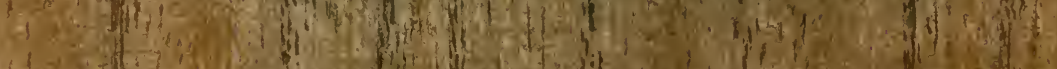

